Ediguer Enrique Franco Guzmán

\title{
Medição de Propriedades Viscoelásticas de Líquidos por Ultrassom
}

\author{
Tese apresentada à Escola Politécnica \\ da Universidade de São Paulo para \\ obtenção do Título de Doutor em \\ Engenharia.
}


Ediguer Enrique Franco Guzmán

\title{
Medição de Propriedades Viscoelásticas de Líquidos por Ultrassom
}

\author{
Tese apresentada à Escola Politécnica \\ da Universidade de São Paulo para \\ obtenção do Título de Doutor em \\ Engenharia. \\ Área de concentração: \\ Engenharia de Controle e Automação \\ Mecânica \\ Orientador: \\ Prof. Dr. Flávio Buiochi
}




\section{Ficha Catalográfica}

Guzmán, Ediguer Enrique Franco

Medição de Propriedades Viscoelásticas de Líquidos por Ultrassom/ E.E. Franco. - ed.rev. - São Paulo, 2010.

$95 \mathrm{p.}$

Tese (Doutorado) - Escola Politécnica da Universidade de São Paulo. Departamento de Engenharia Mecatrônica e de Sistemas Mecânicos.

1. Elasticidade do fluxo dos líquidos. 2. Viscosidade do fluxo dos líquidos. I. Universidade de São Paulo. Escola Politécnica. Departamento de Engenharia Mecatrônica e de Sistemas Mecânicos. II. t. 
À minha esposa e familia.

A Ernesto Sábato... por ter abandonado a ciência. 


\section{Agradecimentos}

Agradeço a meu orientador Prof. Dr. Flávio Buiochi pelo acompanhamento e apoio no desenvolvimento deste trabalho.

Ao Prof. Dr. Julio Cezar Adamowski pela sua ajuda e conselhos que foram de vital importância.

Ao Prof. Dr. Tokio Higuti pela sua colaboração.

A todos meus colegas do Laboratório de Ultrassom do Departamento de Engenharia Mecatrônica e de Sistemas Mecânicos da Escola Politécnica da USP.

À CAPES pela bolsa de Doutorado e à FUSP pelos recursos financeiros para a aquisição de materiais.

Ao povo brasileiro em geral, por fazer a minha permanência neste pais tão agradável.

Finalmente, o contato com a língua, a arte, a comida e os lugares paradisíacos do Brasil representa para mim um ganho cultural que não pode ser medido e sou muito grato por isso. 


\section{Resumo}

A medição das propriedades viscoelásticas de líquidos por ultrassom tem sido um tema de pesquisa importante desde meados do século XX, principalmente, pela possibilidade de realizar medições em tempo real da viscosidade. $\mathrm{O}$ método de medição baseia-se na determinação do coeficiente de reflexão complexo (magnitude e fase) de ondas de cisalhamento refletidas da interface definida entre um sólido e uma amostra líquida. Enquanto a medição da magnitude é relativamente simples e precisa, a medição da fase é muito difícil devido à forte dependência da temperatura, que gera uma incerteza muito grande. No entanto, na medição da viscosidade em regime newtoniano somente a magnitude é requerida. Ocorre que os resultados experimentais reportados até o momento na literatura não coincidem quantitativamente com a teoria. Neste trabalho, uma nova técnica que permite determinar com boa precisão a magnitude do coeficiente de reflexão e, por conseguinte, a viscosidade de líquidos em regime newtoniano foi desenvolvida. Foi mostrado que a maioria dos líquidos testados apresentam comportamento newtoniano à frequência de trabalho de $1 \mathrm{MHz}$, com exceção de alguns óleos automotivos de alta viscosidade, que possuem claramente comportamento viscoelástico. Desvios menores que $12,5 \%$ nas medições da viscosidade dinâmica de substâncias com moléculas relativamente simples, como glicerina e glicose, mostram a viabilidade da técnica. Também é proposto um novo método que permite calibrar o dispositivo de medição para monitorar a viscosidade de um líquido ou grupo de líquidos. Além disso, uma aplicação na monitoração da contaminação da água por substâncias oleosas é apresentada. 


\section{Abstract}

The ultrasonic measurement of viscoelastic properties of liquids has been an important research topic since the mid-twentieth century mainly due to the possibility of real-time viscosity measurements. The measurement technique is based on the determination of the complex reflection coefficient (magnitude and phase) of shear waves reflected from the solid-liquid interface. While magnitude measurement is relatively simple and precise, phase measurement is a difficult task due to strong temperature dependence that induces large errors. However, when the measurement is carried out under Newtonian regimen only the magnitude is required. Nonetheless, experimental results reported in literature until now do not agree quantitatively with the theory. In this work, it was developed a novel technique that accurately and precisely determines the reflection coefficient magnitude and, consequently, the Newtonian viscosity. Most tested liquids showed Newtonian behavior at the working frequency of $1 \mathrm{MHz}$ except for some automotive oils of high viscosity, which showed an evident viscoelastic behavior. Deviations up to $12.5 \%$ in the dynamic viscosity measurement of substances with relatively simple molecules, such as glycerin and corn syrup, show the technique suitability. A calibration method of the measurement cell allowing the indirect viscosity measurement of a liquid or group of liquids is proposed. Moreover, a new application to oil-in-water contamination monitoring is presented. 


\section{Sumário}

\section{Lista de Figuras}

\section{Lista de Tabelas}

\section{Lista de Abreviaturas}

\section{Lista de Símbolos}

1 Introdução $\quad 20$

1.1 Introdução e motivação . . . . . . . . . . . . . . . . . . . . 20 20

1.2 Métodos de medição . . . . . . . . . . . . . . . . . . . . 22

1.3 Estado da arte e trabalhos relacionados . . . . . . . . . . . . . 23

1.4 Objetivos . . . . . . . . . . . . . . . . 26

1.4.1 Objetivo geral . . . . . . . . . . . . . . . 26

1.4 .2 Objetivos específicos . . . . . . . . . . . . 26

2 Bases teóricas do método de medição 28

2.1 Sólidos e líquidos na reologia . . . . . . . . . . . . . . . . . 28

2.2 Tensão e deformação de cisalhamento . . . . . . . . . . . . . . . . 29

2.2.1 Deformação e taxa de deformação . . . . . . . . . . . . . . 29

2.2.2 Relação tensão-deformação . . . . . . . . . . . . . . . 30

2.2.3 Uso do termo "viscosidade" . . . . . . . . . . . . . . . 32

2.3 Propagação de ondas de cisalhamento num meio viscoelástico . . . 32

2.3.1 Módulo de cisalhamento complexo . . . . . . . . . . . . 32 
2.3 .2 Equação de onda . . . . . . . . . . . . . . . . . . 34

2.3.3 Impedância acústica . . . . . . . . . . . . . . . . . 35

2.4 Fenômeno de reflexão na interface sólido-líquido . . . . . . . . . . 36

2.5 Propriedades viscoelásticas do líquido . . . . . . . . . . . . . . 38

2.6 Relações válidas em regime newtoniano . . . . . . . . . . . . . . 38

2.7 Modelos simples para materiais viscoelásticos . . . . . . . . . . . 40

2.7.1 Modelo de Kelvin-Voigt . . . . . . . . . . . . . . . 40

2.7.2 Modelo de Maxwell . . . . . . . . . . . . . . . . . . . . . . 41

2.8 Análise das quantidades mensuráveis . . . . . . . . . . . . . . . 43

3 Metodologia experimental 49

3.1 Células de medição . . . . . . . . . . . . . . . . . . . . . . . . 49

3.1.1 Célula com conversão de modo (CCM) . . . . . . . . . . . 49

3.1.2 Células com transdutores de cisalhamento (CTC) . . . . . 52

3.2 Determinação experimental do coeficiente de reflexão . . . . . . . 53

3.2.1 Técnica da frequência central . . . . . . . . . . . . . 55

3.2.2 Técnica da banda de frequência . . . . . . . . . . 55

3.2.3 Procedimento experimental . . . . . . . . . . . 56

3.2 .4 Análise dos sinais . . . . . . . . . . . . . . . . 58

3.3 Propriedades físicas dos líquidos testados . . . . . . . . . . . 59

3.4 Propriedades físicas do sólido usado na interface de medição . . . 62

3.5 Análise dos resultados experimentais . . . . . . . . . . . . . . 62

4 Medição em regime newtoniano $\quad 64$

4.1 Medição da magnitude . . . . . . . . . . . . . . . 66

4.2 Medição da fase . . . . . . . . . . . . . . . . . . 73

5 Medição em regime não-newtoniano e outras técnicas $\quad 76$ 
5.1 Medição em regime não-newtoniano . . . . . . . . . . . . . . 76

5.1 .1 Óleos automotivos . . . . . . . . . . . 76

5.2 Medição usando dispositivos calibrados . . . . . . . . . . . . . . . 80

5.3 Aplicações com emulsões água-óleo . . . . . . . . . . . . . . . . . 82

6 Conclusões e trabalhos futuros $\quad 86$

6.1 Conclusões . . . . . . . . . . . . . . . . . . . . 86

6.2 Trabalhos futuros . . . . . . . . . . . . . . . . . . . . . . 89

$\begin{array}{ll}\text { Referências } & 91\end{array}$ 


\section{Lista de Figuras}

2.1 Deformação de um elemento retangular submetido a tensão de cisalhamento simples. . . . . . . . . . . . . . . . . . . . . 29

2.2 Formas de ondas da tensão $\sigma$ e da deformação $\gamma$ em regime harmônico. . . . . . . . . . . . . . . . . . . . . 33

2.3 Reflexão de uma onda de cisalhamento na interface entre dois meios de diferente impedância acústica. . . . . . . . . . . . . . . . 36

2.4 Modelos de Kelvin-Voigt (a) e Maxwell (b) para materiais viscoelásticos. . . . . . . . . . . . . . . . . . . . . . . . . 41

2.5 Viscosidade em função da frequência obtida com o modelo de Maxwell para três valores de $G_{\infty}(\mathrm{Pa}) . \ldots . . . . . .42$

2.6 Módulos de armazenamento (a) e de perda (b) obtidos com o modelo de Maxwell para um líquido fictício de viscosidade 1,0 Pas, densidade $1000 \mathrm{~kg} / \mathrm{m}^{3}$ e três valores diferentes de $G_{\infty}(\mathrm{Pa})$, com frequências até $10 \mathrm{MHz}$. . . . . . . . . . . . . . . . 43

2.7 Magnitude (a) e mudança de fase (b) do coeficiente de reflexão em função da frequência, para um líquido fictício de viscosidade 1,0 Pas e densidade $1000 \mathrm{~kg} / \mathrm{m}^{3}$, para quatro materiais sólidos na interface de medição, usando o modelo newtoniano. . . . . . . . . 44

2.8 Magnitude (a) e mudança de fase (b) do coeficiente de reflexão em função da frequência, para três líquidos fictícios de viscosidade 1,0 Pas e diferente valor de densidade, usando o modelo newtoniano e acrílico como meio sólido.

2.9 Magnitude (a) e mudança de fase (b) do coeficiente de reflexão em função da viscosidade, para três frequências de trabalho, usando o modelo newtoniano e acrílico como meio sólido. . . . . . . . . . 
2.10 Valores de magnitude (a) e mudança de fase (b) em função da frequência fornecidos pelos modelos newtoniano e de Maxwell, com três valores diferentes de $G_{\infty}(\mathrm{Pa}) . \ldots \ldots$. . . . . . . . . . 46

2.11 Mudança de fase plotada em função da magnitude para o modelo newtoniano e o modelo de Maxwell, para três valores de $G_{\infty}$. . .

3.1 Células de medição com conversão de modo (CCM): esquema da montagem (a), sinal adquirido (b) e imagem da célula no banho termostático $(\mathrm{c}) . \ldots \ldots \ldots \ldots$

3.2 Célula de medição que usa ondas de cisalhamento geradas diretamente por um transdutor comercial (CTC): esquema (a), sinal obtido (b), imagem da célula aberta (c) e imagem da célula no banho $(\mathrm{d}) \ldots \ldots \ldots \ldots \ldots$. . . . . . . . . . . . . 54

3.3 Arranjo experimental usado. . . . . . . . . . . . . . . . . . 58

3.4 Medição da viscosidade dinâmica $\left(\eta_{0}\right)$ da glicerina em função da temperatura usando o viscosímetro rotacional Rheotest 2.1: curvas de fluxo (a) e resultados de viscosidade (b). . . . . . . . . . .

4.1 Magnitude (a) e mudança de fase (b) em função da frequência para

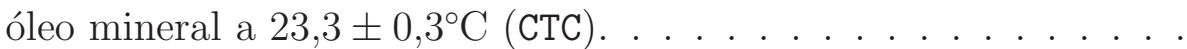

4.2 Magnitude do coeficiente de reflexão, em função da largura de banda (parâmetro $\beta$ ), para glicerina na faixa de temperatura entre

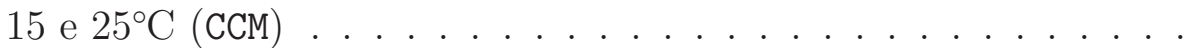

4.3 Magnitude do coeficiente de reflexão, em função da largura de banda (parâmetro $\beta$ ), para a mistura água-glicose de milho para diferentes concentrações de glicose (CCM) . . . . . . . . . . . . .

4.4 Viscosidade medida por ultrassom com glicerina (a) e a mistura água-glicose de milho (b) na frequência central do pulso $(\beta=0) \mathrm{e}$ na banda de frequência com menor desvio $(\beta=0,4)$ comparada à viscosidade medida com o viscosímetro rotacional $(\mathrm{CCM})$. . . . . .

4.5 Magnitude do coeficiente de reflexão $r$ em função da frequência para as amostras da mistura água-glicose de milho e o efeito do cálculo na banda de frequência $(\mathrm{CCM}) \ldots$. . . . . . . . . . . 
4.6 Valores medidos de $r$, para $\beta=0.4$, em função dos valores teóricos de $\left|Z_{L}\right| / Z_{S}$ dos resultados mostrados na figura 4.4 comparados com os valores teóricos fornecidos pelas equações (2.39) e (2.40). . . . . 70

4.7 Magnitude do coeficiente de reflexão (a) e viscosidade (b) em função da largura de banda para óleo mineral a $18,2 \pm 0,2^{\circ} \mathrm{C}$. Resultado de quatro repetições a $1 \mathrm{MHz}$ usando a célula com conversão de modo (CCM). . . . . . . . . . . . . . . . . . .

4.8 Magnitude do coeficiente de reflexão (a) e viscosidade (b) em função da largura de banda para óleo SAE40 a $20,1 \pm 0,2^{\circ} \mathrm{C}$, Resultado de quatro repetições a $1 \mathrm{MHz}$ usando a célula com conversão de modo $(\mathrm{CCM})$. . . . . . . . . . . . . . . . . . .

4.9 Magnitude do coeficiente de reflexão (a) e viscosidade (b) em função da largura de banda para glicerina U.S.P a $20,0 \pm 0,2^{\circ}$ C. Resultado de quatro repetições a $1 \mathrm{MHz}$ usando a célula com conversão de modo $(\mathrm{CCM}) . \ldots \ldots$. . . . . . . . . . .

4.10 Magnitude do coeficiente de reflexão em função da largura de banda para (a) óleo automotivo SAE40 a $23,1 \pm 0,3^{\circ} \mathrm{C}$ e (b) óleo mineral a $23,3 \pm 0,3^{\circ} \mathrm{C}$. Resultado de quatro repetições a $1 \mathrm{MHz}$ usando a célula com transdutor de cisalhamento (CTC). . . . . . .

5.1 Magnitude e variação de fase do coeficiente de reflexão em função da frequência, para todos os óleo automotivos SAE40, SAE90, SAE140 e SAE250 na banda de frequência equivalente a $\beta=0,55$ (CTC).

5.2 Magnitude (a) e variação de fase (b) em função do produto $\rho \eta_{0}$ para os óleos automotivos SAE40, SAE90, SAE140 e SAE250 (CTC). 79

5.3 Viscosidade (a) e elasticidade (b) em função da viscosidade dinâmica do líquido para todos os óleos automotivos (CTC). . . . . 80

5.4 Valores esperados de $\rho \eta_{0}$ em função da magnitude medida para três frequências e curvas ajustadas $(\mathrm{CCM})$. . . . . . . . . . . . 81

5.5 Arranjo experimental usado para testar o efeito das emulsões águaóleo na magnitude do coeficiente de reflexão (CTC). 
5.6 Magnitude medida em função do tempo e aquisição nos casos de óleo SAE90 contaminado por água e água contaminada por SAE40 (CTC). . . . . . . . . . . . . . . . . . . 84

5.7 Magnitude do coeficiente de reflexão medida em função do tempo de aquisição no ensaio feito para detectar a contaminação da água por óleo (CTC). . . . . . . . . . . . . . . . . . . . . 85 


\section{Lista de Tabelas}

3.1 Propriedades físicas dos líquidos testados. . . . . . . . . . . . . . 61

3.2 Propriedades físicas das amostras da mistura glicose de milho-água a $19,5 \pm 0,2^{\circ} \mathrm{C} \ldots \ldots \ldots \ldots$. . . . . . . . . . . . . . . . 61

3.3 Propriedades físicas do sólido usado na interface de medição. . . . 62

4.1 Resultados obtidos nos testes de medição da mudança de fase usando a célula com transdutor de cisalhamento (CTC) a $1 \mathrm{MHz} . \quad$. 75 


\section{Lista de Abreviaturas}

CCM Célula de medição com conversão de modo.

CTC Célula de medição com transdutor de cisalhamento.

LAN Rede de área local Local Area Network

PMMA Poli(metil metacrilato), acrílico. 


\section{Lista de Símbolos}

\begin{tabular}{|c|c|c|}
\hline símbolo & descrição & página \\
\hline$\alpha$ & Coeficiente de atenuação & 35 \\
\hline$\beta$ & $\begin{array}{l}\text { Parâmetro que define a largura da banda usada } \\
\text { no cálculo da magnitude do coeficiente de } \\
\text { reflexão }\end{array}$ & 55 \\
\hline$\gamma$ & Deformação de cisalhamento & 29 \\
\hline$\dot{\gamma}$ & Taxa de cisalhamento & 30 \\
\hline$\delta$ & $\begin{array}{l}\text { Defasagem entre a tensão e o deslocamento em } \\
\text { regime harmônico }\end{array}$ & 33 \\
\hline$\epsilon$ & Parâmetro do modelo de potência & 80 \\
\hline$\xi$ & Fração de massa em misturas de líquidos & 60 \\
\hline$\eta_{0}$ & $\begin{array}{l}\text { Viscosidade dinâmica ou a baixa frequência } \\
\text { medida com o viscosímetro rotacional em } \\
\text { regime Newtoniano }\end{array}$ & 31 \\
\hline$\eta$ & Viscosidade aparente & 30 \\
\hline$\theta$ & $\begin{array}{l}\text { Mudança de fase do coeficiente de reflexão } \\
\text { complexo, } \theta=\arg \left(R^{*}\right)\end{array}$ & 37 \\
\hline$\lambda$ & Comprimento de onda & 35 \\
\hline$\rho$ & Densidade do meio & 34 \\
\hline$\tau_{m}$ & Tempo de relaxação de Maxwell & 28 \\
\hline$\tau_{d}$ & $\begin{array}{l}\text { Período de tempo característico do processo de } \\
\text { deformação }\end{array}$ & 28 \\
\hline$\sigma$ & Tensão mecânica de cisalhamento & 30 \\
\hline
\end{tabular}

continua... 


\begin{tabular}{|c|c|c|}
\hline símbolo & descrição & página \\
\hline$\omega$ & Frequência angular & 32 \\
\hline$a(t)$ & $\begin{array}{l}\text { Pulso de medição refletido pela interface sólido- } \\
\text { amostra }\end{array}$ & 51 \\
\hline$A(f)$ & $\begin{array}{l}\text { Transformada de Fourier do pulso } a(t), A(f)= \\
\mathcal{F}\{a(t)\}\end{array}$ & 55 \\
\hline$D_{e}$ & Número de Débora & 28 \\
\hline$e$ & $\begin{array}{l}\text { Desvio porcentual entre a viscosidade dinâmica } \\
\text { e a viscosidade medida a alta frequência por } \\
\text { ultrassom }\end{array}$ & 62 \\
\hline$f$ & Frequência & 32 \\
\hline$G^{*}$ & Módulo de cisalhamento complexo & 34 \\
\hline$G^{\prime}$ & Módulo de armazenamento, $G^{\prime}=\Re\left(G^{*}\right)$ & 33 \\
\hline$G^{\prime \prime}$ & Módulo de perda, $G^{\prime \prime}=\Im\left(G^{*}\right)$ & 33 \\
\hline$G_{\infty}$ & Constante elástica do modelo de Maxwell & 41 \\
\hline$j$ & Unidade imaginária, $j=\sqrt{-1}$ & 34 \\
\hline$k$ & Módulo de rigidez & 31 \\
\hline$n(t)$ & $\begin{array}{l}\text { Pulso de normalização refletido pela interface } \\
\text { sólido-sólido }\end{array}$ & 51 \\
\hline$N(f)$ & $\begin{array}{l}\text { Transformada de Fourier do pulso } n(t), N(f)= \\
\mathcal{F}\{n(t)\}\end{array}$ & 55 \\
\hline$r$ & $\begin{array}{l}\text { Magnitude do coeficiente de reflexão complexo, } \\
r=\left|R^{*}\right|\end{array}$ & 37 \\
\hline$R$ & Coeficiente de reflexão complexo & 36 \\
\hline$t$ & Tempo & 30 \\
\hline$u$ & Deslocamento da partícula & 34 \\
\hline$v$ & Velocidade da partícula & 30 \\
\hline$W$ & Resistência acústica, $W=\Re(Z)$ & 35 \\
\hline
\end{tabular}




\begin{tabular}{lll}
\hline símbolo & descrição & página \\
\hline$X$ & Reatância acústica, $X=\Im(Z)$ & 35 \\
$z$ & Direção de propagação das ondas & 34 \\
$Z$ & Impedância acústica & 35 \\
\hline
\end{tabular}




\section{Introdução}

\subsection{Introdução e motivação}

As necessidades da indústria moderna, cada vez mais automatizada, têm impulsionado a pesquisa de novos métodos de medição visando aumentar a eficiência dos processos e, por conseguinte, a redução do custo final do produto. O ultrassom tem muitas aplicações na área de processos industriais, dentre as quais a medição da proximidade ou presença de objetos, a detecção de falhas em peças mecânicas, a medição de fluxo em tubulações e a caracterização de líquidos e sólidos. Essas aplicações devem-se às características das ondas acústicas que permitem obter informação do meio onde se propagam de uma maneira não invasiva.

As ondas acústicas em geral são perturbações de tensão mecânica que podem se propagar em quase qualquer meio sólido, líquido ou gasoso. Os parâmetros acústicos medidos como velocidade de propagação, atenuação e impedância acústica podem ser relacionados com algumas propriedades físicas do meio, tais como densidade, elasticidade, viscosidade, entre outras. Uma aplicação interessante do ultrassom é a caracterização de líquidos, que tem sido um tema de pesquisa bastante retratado nas últimas duas décadas. Pesquisas visando a monitoração ultrassônica da densidade, viscosidade, grau de homogeneização de misturas e emulsões, e o número de partículas em suspensões são comuns na literatura.

De todas as propriedades físicas do líquido, a viscosidade é a que requer maior consideração no estudo dos escoamentos, pois ela oferece resistência ao cisalhamento, dificultando o fluxo dos fluidos em tubulações, cavidades de moldes, etc. Além disso, é utilizada no controle da qualidade de produtos finais, sendo crucial sua medição nas industrias químicas, petroquímicas, farmacêuticas e de alimentos. A medição de viscosidade em baixas frequências, como a realizada 
pelo viscosímetro rotacional, não permite o controle de processos em tempo real, pois geralmente depende do arrasto de superfícies oscilatórias imersas no líquido.

Devido à altíssima atenuação apresentada pelas ondas de cisalhamento nos líquidos, torna-se praticamente impossível medir diretamente propriedades acústicas como a velocidade de propagação e o coeficiente de atenuação (HARRISON; BARLOW, 1981). No entanto, é possível determinar a impedância acústica de cisalhamento do líquido mediante a medição do coeficiente de reflexão complexo da onda de cisalhamento na interface definida entre um sólido de referência e o líquido em teste (MASON et al., 1949; COHEN-TENOUDJI et al., 1987; BUIOCHI, 2000).

O método da reflexão de ondas de cisalhamento apresenta-se como um método viável na busca de um viscosímetro que permita o controle de processos em tempo real. A determinação do coeficiente de reflexão complexo é feita comparando as amplitudes e fases dos sinais refletidos antes e depois do líquido ser colocado na interface de medição. Assim, medindo o coeficiente de reflexão complexo, obtémse o valor da impedância acústica complexa e, resolvendo a equação de onda para materiais elásticos com perdas viscosas, determina-se o módulo de cisalhamento complexo do líquido. A elasticidade é a parte real do módulo de cisalhamento complexo e a viscosidade é calculada a partir da razão entre a parte imaginária do módulo de cisalhamento complexo e a frequência angular da onda (HARRISON; BARLOW, 1981). O método apresenta as seguintes vantagens: é uma técnica não invasiva, permitindo seu uso em tanques, moldes e tubulações; a medição pode ser feita em líquido estático ou em movimento. Além disso, a onda penetra distâncias muito pequenas no líquido, da ordem de micrômetros, o que permite a monitoração de processos de filmes poliméricos ou polpa de papel.

A medição da viscosidade de líquidos por ultrassom tem sido uma linha de pesquisa na área de caracterização de líquidos no Laboratório de ultrassom do Departamento de Engenharia Mecatrônica e de Sistemas Mecânicos (PMR) da Escola Politécnica da Universidade de São Paulo (EPUSP) nos últimos anos. Como resultado, há publicações de vários artigos em revistas e congressos, uma tese de doutorado e uma dissertação de mestrado. Este trabalho pretende dar continuidade ao tema visando adquirir um melhor entendimento dos fenômenos envolvidos no método de medição. 


\subsection{Métodos de medição}

Para determinar as propriedades viscoelásticas de líquidos por ultrassom existem vários métodos, sendo que dois enfoques podem ser claramente diferenciados: método de ressonância e método de reflexão. O primeiro baseia-se na mudança da frequência de ressonância de um dispositivo piezelétrico ou magnetostritivo na presença de um líquido. O líquido pode estar em contato direto com o elemento ativo ou em contato com uma linha de retardo ou guia de onda. No segundo caso, uma onda é gerada pelo transdutor e propaga-se num outro meio sólido, uma linha de retardo ou uma guia de onda, que encontra-se em contato com o líquido. Comparam-se as ondas que retornam ao receptor nos casos com a amostra líquida e com um fluido de calibração, geralmente ar.

No método da frequência de ressonância, dispositivos que vibram de diferentes maneiras são usados. Os mais comuns são os dispositivos baseados em ressonadores de quartzo (AT-cut) que apresentam deformação de cisalhamento quando excitados no modo de espessura (BEHRENDS; KAATZE, 2001)(BADMAEV et al., 2006). Dispositivos de torção, que são geralmente de forma cilíndrica, são inseridos no líquido (KIEŁlCZYŃSKI; PAJEWSKI; SZLAWESKI, 2003)(VALTORTA; MAZZA, 2006). Além disso, existem dispositivos compostos por cerâmicas piezelétricas empilhadas e pré-tensionadas (transdutores de tipo sanduíche) associados a linhas de retardo escalonadas (amplificadores mecânicos). Na linha de retardo propagam-se ondas longitudinais e quando o extremo da linha de retardo é inserida no líquido a frequência de ressonância do sistema muda (PRUGNE et al., 1998).

O método da reflexão divide-se de acordo com o tipo de onda usado: ondas de cisalhamento, torcionais e de superfície. No caso das ondas de cisalhamento, trata-se de ondas de corpo (bulk waves) que podem incidir na interface sólidolíquido de maneira normal ou oblíqua (MASON et al., 1949). No caso das ondas torcionais, são usadas guias de onda, geralmente cilíndricas, e transdutores de cisalhamento ou magnetostritivos (SHEPARD et al., 1999)(VOGT; LOWE; CAWLEY, 2003)(SIMONETTI; CAWLEY, 2004). No caso das ondas de superfície usamse ondas de Love e de Bleustein-Gulyaev geralmente com dispositivos do tipo SAW (Surface Acoustic Waves) (KIEŁlCZYŃSKI; PLOWIEC, 1989)(ZHANG; CARON; VETELINO, 2001)(HU et al., 2008).

Os métodos de medição são resumidos a seguir: 
- Métodos de ressonância

- Dispositivos de cisalhamento

- Dispositivos de torção

○ Dispositivos com amplificadores mecânicos

- Métodos de reflexão

- Ondas de cisalhamento

- Incidência normal

- Incidência oblíqua

- Ondas torcionais

- Ondas de superfície

O presente trabalho trata do método da reflexão com ondas de cisalhamento e incidência normal, como mostrado no quadro acima.

\subsection{Estado da arte e trabalhos relacionados}

No século XIX já se sabia que algumas substâncias apresentam um comportamento intermediário entre um fluido ideal e um sólido perfeitamente elástico. James Clerk Maxwell, no ano de 1868, foi quem inicialmente concluiu que esse comportamento pode ser explicado supondo que a tensão é composta de duas partes: uma relacionada com a deformação elástica e modelada pela lei de Hooke e outra relacionada com a deformação viscosa e modelada pela lei da viscosidade de Newton (CHANDRASEKHAR, 1964). A teoria de Maxwell introduziu o conceito de tempo de relaxação $\left(\tau_{m}\right)$ que, segundo a teoria da cinética molecular dos líquidos (FRENKEL, 1946), define-se como a vida média de uma partícula na sua posição de equilíbrio. De acordo com esta teoria, supondo que o liquido é submetido a forças externas que variam periodicamente com a frequência angular $\omega$, se o produto $\omega \tau_{m} \gg 1$ o líquido comporta-se como um sólido elástico e se $\omega \tau_{m} \ll 1$ o comportamento é perfeitamente viscoso. Para valores perto de 1 tem-se comportamento simultaneamente elástico e viscoso, ou viscoelástico.

A teoria de Maxwell permite concluir que o comportamento apresentado por uma substância depende da taxa de cisalhamento, ou frequência, com a qual está sendo deformada. Usando baixa taxa de cisalhamento, como é o caso 
dos viscosímetros rotacionais, o efeito viscoelástico é visível somente nos fluidos mais viscosos, sendo que os líquidos menos viscosos podem ser considerados perfeitamente viscosos (newtonianos). No entanto, se a taxa de cisalhamento aumenta drasticamente, esses fluidos newtonianos vão começar a se comportar como viscoelásticos. Esse fenômeno foi verificado experimentalmente no ano de 1947 usando cristais de quartzo vibrando em modo torcional (MASON, 1947).

A natureza viscoelástica do líquido permite a propagação de ondas de cisalhamento, sugerindo a viabilidade de se medir propriedades do líquido, como a velocidade de propagação e a atenuação, relacionadas com a elasticidade e a viscosidade de cisalhamento. Contudo, a alta atenuação das ondas de cisalhamento em líquidos ocasiona a redução da amplitude a níveis desprezíveis em poucos micrômetros percorridos. Segundo Barlow e Subramaniam (BARLOW; SUBRAMANIAM, 1966) um líquido com viscosidade de 0,1 Pas à frequência de $10 \mathrm{MHz}$ tem uma atenuação de aproximadamente $10^{6}$ Nepers $/ \mathrm{m}$. Isso impossibilita o uso da técnica do pulso-eco (YONEDA; ICHIHARA, 2005).

Na segunda metade dos anos 40, o comportamento viscoelástico de líquidos a alta frequência era uma área de pesquisa muito ativa. Como era o início da era dos polímeros, os principais líquidos analisados eram polímeros líquidos, soluções poliméricas e óleos lubrificantes. Os dispositivos torcionais usados até então tinham um limite de trabalho de algumas centenas de $\mathrm{kHz}$ devido às pequenas dimensões requeridas. Acima disso era necessário um método diferente. Mason et al. (MASON et al., 1949) propuseram o método da reflexão das ondas de cisalhamento visando atingir a faixa dos $\mathrm{MHz}$. Nesse trabalho foram apresentadas as equações fundamentais para incidência normal e oblíqua, baseadas em modelos mecânicos com dois tempos de relaxação.

Nos anos posteriores vários autores pesquisaram sobre a aplicação e aperfeiçoamento do método (BARLOW; SUBRAMANIAM, 1966) (SHAH; BALASUBRAMANIAM, 1996) (HARRISON; BARLOW, 1981) (COHEN-TENOUDJI et al., 1987) (SHAH; BALASUBRAMANIAM, 2000) (BUIOCHI, 2000) (BALASUBRAMANIAM; SANKARAN; RAJWADE, 2004)(DIXON; LANYON, 2005) e sobre seu uso para determinar as propriedades viscoelásticas de líquidos como óleos lubrificantes (BARLOW, 1959) (BARLOW; LAMB, 1959) (BUIOCHI.; ADAMOWSKI; FURUKAWA, 1998) (BUIOCHI et al., 2003) (BUIOCHI et al., 2006), cristais líquidos (KIRK; MARTINOTY, 1976) (MARTINOTY et al., 1977) (MUKAI et al., 1997), fluidos usados como padrão de viscosidade (SHAH; BALASUBRAMANIAM, 2000), fluidos 
acoplantes para transmissão de ondas de cisalhamento (YONEDA; ICHIHARA, 2005), líquidos de baixa viscosidade como água (MCSKIMIN; ANDREATCH, 1967), entre outros.

No caso específico dos polímeros líquidos têm-se trabalhos onde o método foi usado com polidimetilsiloxano (BARLOW; HARRISON; LAMB, 1964), soluções de poliestireno (MOORE et al., 1967), polímeros flexíveis num meio nemático (MARTINOTY, 1983), asfalto (SHEEN; CHIEN; RAPTIS, 1995), resina epóxica (SHEEN; CHIEN; RAPTIS, 1995)(DIXON; LANYON, 2005), diisobutilftalato (DIBP) (BARLOW; SUBRAMANIAM, 1966), copolímeros do tipo acrílico (ALIG; TADJBAKHSCH; ZOSEL, 1998), polidometilsiloxano(PDMS) (LONGIN; VERDIER; PIAU, 1998) e óleos de solicone (GREENWOOD; BAMBERGER, 2002). Também foi usado na monitoração da cura de polímeros (COHEN-TENOUDJI et al., 1987) (DIXON; LANYON, 2005), formação de filmes poliméricos (polipropilenoglicol, policloropreno e polimetilmetacrilato) (ALIG et al., 1997) e estudo da transição ordem-desordem em copolímeros (ALIG et al., 2000).

Um campo de aplicação importante do método é a indústria de alimentos onde têm-se trabalhos relacionados com a medição das propriedades reológicas de misturas de goma xantana com sacarose (SAGGIN; COUPLAND, 2004a), gordura e óleos vegetais (SAGGIN; COUPLAND, 2004b) (SAGGIN; COUPLAND, 2001), gel de leite (BUCKIN; KUDRYASHOV, 2001) e misturas de mel com água (KULMYRZAEV; MCCLEMENTS, 2000) (GREENWOOD; BAMBERGER, 2002).

Outro uso interessante do método e que tem sido um tema de pesquisa ativo nos últimos anos é a monitoração do processo de cura do cimento Portland (SUN; VOIGT; SHAH, 2006) e do concreto (AKKAYA et al., 2003).

No trabalho de mestrado do candidato (FRANCO, 2006) foi feita uma ampla revisão bibliográfica do tema até o ano de 2005. A maioria dos trabalhos citados nos parágrafos anteriores foram discutidos salientando seus principais aportes e enfatizando os dispositivos de medição usados.

O autor reportou resultados experimentais importantes nos seus trabalhos publicados (FRANCO, 2006) (FRANCO; BUIOCHI, 2006) (FRANCO et al., 2006) (FRANCO et al., 2007) (FRANCO et al., 2008b) (FRANCO et al., 2008a) (FRANCO; ADAMOWSKI; BUIOCHI, 2010). Nesses trabalhos foi aprimorado o método experimental, melhorando a precisão na medição do coeficiente de reflexão (magnitude e fase). Foi usada uma célula que aproveita a conversão de 
modo para gerar as ondas de cisalhamento, ideia inicialmente proposta por Buiochi (BUIOCHI, 2000). Foram testados óleos automotivos com viscosidades progressivas, onde um crescente efeito viscoelástico foi observado. Além disso, foi mostrado que o método simplificado que usa somente a magnitude do coeficiente de reflexão para calcular a viscosidade somente fornece os valores esperados de viscosidade sob certas condições experimentais. Finalmente, valores de viscosidade por ultrassom, que estão em concordância com aqueles fornecidos pelo viscosímetro rotacional, foram obtidos com óleos comestíveis de baixa viscosidade. Esses resultados são importantes e de interesse para a comunidade científica.

Embora muitos trabalhos tenham sido escritos e o conhecimento do tema venha sendo ampliado, ainda não existem aplicações fora do ambiente de laboratório. Isso deve-se, principalmente, ao bom controle de temperatura necessário no teste, requisito de implementação não trivial numa aplicação prática na indústria. Outro problema consiste na necessidade de uma medição de calibração previa à medição com o líquido. Isso faz o método demorado devido ao processo de limpeza do dispositivo entre medições.

Até o momento, os resultados experimentais obtidos por outros pesquisadores não apresentaram uma boa concordância com a teoria para líquidos newtonianos. Vários autores explicaram essas diferenças devido aos efeitos de relaxação. No entanto, segundo a teoria, esses efeitos de relaxação somente devem ocorrer no caso dos líquidos mais viscosos e com moléculas complexas.

\subsection{Objetivos}

\subsubsection{Objetivo geral}

O objetivo geral do trabalho é, usando o método da reflexão de ondas de cisalhamento na interface sólido-líquido, ampliar o entendimento dos fenômenos físicos envolvidos na medição das propriedades viscoelásticas de líquidos por ultrassom e analisar possíveis aplicações do método na indústria.

\subsubsection{Objetivos específicos}

O objetivo geral pode-se subdividir nos seguintes objetivos específicos:

- Projetar e fabricar uma célula com conversão de modo e usá-la para obter 
resultados experimentais que permitam analisar o método de medição.

- Estudar a discrepância observada, no caso de líquidos newtonianos, entre os resultados experimentais obtidos por ultrassom e os esperados pela teoria.

- Implementar novos métodos experimentais que permitam obter a viscosidade dinâmica a partir dos resultados obtidos por ultrassom.

- Projetar e fabricar uma célula de medição utilizando transdutores de cisalhamento e usá-la para obter resultados experimentais.

- Realizar medições com diferentes líquidos abrangendo uma faixa de viscosidade ampla, principalmente aqueles que permitem realizar misturas para obter amostras de viscosidade variável, como glicose de milho e glicerina.

- Estudar técnicas de análise dos sinais que permitam melhorar a determinação das quantidades mensuráveis. 


\section{Bases teóricas do método de medição}

\subsection{Sólidos e líquidos na reologia}

A ideia geral que se tem sobre sólidos e líquidos baseia-se principalmente na resposta que apresentam a tensões relativamente baixas e em uma escala de tempo muito reduzida. Essa escala humana de tempo varia entre uns poucos segundos e alguns minutos, tempo suficiente para que, por exemplo, a maioria dos líquidos fluam e os sólidos conservem sua forma parecendo imutáveis. Porém, um líquido deformado num espaço de tempo muito curto apresenta comportamento elástico, próprio dos sólidos, e um sólido submetido a uma tensão contínua pode fluir, apresentando comportamento próprio de líquidos, se a escala de tempo for muito grande. Então, um material pode ser considerado como sólido ou líquido dependendo da escala de tempo do processo de deformação (BARNES; HUTTON; WALTERS, 1989). Em reologia é usado um parâmetro adimensional chamado de número de Débora $\left(D_{e}\right)$ para quantificar essa escala de tempo:

$$
D_{e}=\frac{\tau_{m}}{\tau_{d}}
$$

onde $\tau_{d}$ o tempo característico do processo de deformação e $\tau_{m}$ é o tempo característico do material ou tempo de relaxação. O parâmetro $D_{e}$ é infinito para um sólido de Hooke e zero para um líquido newtoniano.

A reologia é a ciência que estuda a deformação e o fluxo da matéria. Abrange os materiais que apresentam comportamento intermediário entre um líquido perfeitamente viscoso, chamado de líquido newtoniano, e um sólido perfeitamente elástico, chamado de sólido de Hooke, mas excluindo esses dois casos extremos. O comportamento de líquidos newtonianos e sólidos de Hooke são estudados pela mecânica dos fluidos e pela mecânica de sólidos, respectivamente. A reologia foi criada para descrever o comportamento de materiais como os polímeros, resinas 
poliméricas, detergentes líquidos, tintas, colas, entre muitos outros.

O conceito de sólidos e líquidos fornecido pela reologia é fundamental neste trabalho para explicar o principio de medição usado. A maioria dos líquidos testados são newtonianos, porém, a frequências ultrassônicas, apresentam um certo nível de elasticidade que permite a propagação de ondas de cisalhamento numa interface sólido-líquido. A transmissão da onda de cisalhamento para o líquido é pequena e a distância percorrida é da ordem de micrômetros. Dessa maneira, pode-se medir a onda refletida, de forma a se estimar a onda transmitida, e por sua vez será relacionada com as propriedades viscoelásticas do líquido.

\subsection{Tensão e deformação de cisalhamento}

\subsubsection{Deformação e taxa de deformação}

A deformação de cisalhamento simples consiste no movimento de sucessivas camadas de material com respeito a uma camada de referência, de tal maneira que o deslocamento de uma camada é proporcional à sua distância da camada de referência. Pode-se fazer uma analogia com um baralho colocado sobre uma mesa onde a carta superior é deslizada. A figura 2.1 mostra uma camada de material submetida a tensão de cisalhamento $\sigma$ e nas suas posições de repouso e deformada. A separação relativa entre duas camadas dividida pela altura total $\delta l / h$ é chamada de deformação de cisalhamento simples. Nesse caso, não há mudança na direção perpendicular ao plano de movimento.

A partir da figura 2.1, pode-se ver que as linhas originalmente perpendiculares ao plano de referência giram um ângulo $\gamma$, onde:

$$
\tan \gamma=\frac{\delta l}{h}
$$

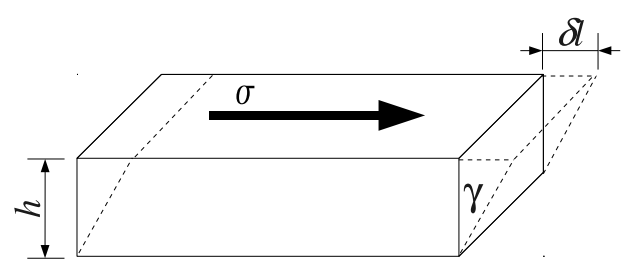

Figura 2.1: Deformação de um elemento retangular submetido a tensão de cisalhamento simples. 
Se a deformação é pequena o suficiente, o ângulo de cisalhamento é igual à deformação de cisalhamento:

$$
\gamma \approx \frac{\delta l}{h}
$$

onde $\gamma$ é a deformação de cisalhamento.

A mudança instantânea da deformação de cisalhamento $\dot{\gamma}$, ou taxa de cisalhamento, é dada por:

$$
\dot{\gamma}=\frac{\partial \gamma}{\partial t}
$$

Sendo o fluxo linear, uma camada separada uma distância $h$ da camada de referência, movimentando-se com velocidade $v$, vai percorrer uma distância $\delta l=v \delta t$ num tempo $\delta t$, então:

$$
\dot{\gamma}=\frac{\partial}{\partial t}\left\{\frac{\delta l}{h}\right\}=\frac{v}{h} .
$$

É importante esclarecer que o gradiente de velocidade $v / h$ é igual à taxa de cisalhamento somente quando as linhas de fluxo são retas (WHORLOW, 1992), hipótese considerada neste trabalho.

\subsubsection{Relação tensão-deformação}

No elemento de material tensionado, conforme mostrado na seção anterior (figura 2.1), dois tipos extremos de comportamento podem acontecer, como dito na seção 2.1. No primeiro, se o material é um líquido newtoniano, apresenta-se um fluxo ou deslizamento que vai perdurar enquanto a tensão seja mantida. Esses líquidos são chamados de newtonianos devido a que foi Sir Isaac Newton quem na sua famosa publicação do ano 1687, os "Principia", descreveu esse comportamento pela primeira vez. Basicamente, a teoria diz que a resistência ao movimento é proporcional à taxa de deformação, assim:

$$
\sigma=\eta \dot{\gamma}
$$

onde $\sigma$ é a tensão de cisalhamento e $\eta$ é a viscosidade (constante de proporcionalidade). A viscosidade é uma propriedade importante dos líquidos e pode-se definir como atrito interno ou resistência ao fluxo. Mesmo que essas ideias tenham sido introduzidas por Newton em 1687, foi até o século XIX que os cientistas Navier e Stokes desenvolveram uma teoria tridimensional consistente. Assim, as equações que governam o comportamento de um líquido newtoniano 
viscoso são chamadas de equações de Navier-Stokes (BARNES; HUTTON; WALTERS, 1989). A viscosidade define-se como:

$$
\eta=\frac{\text { Tensão de cisalhamento }}{\text { Taxa de cisalhamento }} .
$$

$\eta$ é constante para líquidos newtonianos, sendo chamada de viscosidade dinâmica e representada por $\eta_{0}$.

No outro comportamento extremo, o material deforma-se instantaneamente e permanece deformado, sem nenhum outro movimento, pelo tempo que a tensão é mantida. Depois de liberada a tensão, o elemento de material retorna ao estado inicial. Esse comportamento é chamado de sólido perfeitamente elástico e é modelado pela lei de Hooke:

$$
\sigma=k \gamma
$$

onde $k$ é chamado de módulo de rigidez e é definido como:

$$
k=\frac{\text { Tensão de cisalhamento }}{\text { Deformação }} .
$$

Segundo a teoria de Maxwell, a tensão de cisalhamento $\sigma$ resultante num meio viscoelástico é ocasionada por uma componente elástica, proporcional à deformação, e uma componente viscosa, proporcional à velocidade de deformação. No caso unidimensional, supondo materiais com comportamento linear, pode-se escrever (WHORLOW, 1992):

$$
\sigma=\eta \frac{\partial \gamma}{\partial t}+k \gamma
$$

Em geral, a viscosidade $\eta$ e a elasticidade $k$ são diferentes daquelas das equações 2.6 e 2.8. Isso acontece porque, neste caso, o material é viscoelástico e tanto $\eta$ como $k$ podem depender da taxa de cisalhamento.

A relação tensão-deformação apresentada acima é a mais simples possível, sendo equivalente ao modelo de Kelvin-Voigt para materiais viscoelásticos. Esse modelo está constituído por uma mola e um amortecedor viscoso dispostos em paralelo. Nesse caso, pode-se estabelecer a igualdade na deformação o que leva à equação 2.10. Existem outros tipos de relação tensão-deformação, por exemplo, o arranjo da mola e do amortecedor em série que leva ao conhecido modelo de Maxwell, podendo estabelecer a igualdade na tensão. Além disso, existem modelos mais complexos com arranjos diferentes para qualquer número de molas e amortecedores. Contudo, somente o caso do modelo de Kelvin-Voigt leva a uma equação de onda com solução analítica conhecida (ver seção 2.7). 


\subsubsection{Uso do termo "viscosidade"}

O termo viscosidade tem vários significados, dependendo do contexto onde está sendo usado. Neste trabalho, todas as tensões são de cisalhamento, por conseguinte, o termo viscosidade faz-se referência à viscosidade de cisalhamento. No caso da viscosidade de cisalhamento, existem dois casos a considerar. O primeiro é a viscosidade dinâmica, que independe da taxa de cisalhamento e é uma propriedade dos líquidos quando comportam-se em regime newtoniano. O segundo é a viscosidade dependente da taxa de cisalhamento num líquido não-newtoniano. A viscosidade medida por ultrassom, em geral dependente da taxa de cisalhamento, é chamada de viscosidade aparente sendo representada simplesmente por $\eta$. Os métodos experimentais usados para determinar $\eta_{0}$ e $\eta$ são apresentados no capítulo 3.

\subsection{Propagação de ondas de cisalhamento num meio viscoelástico}

Em ondas de cisalhamento, as partículas do meio se movimentam perpendicularmente à direção de propagação da onda. Esse movimento das partículas, ou oscilação, pode estar orientado em qualquer direção nesse plano perpendicular à direção de propagação, essa orientação é uma propriedade da onda chamada de polarização. Claramente podem existir infinitas ondas de cisalhamento dependendo da sua polarização, que podem ser representadas por apenas duas ondas, ou componentes, com diferença de polarização de $90^{\circ}$ entre elas. Nesse caso, a direção depende da amplitude relativa das duas componentes. Como, neste trabalho, as ondas de cisalhamento sempre incidem normalmente na interface, a polarização das ondas não precisa ser levada em conta. O tratamento unidimensional do problema é suficiente para todos os propósitos e a consideração dos meios de propagação como homogêneos e isotrópicos é uma excelente aproximação.

\subsubsection{Módulo de cisalhamento complexo}

Assumem-se que a tensão e, portanto, a deformação mudam ciclicamente com o tempo, com amplitudes $\sigma_{0}$ e $\gamma_{0}$, respectivamente, e frequência $f=\omega / 2 \pi$. Da equação 2.10, a tensão é a soma de duas componentes. O primeiro termo é a 


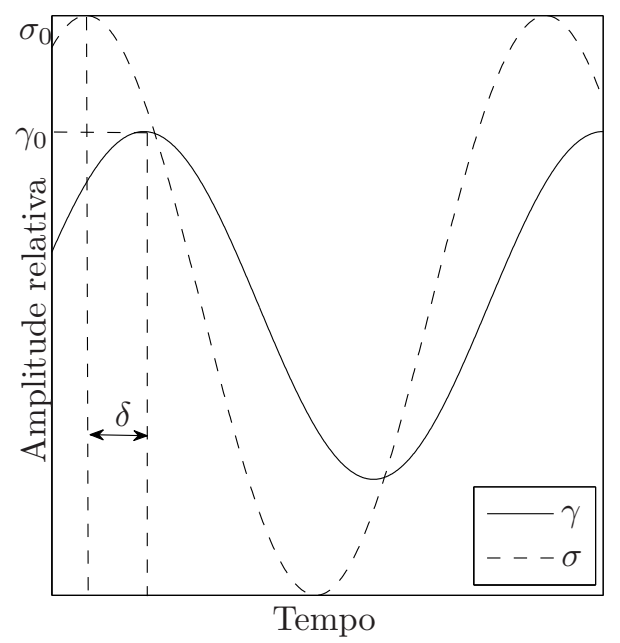

Figura 2.2: Formas de ondas da tensão $\sigma$ e da deformação $\gamma$ em regime harmônico.

componente viscosa, cuja deformação está atrasada $90^{\circ}$ em relação à tensão, e o segundo termo é a componente elástica, cuja deformação está em fase com a tensão. Se ambas as componentes são diferentes de zero, então a deformação e a tensão estão defasadas um valor $0<\delta<90^{\circ}$.

A figura 2.2 mostra as formas de onda da tensão e da deformação em regime harmônico com defasagem $\delta$. Supondo que a deformação apresenta sua máxima amplitude na origem, tem-se:

$$
\gamma=\gamma_{0} \cos \omega t
$$

e a tensão fica:

$$
\begin{aligned}
\sigma & =\sigma_{0} \cos (\omega t+\delta) \\
& =\sigma_{0} \cos \delta \cos \omega t-\sigma_{0} \sin \delta \sin \omega t \\
& =\gamma_{0}\left(G^{\prime} \cos \omega t-G^{\prime \prime} \sin \omega t\right) \\
& =G^{\prime} \gamma+\frac{G^{\prime \prime}}{\omega} \dot{\gamma}
\end{aligned}
$$

onde $G^{\prime}$ and $G^{\prime \prime}$ são chamados de módulo de armazenamento (ou elástico) e módulo de perda, respectivamente, e estão definidos como:

$$
G^{\prime}=\frac{\sigma_{0} \cos \delta}{\gamma_{0}}=\frac{\text { Amplitude da tensão em fase }}{\text { Amplitude da deformação }},
$$


e

$$
G^{\prime \prime}=\frac{\sigma_{0} \sin \delta}{\gamma_{0}}=\frac{\text { Amplitude da tensão em quadratura }}{\text { Amplitude da deformação }}
$$

Chamando o termo $\sigma_{0} e^{j \delta}$ como "amplitude complexa de $\sigma$ ", onde $j=\sqrt{-1}$ é a unidade imaginária, o módulo de cisalhamento complexo define-se como:

$$
G^{*}=\frac{\sigma_{0} e^{j \delta}}{\gamma_{0}}=\frac{\text { Amplitude da tensão complexa }}{\text { Amplitude da deformação complexa }}
$$

que em termos da suas componentes fica:

$$
G^{*}=G^{\prime}+j G^{\prime \prime}
$$

sendo:

$$
\tan \delta=\frac{G^{\prime \prime}}{G^{\prime}}
$$

Comparando a equação (2.12) com a equação (2.10), tem-se:

$$
\eta=\frac{G^{\prime \prime}}{\omega}
$$

onde $\eta$ corresponde à viscosidade obtida à frequência de trabalho $\omega / 2 \pi$.

\subsubsection{Equação de onda}

Aplicando a segunda lei de Newton ao volume de material mostrado na figura 2.1 e usando a relação tensão-deformação apresentada na equação (2.10), pode-se chegar à seguinte equação diferencial que representa uma onda propagando-se num meio elástico com perdas viscosas:

$$
\rho \frac{\partial^{2} u}{\partial t^{2}}=G^{\prime} \frac{\partial^{2} u}{\partial z^{2}}+\frac{G^{\prime \prime}}{\omega} \frac{\partial^{3} u}{\partial z^{2} \partial t}
$$

onde $u$ é o deslocamento da partícula, $\rho$ é a densidade do meio em repouso e $z$ é a direção de propagação da onda. Para regime harmônico, a equação de onda fica reduzida à equação de Helmholtz, assim:

$$
\frac{d^{2} u}{d z^{2}}+\left[\frac{\rho \omega^{2}}{G^{*}}\right] u=0
$$

Finalmente, como as ondas de cisalhamento propagam-se distâncias muito pequenas num meio líquido viscoelástico, a solução da equação (2.20) para um meio semi-infinito é a solução de interesse neste trabalho:

$$
u(z, t)=u_{0} e^{-\alpha z} e^{j(\omega t-2 \pi z / \lambda)},
$$


onde $u_{0}$ é a amplitude inicial da onda, $\alpha$ é o coeficiente de atenuação e $\lambda$ é o comprimento de onda. $\alpha(\mathrm{em} \mathrm{Np} / \mathrm{m})$ indica o decaimento da amplitude da onda onde $1 / \alpha$, chamada de profundidade de penetração, é a distância ao longo da qual a amplitude da onda decresce a um valor de $1 / e$ vezes a amplitude inicial.

\subsubsection{Impedância acústica}

A impedância acústica $Z$ é uma propriedade que todo meio apresenta e é definida como a razão entre a tensão aplicada e a velocidade induzida na partícula, assim:

$$
Z=\frac{\sigma}{v}
$$

Deve-se levar em conta que a impedância acústica varia de sinal dependendo se a onda propaga-se para frente ou para trás, contudo, na maioria dos casos somente é usado o seu valor absoluto e o sinal é definido pelo contexto onde está sendo usado. Considerando uma onda plana, a impedância acústica num meio perfeitamente elástico, ou seja, sem atenuação, está relacionada com as propriedades físicas do meio pela seguinte relação:

$$
Z=\rho c,
$$

onde $\rho$ e $c$ são a densidade e a velocidade de propagação do meio, respectivamente (ROSENBAUM, 1988). A densidade considerada neste trabalho é a do meio em repouso, que é uma boa aproximação devido aos meios serem praticamente incompressíveis às tensões usadas. No caso de ondas longitudinais ou transversais em sólidos isotrópicos, como os metais e muitos polímeros, e ondas longitudinais em líquidos, que apresentam atenuação relativamente baixa para as frequências usadas neste trabalho, a equação 2.23 é uma excelente representação da impedância acústica. No caso das ondas transversais em líquidos, a velocidade de propagação, e portanto a impedância acústica, tem uma componente imaginária da mesma ordem, ou inclusive maior, que a sua componente real. Nesse caso, deve-se usar a seguinte equação mais geral (WHORLOW, 1992):

$$
Z^{*}=\sqrt{\rho G^{*}}=\sqrt{\rho\left(G^{\prime}+j G^{\prime \prime}\right)}
$$

$Z^{*}$ representa ao mesmo tempo a velocidade de propagação e a atenuação da onda (KINO, 1987). As componentes real e imaginária da impedância acústica são chamadas de resistência acústica $(W)$ e de reatância acústica $(X)$, ou seja:

$$
Z^{*}=W+j X .
$$




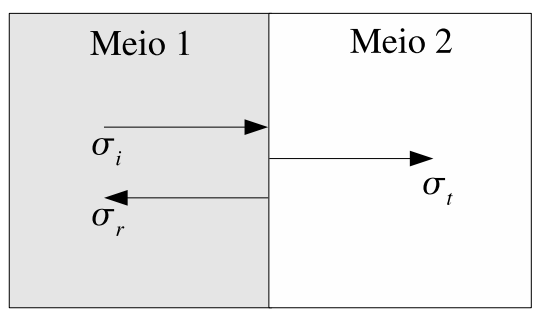

Figura 2.3: Reflexão de uma onda de cisalhamento na interface entre dois meios de diferente impedância acústica.

Das equações anteriores tem-se:

$$
G^{\prime}=\frac{W^{2}-X^{2}}{\rho} \quad \text { e } \quad G^{\prime \prime}=\frac{2 W X}{\rho},
$$

que ao serem resolvidas em $W$ e $X$, chega-se às seguintes equações para as componentes da impedância acústica em função das componentes do módulo de cisalhamento:

$$
W=\sqrt{\frac{\rho\left(\left|G^{*}\right|+G^{\prime}\right)}{2}} \quad \text { e } \quad X=\frac{\rho G^{\prime \prime}}{\sqrt{2 \rho\left(\left|G^{*}\right|+G^{\prime}\right)}},
$$

onde $\left|G^{*}\right|$ é a magnitude do módulo de cisalhamento complexo.

\subsection{Fenômeno de reflexão na interface sólido- líquido}

Quando uma onda incide normalmente numa interface plana entre dois meios com impedâncias acústicas diferentes, uma parte da onda é refletida e a outra é transmitida, conforme mostra a figura 2.3. Para essa condição, define-se o coeficiente de reflexão $R$ como a razão entre as tensões mecânicas refletida $\sigma_{r}$ e incidente $\sigma_{i}(\mathrm{KINO}, 1987)$ :

$$
R=\frac{\sigma_{r}}{\sigma_{i}}
$$

que pode ser expressada em termos das impedâncias acústicas características dos meios:

$$
R=\frac{Z_{2}-Z_{1}}{Z_{2}+Z_{1}}
$$

onde $Z_{1}$ e $Z_{2}$ são as impedâncias acústicas do meio 1 e do meio 2 , respectivamente. $Z$ e $R$ são, em geral, grandezas complexas devido à atenuação. Neste trabalho, dois casos são de interesse: a interface sólido-sólido e a interface sólido-líquido. No caso da interface sólido-sólido, as impedâncias dos dois meios podem ser 
consideradas reais e o coeficiente de reflexão é dado por:

$$
R=\frac{Z_{2}-Z_{1}}{Z_{2}+Z_{1}}=\frac{\rho_{2} c_{2}-\rho_{1} c_{1}}{\rho_{2} c_{2}+\rho_{1} c_{1}}
$$

Já no caso da interface sólido-líquido, a impedância acústica do líquido deve ser considerada complexa. A partir da equação (2.24), tem-se:

$$
R^{*}=\frac{Z_{2}^{*}-Z_{1}}{Z_{2}^{*}+Z_{1}}=\frac{\sqrt{\rho_{2} G_{2}^{*}}-\rho_{1} c_{1}}{\sqrt{\rho_{2} G_{2}^{*}}+\rho_{1} c_{1}} .
$$

Pode-se representar o coeficiente de reflexão por uma magnitude $r$ e uma mudança de fase $\theta$, relacionadas com a variação da amplitude e a defasagem da onda no processo de reflexão, respectivamente, com respeito a uma medição prévia de calibração. Assim, tem-se:

$$
R^{*}=r e^{j(\pi-\theta)}=-r e^{-j \theta} .
$$

Quando o segundo meio é o vácuo, ou na prática o ar, ocorre uma reflexão completa com inversão da fase $\left(180^{\circ}\right)$. A presença do líquido causa um decréscimo na magnitude e uma mudança de fase. Dessa maneira, a fase da onda no processo de reflexão é dada por $\pi-\theta \cdot r$ e $\theta$ são as quantidades mensuráveis do método e as técnicas experimentais usadas para sua medição são estudadas no capítulo 3. Pela natureza do fenômeno físico e a definição da equação (2.32) as quantidades mensuráveis têm, teoricamente, a seguinte variação:

$$
\begin{aligned}
& 0 \leq r \leq 1 \\
& 0 \leq \theta \leq 90^{\circ}
\end{aligned}
$$

Quando $r=0$, não há diferença de impedância entre os dois meios, ou seja, não há reflexão; quando $r=1$, uma grande diferença de impedância causa uma reflexão completa. No caso da fase, $\theta=0$ quando o segundo meio é um sólido perfeitamente elástico, $\theta>0$ para líquidos, aumentando com a viscosidade. Contudo, o valor final teórico de $\theta=90^{\circ}$ nunca foi observado experimentalmente. Além disso, o modelo para líquido newtoniano, mostrado na seção 2.6, prediz um valor máximo menor que $90^{\circ}$. 


\subsection{Propriedades viscoelásticas do líquido}

Manipulando as equações da seção anterior podem ser obtidas relações para a elasticidade e a viscosidade em função das quantidades mensuráveis $r$ e $\theta$ (DIXON; LANYON, 2005):

$$
G^{\prime}=\frac{Z_{S}^{2}}{\rho_{L}}\left[\frac{\left(1-r^{2}\right)^{2}-(2 r \sin \theta)^{2}}{\left(1+r^{2}+2 r \cos \theta\right)^{2}}\right],
$$

e

$$
\eta=\frac{G^{\prime \prime}}{\omega}=\frac{Z_{S}^{2}}{\rho_{L} \omega}\left[\frac{4 r\left(1-r^{2}\right) \sin \theta}{\left(1+r^{2}+2 r \cos \theta\right)^{2}}\right] .
$$

As propriedades viscoelásticas do líquido, a uma frequência $\omega$, podem ser determinadas pela medição da magnitude e da fase do coeficiente de reflexão complexo, se a impedância acústica do sólido $Z_{S}$ e a densidade do líquido $\rho_{L}$ são conhecidas.

\subsection{Relações válidas em regime newtoniano}

Supondo que o comportamento do líquido é predominantemente newtoniano, ou seja, o valor de $G^{\prime}$ é pequeno quando comparado ao valor de $G^{\prime \prime}$, assumir $G^{\prime}=0$ é uma boa aproximação. Igualando a zero a equação (2.33), chega-se a uma relação direta entre $r$ e $\theta$, assim (SHAH; BALASUBRAMANIAM, 2000):

$$
1-2 r^{2}\left(1+2 \sin ^{2} \theta\right)+r^{4}=0 .
$$

A relação anterior não depende das propriedades físicas do sólido nem do líquido. Pode-se reduzir a equação (2.35) para se obter o valor da fase a partir da amplitude, assim:

$$
\theta=\frac{1}{2} \cos ^{-1}\left[1-\frac{\left(1-r^{2}\right)^{2}}{2 r^{2}}\right] .
$$

De maneira similar, pode-se obter o valor da amplitude a partir da fase, solucionando o polinômio de quarta ordem em $r$. Isso é feito reduzindo a equação (2.35) a um polinômio biquadrático com a troca de variável $z=r^{2}$, ficando:

$$
z^{2}-A z+1=0
$$


onde $A=2\left(1+2 \sin ^{2} \theta\right)$. Após a solução da equação (2.37), substitui-se a variável inicial resultando na seguinte equação:

$$
r= \pm\left[1+2 \sin ^{2} \theta \pm \sqrt{\left(1+\sin ^{2} \theta\right)^{2}-1}\right]
$$

A equação anterior possui quatro soluções, mas lembrando que $r$ somente pode ter valores entre 0 e 1, três soluções são eliminadas. A solução de interesse é aquela com os sinais + e - , receptivamente. $r$ e $\theta$ dependem da frequência e, para um líquido de determinada viscosidade, os seus valores são únicos a determinada frequência.

A equação (2.36) permite obter a fase a partir somente da magnitude medida. No caso contrário, a equação (2.38) permite obter a magnitude a partir da fase medida. Em ambos os casos, pode-se calcular a viscosidade mediante a equação (2.34). Esses resultados têm uma grande influência sobre o método experimental porque permitem simplificar consideravelmente o processo de medição. Substituindo a equação (2.36) na equação (2.34), chega-se à seguinte relação para a viscosidade dependente somente de $r$ :

$$
\eta=\frac{2 Z_{S}^{2}}{\rho_{L} \omega}\left[\frac{1-r^{2}}{1+r^{2}+\sqrt{r^{2}\left(6-r^{2}\right)-1}}\right]^{2} .
$$

Alguns autores usam a seguinte equação mais simplificada (COHEN-TENOUDJI et al., 1987):

$$
\eta=\frac{2 Z_{S}^{2}}{\rho_{L} \omega}\left[\frac{1-r}{1+r}\right]^{2},
$$

obtida a partir da equação (2.34), onde o seno do numerador é obtido resolvendose a equação (2.35) para $\sin \theta$ e o cosseno do denominador é eliminado supondo-se que $\cos \theta \approx 1$ para valores de $\theta$ pequenos. As equações (2.39) e (2.40) apresentam resultados muito similares para valores de $r$ perto da unidade. No entanto, para valores de $r$ menores que 0,8 , a diferença se torna-se apreciável e a equação (2.39) deve ser usada (FRANCO et al., 2008b).

A impedância acústica do líquido em regime newtoniano é dependente somente do módulo de perda. A partir da equação (2.24), tem-se:

$$
Z_{L}^{*}=\sqrt{j \rho G^{\prime \prime}}=\sqrt{\frac{\rho G^{\prime \prime}}{2}}+j \sqrt{\frac{\rho G^{\prime \prime}}{2}} .
$$

Os valores de $W$ e $X$ são iguais em regime newtoniano. Em função da viscosidade, 
a impedância acústica do líquido fica (KASOLANG; DWYER-JOYCE, 2008):

$$
Z_{L}^{*}=\sqrt{j \omega \rho \eta}
$$

Isolando os termos que dependem de $r$ na equação (2.39), e calculando a raiz quadrada de ambos os lados, pode-se escrever, conforme deduzido neste trabalho:

$$
\frac{\sqrt{\omega \rho_{L} \eta}}{Z_{S}}=\frac{\left|Z_{L}^{*}\right|}{Z_{S}}=\sqrt{2}\left[\frac{1-r^{2}}{1+r^{2}+\sqrt{r^{2}\left(6-r^{2}\right)-1}}\right],
$$

onde $\left|Z_{L}^{*}\right|$ é a magnitude da impedância acústica do líquido em regime newtoniano. O mesmo pode ser feito com a equação (2.40).

\subsection{Modelos simples para materiais viscoelásticos}

No caso de líquidos mais viscosos e com estrutura molecular mais complexa, como resinas poliméricas, óleos automotivos ou muitos produtos alimentícios, o efeito elástico no líquido é considerável nas frequências de trabalho usadas. Nesses casos, o modelo newtoniano não é satisfatório e outros modelos que representem o comportamento das propriedades viscoelásticas do líquido em função da frequência são necessários.

Nesta seção, os modelos mais simples para materiais viscoelásticos são apresentados: modelo de Kelvin-Voigt e modelo de Maxwell representados na figura 2.4. O primeiro é usado no método de medição e o segundo permite a análise qualitativa do fenômeno viscoelástico com a frequência, incluindo a análise das quantidades mensuráveis. A modelagem quantitativa dos valores viscoelásticos medidos por ultrassom requer modelos diferentes, com maior número de parâmetros.

\subsubsection{Modelo de Kelvin-Voigt}

O método de medição usado neste trabalho baseia-se na mesma relação tensãodeformação do modelo de Kelvin-Voigt, o qual é representado por meio de uma mola perfeitamente elástica arranjada em paralelo com um amortecedor perfeitamente viscoso, como mostrado na figura 2.4a. Neste caso, a deformação de cisalhamento é igual nos dois elementos, levando à relação tensão-deformação mostrada na equação (2.10). Esse modelo é muito importante porque é um dos 
(a)

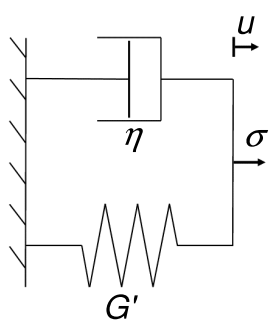

(b)

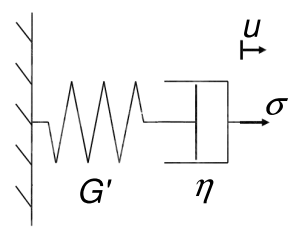

Figura 2.4: Modelos de Kelvin-Voigt (a) e Maxwell (b) para materiais viscoelásticos.

mais simples e o único que leva a uma solução analítica da equação de onda (seção 2.3.2). Nesse modelo, a viscosidade não depende da frequência.

\subsubsection{Modelo de Maxwell}

O modelo de Maxwell é representado por meio de uma mola perfeitamente elástica arranjada em série com um amortecedor perfeitamente viscoso, como mostrado na figura 2.4b. Nesse caso a tensão de cisalhamento é igual nos dois elementos, levando à seguinte relação tensão-deformação:

$$
\frac{\partial \gamma}{\partial t}=\frac{1}{G_{\infty}} \frac{\partial \sigma}{\partial t}+\frac{\sigma}{\eta}
$$

onde o parâmetro $G_{\infty}$ é definido como:

$$
G_{\infty}=\lim _{\omega \rightarrow \infty} G^{\prime}
$$

Assumindo que a tensão e a taxa de cisalhamento variam harmonicamente, as componentes do módulo de cisalhamento complexo são (BARLOW; SUBRAMANIAM, 1966):

$$
G^{\prime}(\omega)=\frac{G_{\infty} \omega^{2} \tau_{m}^{2}}{1+\omega^{2} \tau_{m}^{2}} \quad \text { e } \quad G^{\prime \prime}(\omega)=\frac{G_{\infty} \omega \tau_{m}}{1+\omega^{2} \tau_{m}^{2}}
$$

onde $\tau_{m}$ é o tempo de relaxação de Maxwell, dado por:

$$
\tau_{m}=\frac{\eta_{0}}{G_{\infty}}
$$

onde $\eta_{0}$ é a viscosidade dinâmica do líquido. Reiterando que no modelo de Maxwell a viscosidade é dependente da frequência, substituindo as equações (2.18) 


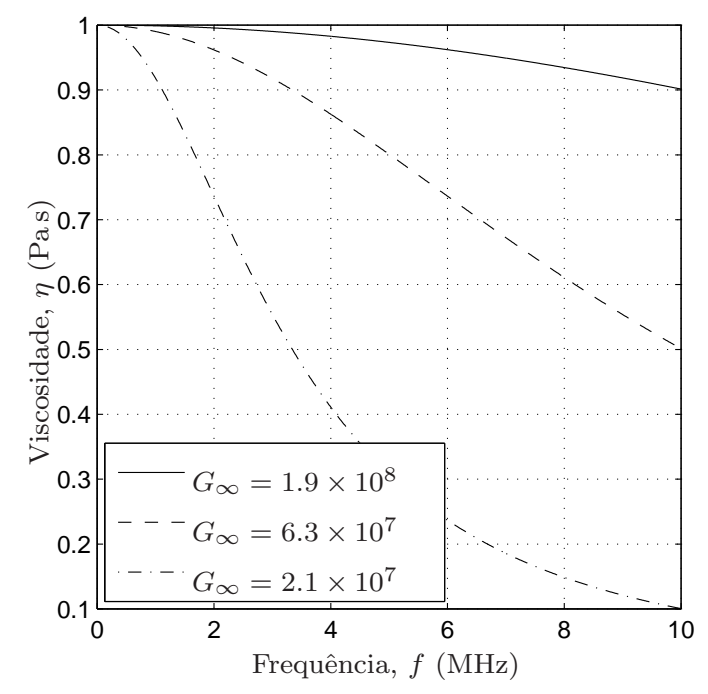

Figura 2.5: Viscosidade em função da frequência obtida com o modelo de Maxwell para três valores de $G_{\infty}(\mathrm{Pa})$.

e (2.46) na equação (2.47), tem-se (BARLOW; LAMB, 1959):

$$
\eta=\frac{\eta_{0}}{1+\omega^{2} \tau_{m}^{2}}
$$

O modelo de Maxwell fornece uma descrição qualitativa do comportamento da elasticidade e da viscosidade em função da frequência em materiais viscoelásticos. Embora o modelo não permita um ajuste quantitativo dos dados experimentais, ele pode ser usado para entender o comportamento das quantidades mensuráveis quando o efeito viscoelástico aumenta, como mostrado na seção 2.8 mais à frente.

Para mostrar o comportamento de um material viscoelástico com a frequência segundo o modelo de Maxwell, um líquido fictício com viscosidade dinâmica de 1 Pas, densidade de $1000 \mathrm{~kg} / \mathrm{m}^{3}$ e três valores diferentes do tempo de relaxação é considerado. A análise é feita numa faixa de frequência entre 0 e $10 \mathrm{MHz}$, suficiente para abranger as frequências usadas neste trabalho. Os valores de $G_{\infty}$ são selecionados de maneira que para a frequência final de $10 \mathrm{MHz}$ tenhamse valores de 90, 50 e 10\% da viscosidade dinâmica, equivalendo a valores de $G_{\infty}$ de $1,9 \times 10^{8}, 6,3 \times 10^{7}$ e $2,1 \times 10^{7} \mathrm{~Pa}$, respectivamente. O resultado é mostrado na figura 2.5. Quanto menor o valor de $G_{\infty}$, maior o efeito viscoelástico, porque o tempo de relaxação se aproxima do tempo característico do processo de deformação.

Na figura 2.6 são mostradas as componentes do módulo de cisalhamento 
(a)

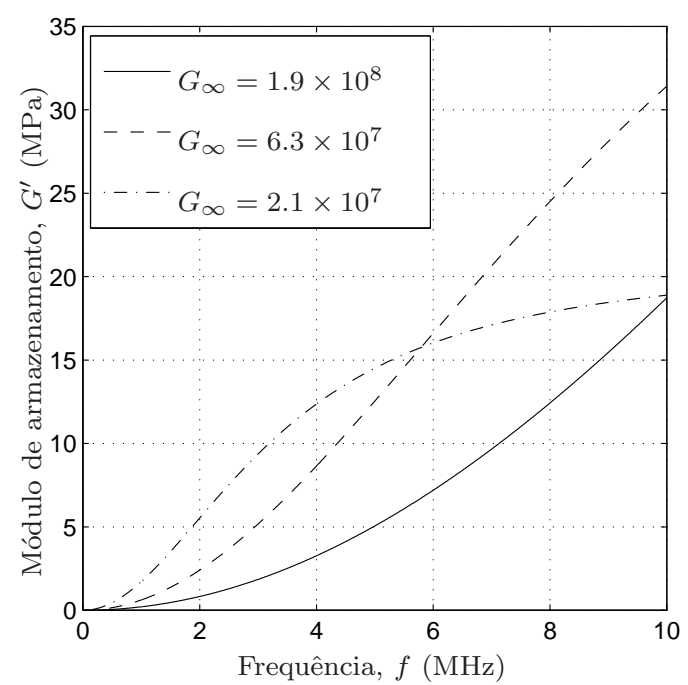

(b)

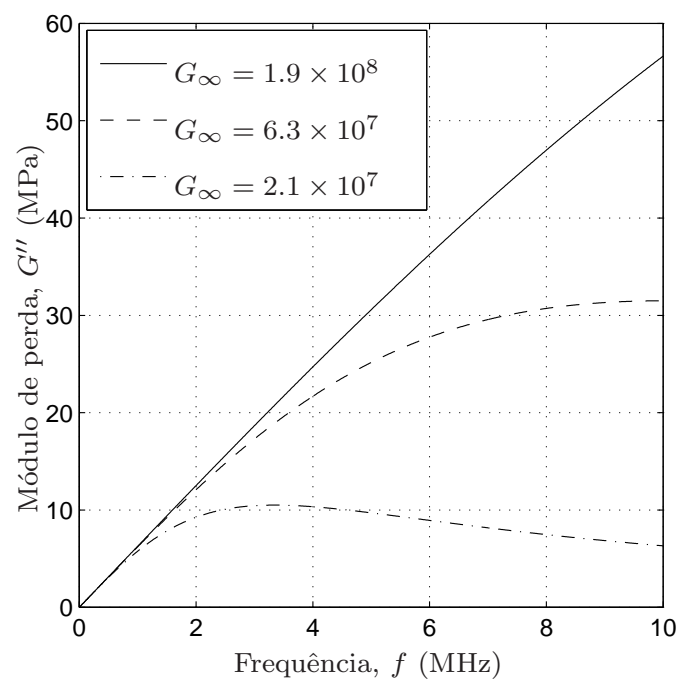

Figura 2.6: Módulos de armazenamento (a) e de perda (b) obtidos com o modelo de Maxwell para um líquido fictício de viscosidade 1,0 Pas, densidade $1000 \mathrm{~kg} / \mathrm{m}^{3}$ e três valores diferentes de $G_{\infty}(\mathrm{Pa})$, com frequências até $10 \mathrm{MHz}$.

complexo para os casos vistos na figura 2.5. No caso do módulo de armazenamento, figura 2.6a, o seu valor aumenta no começo mais rapidamente para valores menores de $G_{\infty}$, ao tempo que o módulo de perda, figura $2.6 \mathrm{~b}$, atinge um valor máximo e começa a decrescer. $\mathrm{O}$ valor da frequência para o valor máximo depende do valor de $G_{\infty}$.

\subsection{Análise das quantidades mensuráveis}

A medição bem sucedida das propriedades viscoelásticas depende da correta determinação do coeficiente de reflexão na interface sólido-líquido. Parâmetros da medição, como sensibilidade e faixa útil, dependem do projeto do dispositivo de medição, principalmente do tipo de material sólido empregado na interface e da frequência de trabalho. As propriedades acústicas da amostra líquida, principalmente sua densidade, também influenciam a medição. Nesta seção, uma análise dos fatores mais importantes a levar em conta no projeto dos dispositivos de medição é feita. Esses fatores são: frequência de operação, material sólido na interface e propriedades da amostra líquida, como densidade e viscosidade.

Na figura 2.7 são mostradas as quantidades mensuráveis, $r$ e $\theta$, na faixa 
(a)

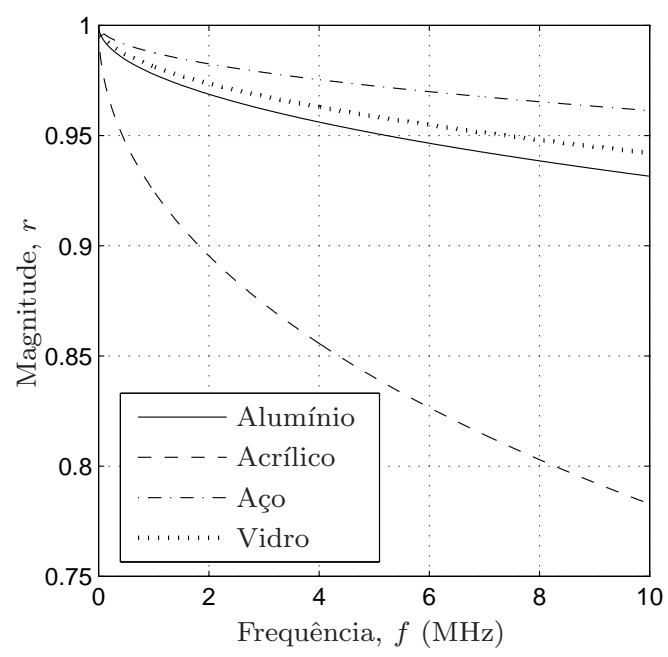

(b)

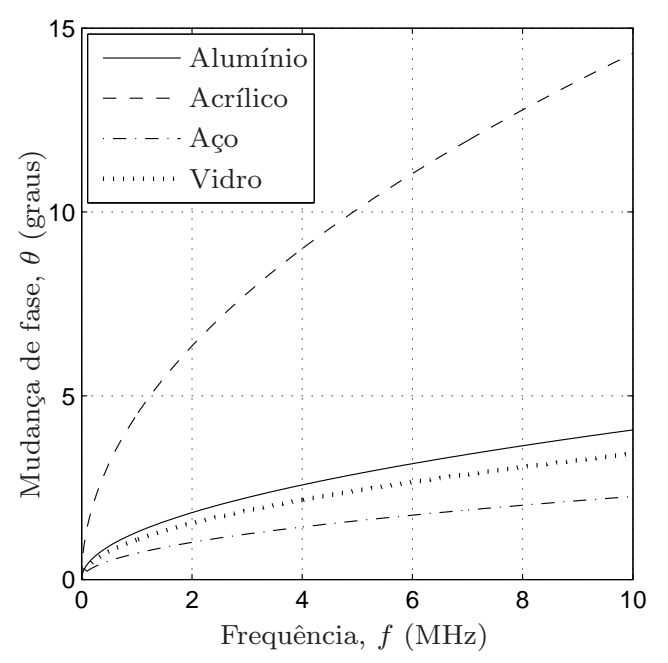

Figura 2.7: Magnitude (a) e mudança de fase (b) do coeficiente de reflexão em função da frequência, para um líquido fictício de viscosidade 1,0 Pas e densidade $1000 \mathrm{~kg} / \mathrm{m}^{3}$, para quatro materiais sólidos na interface de medição, usando o modelo newtoniano.

de frequência menor que $10 \mathrm{MHz}$ para um líquido newtoniano hipotético com viscosidade dinâmica de 1,0 Pas e densidade de $1000 \mathrm{~kg} / \mathrm{m}^{3}$, para quatro sólidos diferentes na interface de medição: alumínio, acrílico, aço e vidro (BK7). O acrílico é o material que fornece melhor sensibilidade, devido ao melhor casamento das impedâncias, que se traduz numa maior transferência de energia ao líquido (SHAH; BALASUBRAMANIAM, 1996). No entanto, o acrílico apresenta a pior resistência, tanto mecânica como ao ataque químico. Isso limita seu uso com solventes e outros líquidos corrosivos. Contudo, o principal problema do acrílico é sua alta atenuação que, na prática, limita a frequência de trabalho a valores menores que, aproximadamente, $3 \mathrm{MHz}$ (FRANCO, 2006).

Na figura 2.8 é mostrado o efeito da densidade do líquido testado sobre as quantidades mensuráveis. Os valores de $r$ e $\theta$ foram simulados, usando o modelo de líquido newtoniano, para três líquidos fictícios de viscosidade 1,0 Pas e diferente densidade. Quando aumenta a densidade da amostra líquida, melhora a sensibilidade do método devido ao melhor casamento das impedâncias que aumenta a energia transmitida ao líquido.

Na figura 2.9 mostra o efeito da frequência de trabalho sobre as quantidades mensuráveis. Os valores de $r$ e $\theta$ em função da viscosidade foram simulados, 
(a)

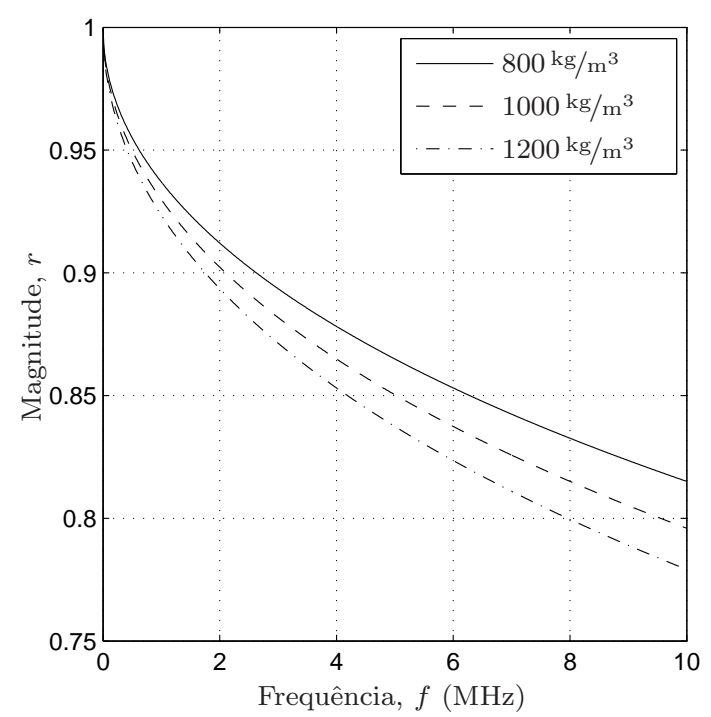

(b)

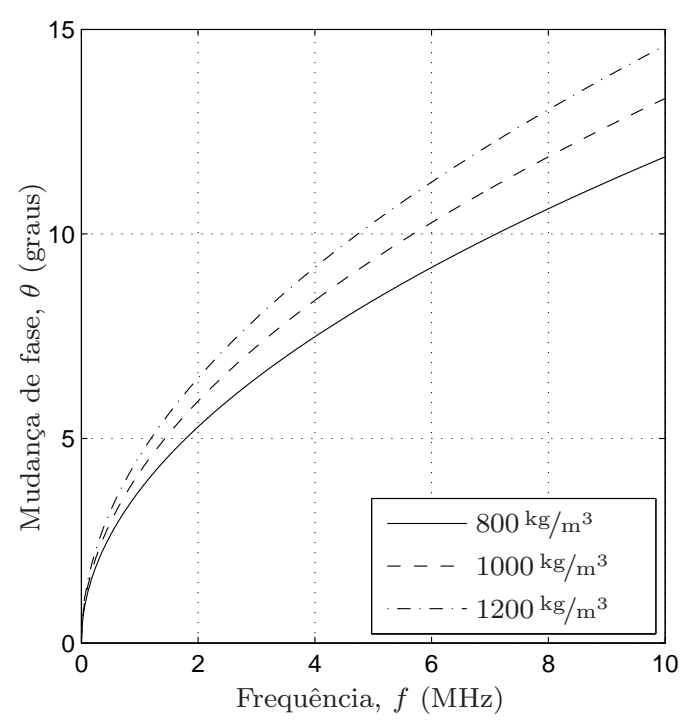

Figura 2.8: Magnitude (a) e mudança de fase (b) do coeficiente de reflexão em função da frequência, para três líquidos fictícios de viscosidade 1,0 Pas e diferente valor de densidade, usando o modelo newtoniano e acrílico como meio sólido.

(a)

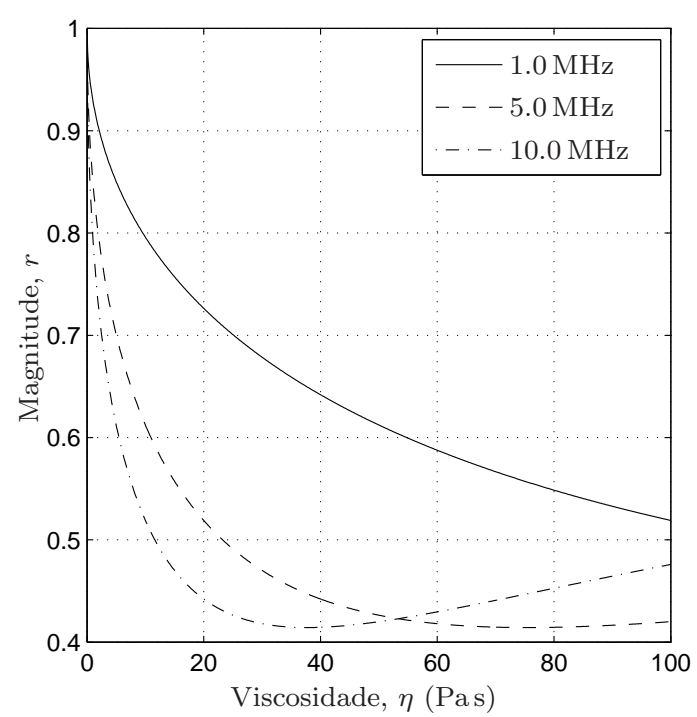

(b)

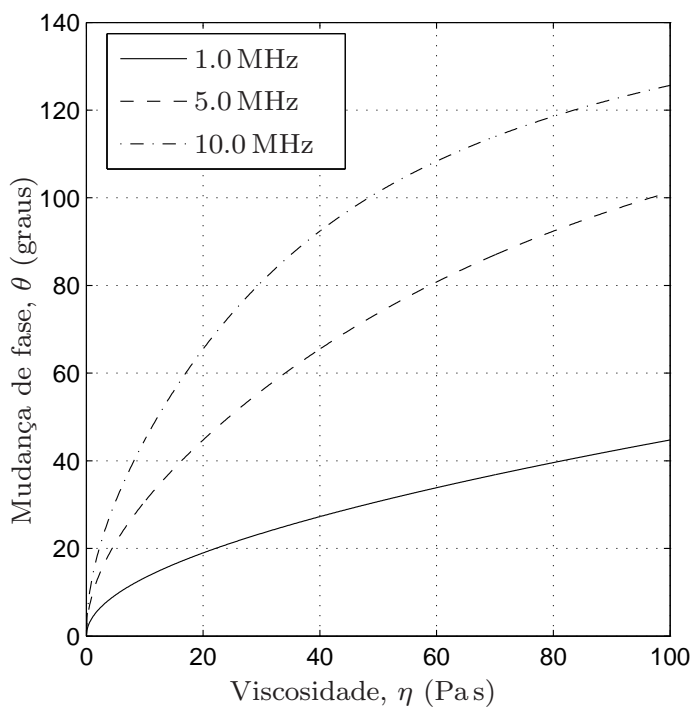

Figura 2.9: Magnitude (a) e mudança de fase (b) do coeficiente de reflexão em função da viscosidade, para três frequências de trabalho, usando o modelo newtoniano e acrílico como meio sólido. 
(a)

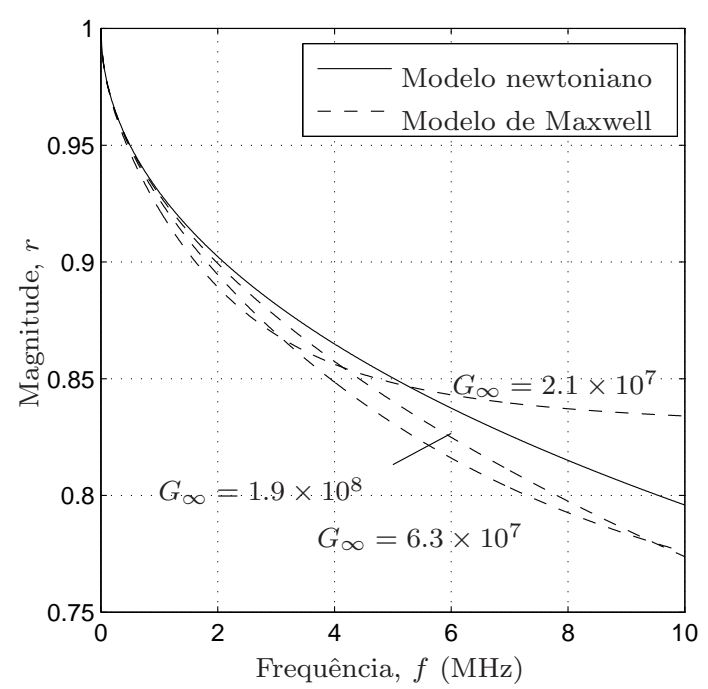

(b)

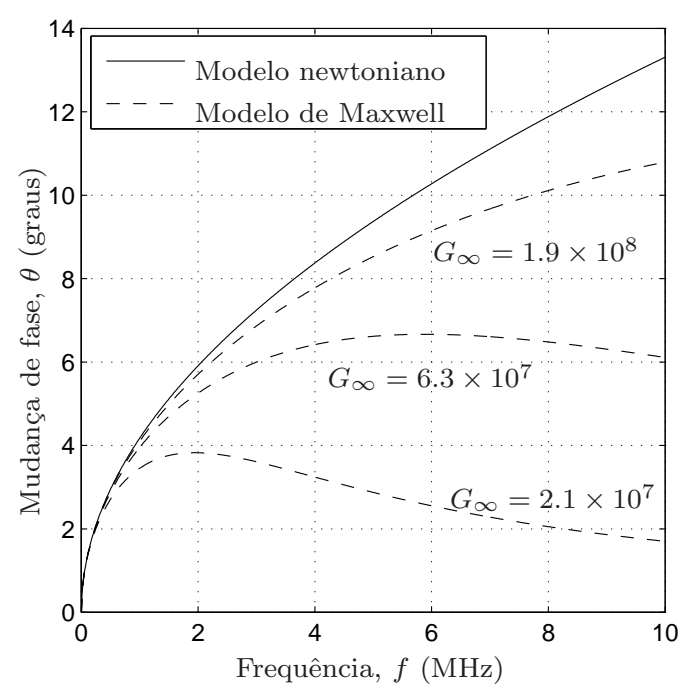

Figura 2.10: Valores de magnitude (a) e mudança de fase (b) em função da frequência fornecidos pelos modelos newtoniano e de Maxwell, com três valores diferentes de $G_{\infty}(\mathrm{Pa})$.

usando o modelo newtoniano, para um liquido fictício de densidade $1000 \mathrm{~kg} / \mathrm{m}^{3}$ a três diferentes frequências de trabalho. Como esperado, a sensibilidade aumenta com a frequência. Contudo, a atenuação limita a frequência de trabalho a alguns mega-hertz, principalmente no caso de dispositivos de incidência normal onde várias linhas de retardo diferentes são usadas. A magnitude do coeficiente de reflexão apresenta um valor mínimo de, aproximadamente, 0,42. No entanto, esse valor mínimo é muito difícil de ser observado experimentalmente.

A figura 2.10 mostra a influência da viscoelasticidade sobre as quantidades mensuráveis. Os valores de $r$ e $\theta$ foram plotados para um líquido fictício de 1,0 Pas, em função da frequência, usando o modelo de Maxwell com os mesmos três valores de $G_{\infty}$ usados na subseção 2.7 .2 e comparados aos valores fornecidos pelo modelo de líquido newtoniano. O efeito viscoelástico aumenta levemente a sensibilidade na medição do $r$, e reduz drasticamente a do $\theta$, na faixa de frequência investigada $(0-10 \mathrm{MHz})$. No caso do $r$, as linhas dos diferentes valores de $G_{\infty}$ se cruzam, podendo levar a problemas na medição. Por exemplo, para os dois valores menores de $G_{\infty}$ e para a frequência de, aproximadamente, $3 \mathrm{MHz}$, o valor de $r$ é o mesmo. Por outro lado, o efeito viscoelástico afeta drasticamente o $\theta$ que apresenta um valor máximo e depois continua decrescendo monotonicamente, com a frequência, até atingir o valor de zero no infinito. Levando em conta 


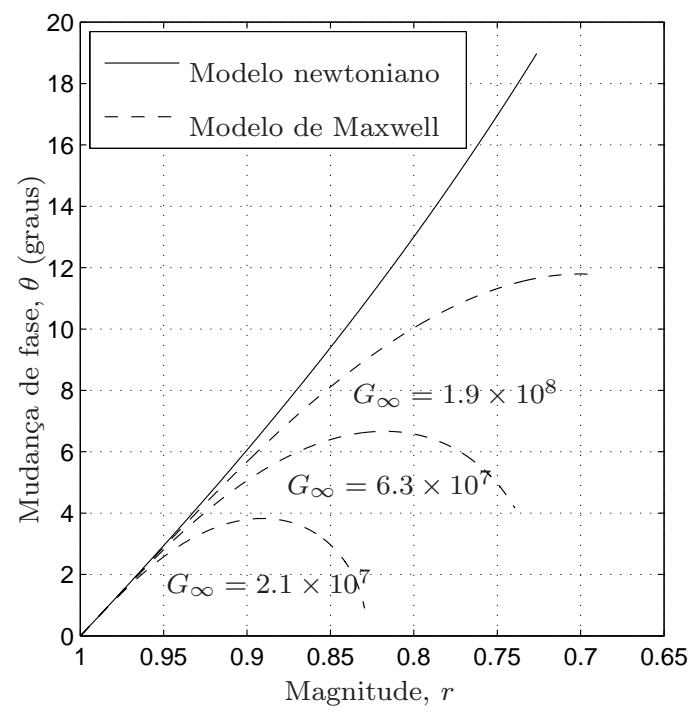

Figura 2.11: Mudança de fase plotada em função da magnitude para o modelo newtoniano e o modelo de Maxwell, para três valores de $G_{\infty}$

que o modelo de Maxwell para materiais viscoelásticos é um dos mais simples, os resultados obtidos mostram um comportamento complicado das quantidades mensuráveis em regime não-newtoniano.

Como mostrado, as quantidades mensuráveis, $r$ e $\theta$, dependem das propriedades viscoelásticas do líquido testado. No caso de um líquido newtoniano pode-se medir somente $r$ e obter o valor de $\theta$ a partir da equação 2.36 , sendo que, para o caso contrário, também é possível medir $\theta$ e calcular $r$ a partir da equação 2.38. Isso significa que $r$ e $\theta$ estão desacoplados (SHAH; BALASUBRAMANIAM, 2000) e a dependência que têm um do outro é conhecida. No caso onde o efeito viscoelástico aumenta e o comportamento afasta-se do newtoniano, a dependência que as quantidades mensuráveis têm uma da outra é mais complexa e, em geral, desconhecida.

Na figura 2.11 são plotados os valores esperados de $\theta$ em função dos valores de $r$, para os mesmos casos mostrados na figura 2.4. A linha sólida, calculada a partir do modelo newtoniano, usando a equação 2.36, define duas regiões. A região definida pela área que fica embaixo da linha representa uma zona de valores de $r$ e $\theta$ que levam a valores positivos de elasticidade. Nessa região tem-se comportamento viscoelástico. Pode-se ver que no caso do modelo de Maxwell, a mudança de fase aumenta até atingir um valor máximo. Isso significa que o mesmo valor de $\theta$ pode ser obtido para dois valores diferentes de $r$. A região acima da linha do modelo newtoniano leva a valores negativos da elasticidade, 
valores que não fazem sentido físico. 


\section{Metodologia experimental}

Neste capítulo são abordados todos os temas relativos à metodologia experimental, começando pela descrição detalhada dos dispositivos de medição desenvolvidos e a técnica de medição do coeficiente de reflexão empregada. $\mathrm{Na}$ sequência são detalhados os métodos usados na caracterização das amostras líquidas testadas e os sólidos da interface de medição. Finalmente, o método de análise dos resultados experimentais obtidos é apresentado.

\subsection{Células de medição}

A geração das ondas de cisalhamento é fundamental no método de medição e a maneira como isso é feito influencia fortemente o projeto dos dispositivos de medição. Basicamente existem duas maneiras de gerar ondas de cisalhamento: conversão de modo e transdutores de cisalhamento. Com base na experiência do autor no projeto desse tipo de dispositivos, a conversão de modo proporciona ondas de cisalhamento mais puras. Já os transdutores de cisalhamento, mesmo não gerando uma onda muito limpa, permitem um projeto mais simples e robusto (FRANCO, 2006). Nesta seção são apresentadas as células de medição desenvolvidas mostrando suas características mais relevantes, assim como as vantagens e desvantagens inerentes a cada uma.

\subsubsection{Célula com conversão de modo (CCM)}

No fenômeno de conversão de modo, as ondas de cisalhamento são geradas a partir de ondas longitudinais que incidem obliquamente na interface entre dois meios de diferente impedância acústica. As ondas longitudinais propagam-se numa linha de retardo líquida até atingirem a face oblíqua de um prisma sólido de alumínio, aço ou outro metal com baixa atenuação. Se o ângulo de incidência é maior que o ângulo crítico das ondas longitudinais nessa interface, somente ondas 
(a)

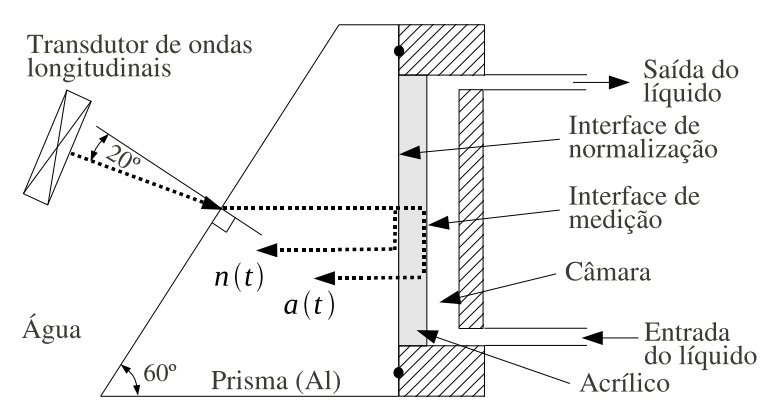

(b)

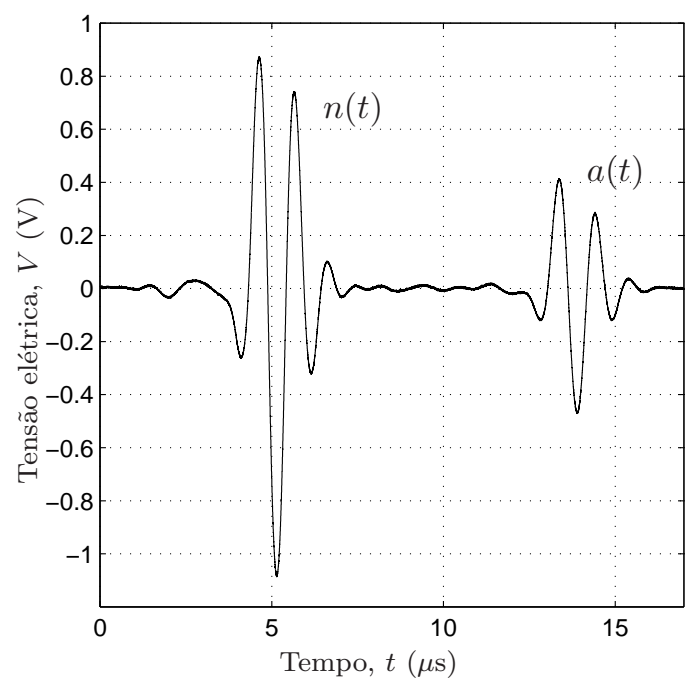

(c)

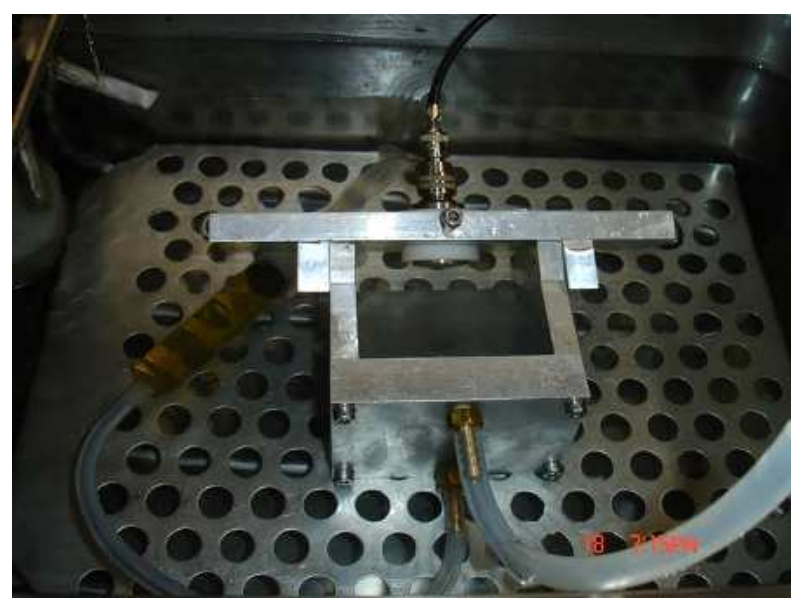

Figura 3.1: Células de medição com conversão de modo (CCM): esquema da montagem (a), sinal adquirido (b) e imagem da célula no banho termostático (c).

de cisalhamento são transmitidas ao prisma. Em geral, a conversão de modo é um fenômeno complicado e difícil de modelar matematicamente, pode-se achar informação mais detalhada do tema num trabalho prévio do autor (FRANCO et al., 2005).

A figura 3.1a mostra um esquema da célula de medição constituída por um transdutor de ondas longitudinais, um prisma de alumínio, uma linha de retardo de acrílico e uma câmara para a amostra. A amostra líquida é introduzida na câmara por uma entrada localizada na tampa, que é vedada, havendo também 
uma saída para o ar e o excesso de líquido. O transdutor emite uma onda longitudinal que se propaga na linha de retardo de água e atinge a face inclinada do prisma de alumínio. Nesse ponto acontece a conversão de modo total, devido ao ângulo de incidência escolhido, transmitindo somente uma onda de cisalhamento ao alumínio. A onda de cisalhamento propaga-se no prisma e atinge as interfaces alumínio-acrílico, gerando a reflexão $n(t)$, e alumínio-amostra, gerando a reflexão $a(t)$. As reflexões fazem o caminho inverso sendo detectadas pelo mesmo transdutor em modo longitudinal. Na figura 3.1b são mostrados dois ecos refletidos. Uma imagem da célula dentro do banho termostático é mostrada na figura 3.1c. Podem-se ver o transdutor de 25,4 mm de diâmetro montado na célula e a amostra líquida numa seringa de $20 \mathrm{ml}$, também dentro do banho termostático, pronta para ser injetada na câmara.

Transdutores comerciais de ondas longitudinais com frequências de 1,0, 2,25 e 3,5 MHz e $25.4 \mathrm{~mm}$ de diâmetro (Panametrics V314, V305 e A381S, Olympus NDT, Kennewick, WA, EUA) foram usados nessa célula. Transdutores de frequências menores que 1,0 MHz não podem ser usados devido à sobreposição dos ecos $n(t)$ e $a(t)$. Já os de frequências maiores que 3,5 MHz não são usados devido à alta atenuação no acrílico que ocasiona amplitudes muito pequenas do eco $a(t)$, quando comparadas com as do eco $n(t)$, ocasionando perda de resolução. Portanto, a frequência do ensaio foi limitada aqui a 1,0 $\mathrm{MHz}$, que mostrou melhores resultados em trabalhos anteriores (FRANCO, 2006).

A primeira célula de medição com conversão de modo foi desenvolvida no Laboratório de Ultrassom do Departamento de Engenharia Mecatrônica da EPUSP no final da década de noventa (BUIOCHI.; ADAMOWSKI; FURUKAWA, 1998). O projeto inicial usava, na recepção, transdutores de grande abertura feitos com membrana piezelétrica de PVDF para reduzir os efeitos de difração. No trabalho de mestrado do autor (FRANCO, 2006), a recepção foi feita pelo mesmo transdutor comercial usado para emissão e a célula passou a funcionar no modo pulso-eco. Os problemas de difração foram eliminados pela técnica de normalização dos sinais, explicada na seção 3.2. Entre as vantagens e desvantagens, apresentadas por essas células de medição com conversão de modo, têm-se: 
Vantagens:

- Geram ondas de cisalhamento mais puras (menos onda longitudinal parasita)

- Utilizam transdutores de ondas longitudinais que são relativamente mais baratos que os transdutores de cisalhamento.

- Permitem realizar testes numa faixa de frequência mais ampla.
Desvantagens:

- Fabricação mais complicada.

- Dispositivo menos robusto devido à linha de retardo líquida.

- Dependência do ângulo de refração com a temperatura.

- Maior caminho percorrido pelas ondas.

Essas células de medição cumpriram um papel importante para o melhor entendimento dos fenômenos físicos envolvidos no método de medição. Os resultados obtidos foram publicados em vários congressos e periódicos, sendo que dois deles em revistas internacionais (BUIOCHI et al., 2006; FRANCO et al., 2008b). No entanto, as desvantagens mostradas acima dificultam o uso desse tipo de célula em aplicações externas ao ambiente de laboratório.

\subsubsection{Células com transdutores de cisalhamento (CTC)}

As células de medição que usam transdutores na geração direta de ondas de cisalhamento são constituídas, geralmente, por duas linhas de retardo sólidas. A segunda linha de retardo é necessária somente para se ter uma interface sólidosólido, que gera o eco usado na normalização dos sinais. Algumas das vantagens e desvantagens apresentadas por esse tipo de célula de medição são:

Vantagens:

- Menor distância percorrida pelas ondas.

- Dispositivo robusto e de fácil fabricação.

- Não trabalham em imersão.
Desvantagens:

- Os transdutores de cisalhamento geram ondas longitudinais parasitas, junto com as ondas de cisalhamento, que podem induzir erros na medição.

- Os transdutores de ondas de cisalhamento são caros e fabricados numa pequena gama de frequências.

A célula de medição (CTC), mostrada na figura 3.2a, é composta de um transdutor de ondas de cisalhamento de $1 \mathrm{MHz}$ e $25 \mathrm{~mm}$ de diâmetro 
(Krautkramer B1-Y, GE Sensing and Inspection Technologies, Fairfield-CT, EUA), uma linha de retardo de alumínio, uma linha de retardo de acrílico e uma câmara da amostra idêntica à usada na célula com conversão de modo. $\mathrm{O}$ transdutor de cisalhamento gera uma onda que se propaga na linha de retardo de alumínio. Quando a onda atinge a interface alumínio-acrílico, uma parte é refletida $(n(t))$ e a outra parte propaga-se no acrílico e é refletida pela interface acrílico-amostra $(a(t))$. Ambas as reflexões são recebidas pelo mesmo transdutor, que funciona em modo pulso-eco. Na figura 3.2b é mostrada uma aquisição onde podem-se ver os ecos refletidos $n(t)$ e $a(t)$. O eco que aparece depois de $a(t)$ corresponde à segunda reflexão dentro do alumínio. Duas imagens da célula são mostradas nas figura 3.2c e 3.2d. Na primeira imagem, a célula está desmontada e pode-se ver a linha de retardo de acrílico; na segunda, a célula é mostrada no banho junto com a amostra que foi injetada.

Como as ondas de cisalhamento propagam-se distâncias muito pequenas num líquido, não é possível usar acoplantes como água ou vaselina entre o transdutor e o alumínio. Portanto, o transdutor precisa estar colado e isso deve ser feito cuidadosamente para se manter a integridade do transdutor e afetar o mínimo possível a geração das ondas. Foram testados diferentes tipos de adesivos, como cera de abelha e Araldite, entre outros. A cera de abelha funde a relativamente baixa temperatura $\left(62^{\circ} \mathrm{C}\right)$ e permite colar e descolar o transdutor com facilidade e sem perigo de danificá-lo. No entanto, é pouco rígida e atenua muito as ondas. Já o Araldite apresenta boa rigidez, mas descolar e limpar o transdutor é muito difícil. A opção escolhida foi um adesivo com características intermediárias, composto por cianocrilato (Super Bonder, Loctite).

\subsection{Determinação experimental do coeficiente de reflexão}

O coeficiente de reflexão é uma grandeza complexa, cuja magnitude $r$ e fase $\theta$ estão relacionadas com a variação de amplitude e a defasagem, respectivamente, da onda de cisalhamento refletida pela interface sólido-líquido com respeito a outra refletida pela interface sólido-ar. No caso da interface sólido-ar, tem-se a reflexão total $\left(r=1\right.$ e $\left.\theta=180^{\circ}\right)$, fornecendo a referência usada na determinação da variação do coeficiente. Teoricamente uma reflexão completa somente ocorre quando o sólido está em contato com o vácuo. No entanto, a impedância acústica 
(a)

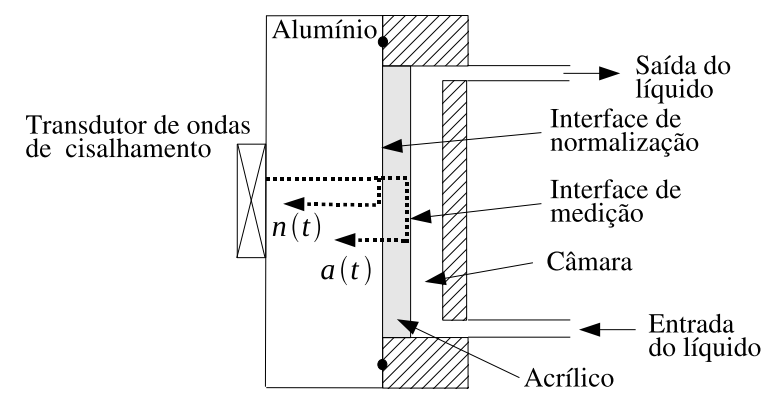

(c)

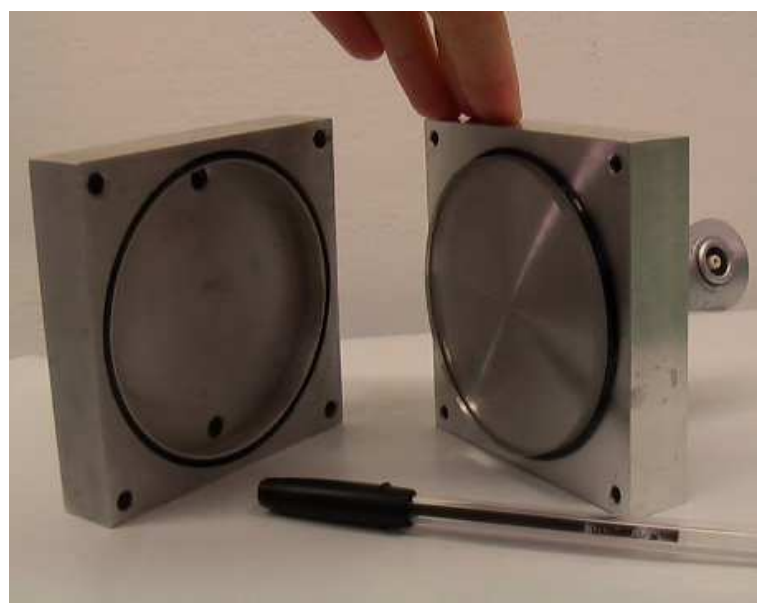

(b)

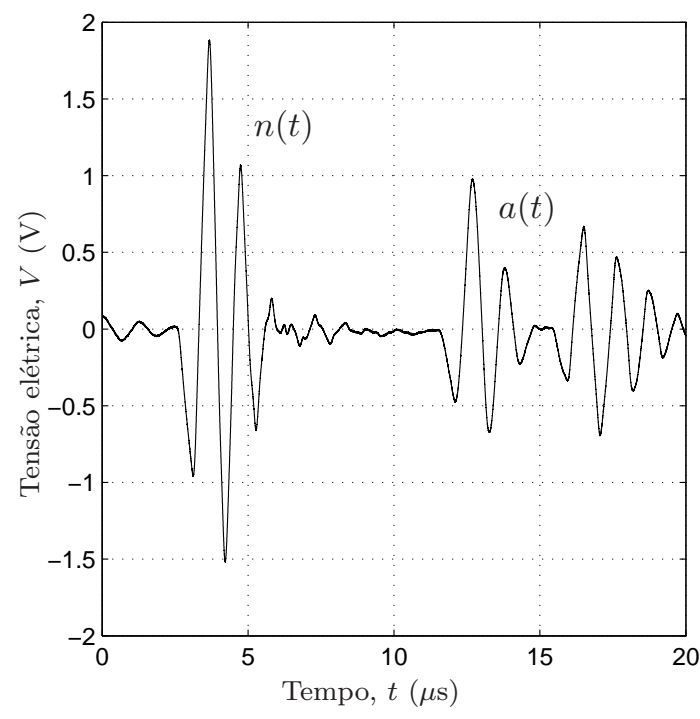

(d)

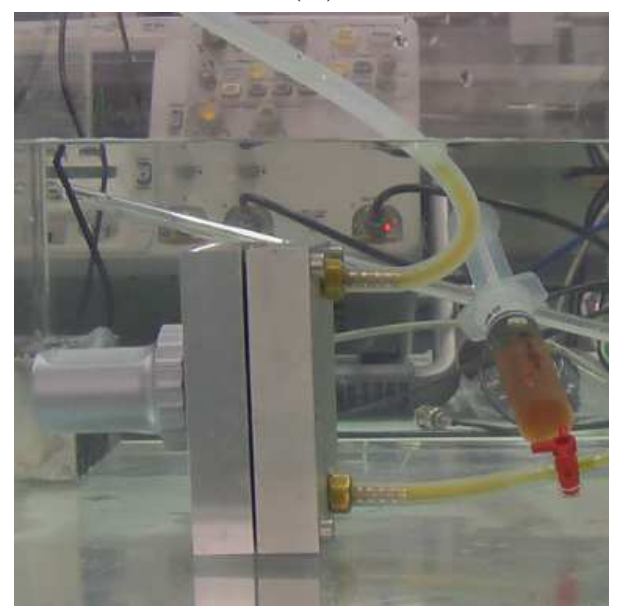

Figura 3.2: Célula de medição que usa ondas de cisalhamento geradas diretamente por um transdutor comercial (CTC): esquema (a), sinal obtido (b), imagem da célula aberta (c) e imagem da célula no banho (d).

do ar é muito pequena quando comparada com a do líquido. Assim, pode-se considerar que a reflexão na interface sólido-ar é completa.

A medição do coeficiente de reflexão é influenciada por fatores externos, como gradientes de temperatura nas linhas de retardo, instabilidades na eletrônica, entre outros. Isso faz com que a simples comparação dos ecos refletidos na interface de medição $(a(t))$ leve a resultados pouco satisfatórios. Para solucionar esse problema usou-se a normalização dos sinais medidos em relação aos sinais refletidos pela interface sólido-sólido $(n(t))$ (FRANCO, 2006; BUIOCHI, 2000). 


\subsubsection{Técnica da frequência central}

Se $N(f)$ e $A(f)$ são, respectivamente, as transformadas de Fourier dos sinais $n(t)$ e $a(t)$, mostrados nas figuras $3.1 \mathrm{~b}$ e $3.2 \mathrm{~b}$, a magnitude do coeficiente de reflexão é:

$$
r=\frac{\left|A_{l i q}\left(f_{i}\right)\right|\left|N_{a r}\left(f_{i}\right)\right|}{\left|A_{a r}\left(f_{i}\right)\right|\left|N_{l i q}\left(f_{i}\right)\right|}
$$

onde $f=f_{i}$ é a frequência de interesse que geralmente é a frequência central do pulso refletido na interface de medição, e

$$
\theta=\varphi_{l i q}\left(f_{i}\right)-\psi_{l i q}\left(f_{i}\right)-\varphi_{a r}\left(f_{i}\right)+\psi_{a r}\left(f_{i}\right)
$$

onde $\varphi\left(f_{i}\right)=\arg \left\{A\left(f_{i}\right)\right\}$ e $\psi\left(f_{i}\right)=\arg \left\{N\left(f_{i}\right)\right\}$, e os subscritos liq e ar referem-se aos casos com e sem amostra, respectivamente (COHEN-TENOUDJI et al., 1987).

Essa técnica permite calcular o coeficiente de reflexão em função da frequência. No entanto, somente uma faixa ao redor da frequência central do pulso tem a relação sinal-ruído suficiente para obter resultados coerentes (BUIOCHI, 2000).

\subsubsection{Técnica da banda de frequência}

Uma nova técnica que realiza o cálculo numa faixa de frequência, foi desenvolvida neste trabalho, sendo uma contribuição importante ao tema. A seguinte equação é usada no lugar da equação (3.1):

$$
r=\frac{\int_{f_{a}}^{f_{b}}\left|A_{l i q}(f)\right|\left|N_{l i q}(f)\right|^{-1} d f}{\int_{f_{a}}^{f_{b}}\left|A_{a r}(f)\right|\left|N_{a r}(f)\right|^{-1} d f}
$$

onde

$$
f_{a}=(1-\beta) f_{c} \quad \text { e } \quad f_{b}=(1+\beta) f_{c}
$$

definem uma banda de frequência centrada em $f_{c}$ e com largura $2 \beta f_{c}$. O parâmetro $\beta(0 \leq \beta \leq 1)$ define a largura da banda. Nota-se que a equação (3.3) tende à equação (3.1) quando $\beta \rightarrow 0$.

Na equação (3.3) o numerador e o denominador são a área embaixo da curva da amplitude normalizada $(|A(f)| /|N(f)|)$ nos casos com amostra líquida e com 
ar na interface de medição, respectivamente. A magnitude é o quociente dessas duas áreas. Essa técnica é menos sensível ao ruído aleatório próprio do sistema de medição. Uma técnica similar foi usada para melhorar a precisão na medição da densidade de líquidos por ultrassom (HIGUTI; ADAMOWSKI, 2002).

No capítulo 4 são apresentados os resultados experimentais que mostram as vantagens da técnica da banda de frequência e ao mesmo tempo explicam o pouco sucesso obtido com a técnica da frequência central.

\subsubsection{Procedimento experimental}

O fator mais importante na medição do coeficiente de reflexão complexo é a temperatura. Além das propriedades viscoelásticas serem dependentes da temperatura, a propagação da onda é fortemente afetada, mudando a velocidade de propagação e a impedância acústica nas linhas de retardo das células de medição. Isso afeta o coeficiente de reflexão, sendo que uma mudança de alguns décimos de grau Celsius produz uma ligeira mudança na magnitude, principalmente devido à variação na impedância acústica do material sólido em contato com a amostra líquida. Já no caso da fase, a mesma variação de temperatura ocasiona uma forte mudança, geralmente da mesma ordem de grandeza da fase esperada pela presença do líquido. Então, um banho termostático com controle preciso da temperatura de $\pm 0,1^{\circ} \mathrm{C}$ ou menor é necessário. No entanto, quando o teste é realizado à temperatura ambiente, um banho termostático sem controle de temperatura localizado numa sala com ar-condicionado é uma boa opção. Como a temperatura da água varia muito lentamente, o ensaio pode ser feito num pequeno espaço de tempo com excelentes resultados. Todos os ensaios a temperatura ambiente deste trabalho foram realizados dessa maneira. Uma análise detalhada dos efeitos da temperatura sobre a medição pode ser achada na dissertação de mestrado do autor (FRANCO, 2006).

Devem-se levar em conta a resolução vertical e a taxa de amostragem do sistema de aquisição, principalmente pela restrição no tempo de ensaio e pela limitação na velocidade de transferência dos dados do digitalizador para o computador. A medição da magnitude requer uma boa resolução vertical, porém o digitalizado usado é de apenas 8 bits, de forma que o sinal adquirido precisa ser a média de muitos sinais individuais. Esse número de sinais individuais foi de 32 no 
mínimo. Foram usadas taxas de amostragem temporal de $571 \mathrm{MHz}$ e $1.33 \mathrm{GHz}$ que, mesmo sendo altas, não alcançam a máxima capacidade do digitalizador. No caso da fase, como a resolução temporal é mais importante que a resolução vertical, foi usada uma taxa de amostragem de $4 \mathrm{GHz}$, a máxima fornecida pelo digitalizador e uma única aquisição, ou seja, sem médias.

O procedimento usado para medir a magnitude e a fase no mesmo ensaio é apresentado no seguinte quadro:

1. A célula de medição junto com a amostra líquida são imersas no banho termostático e espera-se um tempo mínimo de uma hora para a homogeneização da temperatura.

2. São feitas as medidas de referência com ar:

(a) 5 aquisições a $571 \mathrm{MHz}$ e 32 médias.

(b) 5 aquisições a $4 \mathrm{GHz}$ sem médias.

3. A amostra líquida é injetada na célula no menor tempo possível.

4. São feitas as medidas com a amostra líquida:

(a) 5 aquisições a $4 \mathrm{GHz}$ sem médias.

(b) 5 aquisições a $571 \mathrm{MHz}$ e 32 médias.

As aquisições feitas nos passos 2a e 4b são usadas para calcular a magnitude e as feitas nos passos $2 \mathrm{~b}$ e $4 \mathrm{a}$ para calcular a fase. Esse enfoque permite fazer as aquisições para a fase num curto espaço de tempo, e as aquisições para a magnitude com a quantidade de médias necessárias para se obter uma boa resolução vertical. Fica claro que cada grandeza também pode ser medida separadamente, se preciso. Finalmente, um rigoroso processo de limpeza da célula e das mangueiras é realizado ao final de cada teste, com a finalidade de evitar a contaminação da amostra e de proteger o acrílico de possíveis ataques químicos.

Como as células de medição trabalham em modo pulso-eco, o arranjo experimental é constituído de um pulsador/receptor (Panametrics 5077PR, Olympus NDT, Kennewick, WA, EUA), um osciloscópio (Agilent DSO6052A, Agilent Technologies, Santa Clara, CA, EUA), que funciona como digitalizador, e um computador. Os dados das aquisições são transferidos através da interface LAN com conexão direta por um cabo entre o osciloscópio e o computador. Os dados são processados posteriormente usando programas implementados em Matlab (Mathworks, Natick, MA, EUA). Um esquema do arranjo experimental é mostrado na figura 3.3. 


\subsubsection{Análise dos sinais}

A magnitude e a fase têm um significado físico claro no domínio do tempo. Por conseguinte, métodos de análise de sinais no tempo, como o cálculo da envoltória, por exemplo, parecem apropriados. No entanto, resultados experimentais mostraram que o cálculo no domínio da frequência fornece melhores resultados (FRANCO, 2006).

Na teoria apresentada na seção 3.2.1, a transformada de Fourier de 4 pulsos deve ser calculada. Devido às altas taxas de amostragem usadas e levando-se em conta que são 2 ecos em cada aquisição e 10 aquisições no total, o tempo de processamento da transformada é considerável. Por isso as transformadas de Fourier são calculadas somente na frequência de interesse usando o algoritmo Goertzel fornecido em Matlab. O espectro completo somente é calculado uma única vez para cada ensaio, determinando a frequência central dos pulsos e as frequências que limitam uma largura de banda de $-3 \mathrm{~dB}$.

O cálculo começa delimitando os 4 ecos em janelas temporais apropriadas e centrando-os verticalmente no zero, subtraindo do sinal o seu valor médio. Depois são calculadas as transformadas de Fourier de todos os pulsos na frequência de interesse, que geralmente é a frequência central do pulso que retorna da interface de medição no caso com a amostra líquida. Finalmente, são calculados os valores de magnitude e fase usando as equações (3.1) e (3.2).

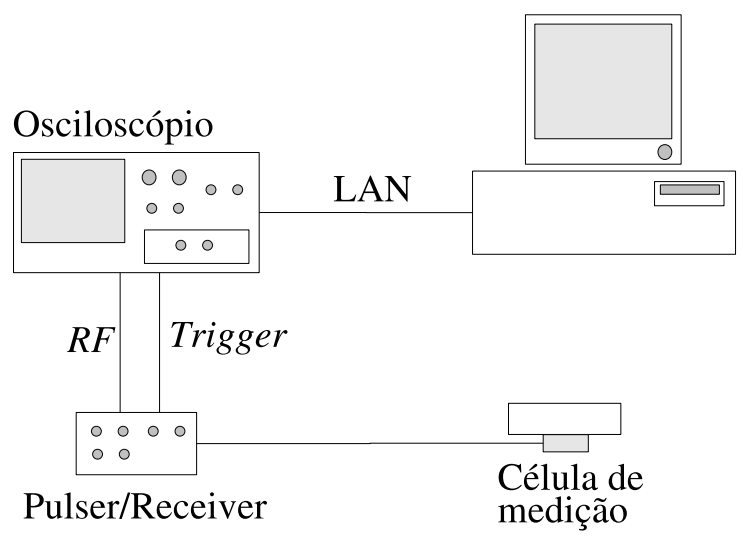

Figura 3.3: Arranjo experimental usado. 


\subsection{Propriedades físicas dos líquidos testados}

Neste trabalho, a densidade precisa ser conhecida a priori para calcular a viscosidade e a elasticidade por ultrassom. Além disso, a viscosidade dinâmica é requerida como uma base de comparação dos resultados. As propriedades físicas são mostradas na tabela 3.1 .

A densidade foi medida usando um picnômetro de $50 \mathrm{ml}$ (Brand $\mathrm{GmbH}$, Wertheim, Alemanha) calibrado com precisão de $0,001 \mathrm{~cm}^{3}$. A medição foi feita a temperatura ambiente, aproximadamente $20^{\circ} \mathrm{C}$, e a densidade foi considerada constante na faixa de temperatura usada neste trabalho $\left(15-25^{\circ} \mathrm{C}\right)$.

A viscosidade dinâmica ou a viscosidade medida a baixa frequência, indispensável como base de comparação dos resultados, foi medida com o viscosímetro rotacional Rheotest 2.1 (MLW, Mendingen, Alemanha). Foram realizadas medidas na faixa entre 15 e $25^{\circ} \mathrm{C}$ a intervalos de $2,5^{\circ} \mathrm{C}$ e os resultados foram ajustados usando polinômios de segunda ordem. Para cada medição individual, foram feitas um mínimo de três medições a diferentes taxas de cisalhamento para gerar curvas de fluxo (tensão de cisalhamento vs. taxa de cisalhamento). As taxas de cisalhamento foram escolhidas baixas o suficiente para assegurar regime Newtoniano, o que foi comprovado pela obtenção nas curvas de fluxo de retas que cruzam a origem. A viscosidade final foi obtida a partir da inclinação da reta ajustada aos dados medidos. O viscosímetro possui controle de temperatura por meio de um banho termostático com precisão de $\pm 0,1^{\circ} \mathrm{C}$.

Na figura 3.4 são mostrados os resultados da medição da viscosidade dinâmica da glicerina em função da temperatura, usando o viscosímetro rotacional. A figura 3.4a mostra as curvas de fluxo para cada temperatura. A figura 3.4b mostra os resultados de viscosidade, média e desvio padrão, e o polinômio ajustado. Os erros inerentes à medição com o viscosímetro rotacional não são levados em conta na comparação dos resultados por ultrassom. Contudo, o viscosímetro usado é um aparelho confiável e testado anteriormente com água destilada para comprovar sua calibração.

É muito interessante dispor de amostras de viscosidade variável e ao mesmo tempo com estrutura atômica similar. Para esse propósito, uma mistura de água e algum líquido viscoso solúvel em água é uma boa opção, sendo que a glicose de milho, principalmente composta de glicose $\left(\mathrm{C}_{6} \mathrm{H}_{12} \mathrm{O}_{6}\right)$, é uma excelente 
(a)

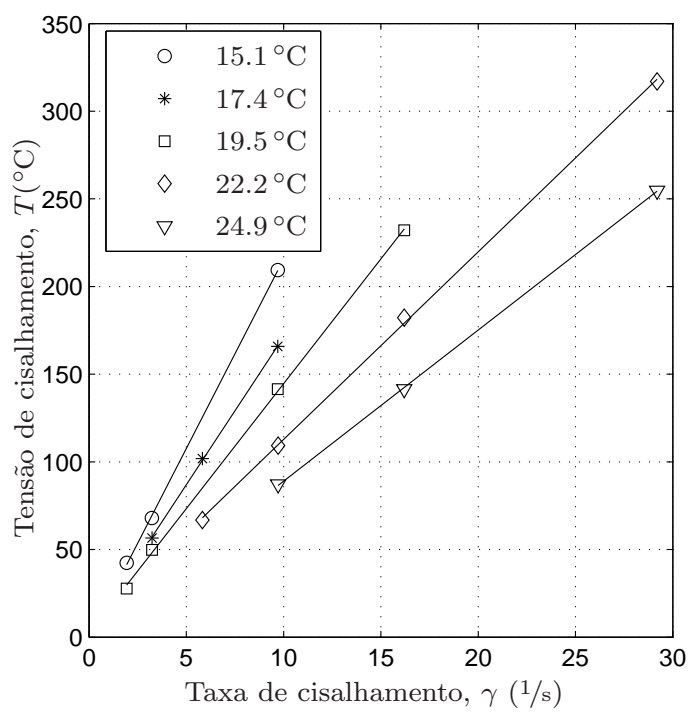

(b)

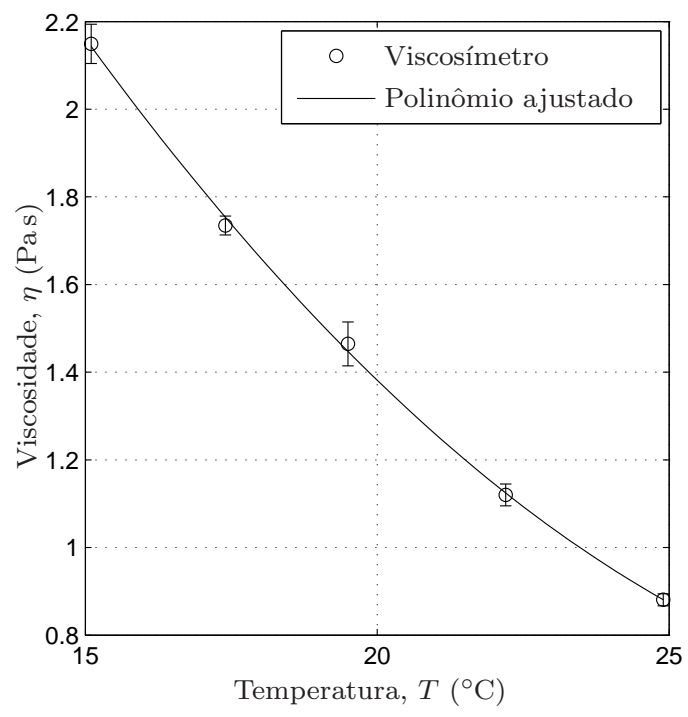

Figura 3.4: Medição da viscosidade dinâmica $\left(\eta_{0}\right)$ da glicerina em função da temperatura usando o viscosímetro rotacional Rheotest 2.1: curvas de fluxo (a) e resultados de viscosidade (b).

opção pela sua disponibilidade e fácil manuseio. Foi adquirido num supermercado aproximadamente um litro de uma marca comercial de glicose de milho (Karo, Unilever Brasil Alimentos Ltda.) e misturada com água destilada, de maneira a se ter uma série de amostras com concentrações de glicose entre 70 e 100\% em peso.

A densidade da mistura foi obtida a partir da densidade da glicose de milho pura, medida com picnômetro, e da densidade teórica da água destilada à temperatura de interesse. Os valores de densidade para as diferentes concentrações foram calculados usando a seguinte relação:

$$
\rho(\xi)=\rho_{g} \xi+\rho_{a}(1-\xi)
$$

onde $\rho_{g}$ e $\rho_{a}$ são as densidades da glicose de milho pura e da água destilada, respectivamente, e $\xi$ é a fração de massa de glicose. Nos gráficos de resultados, no lugar da fração de massa, vai ser usada a porcentagem de massa. A viscosidade de todas as amostras foi medida numa única temperatura $\left(19,5 \pm 0,2^{\circ} \mathrm{C}\right)$ e os testes por ultrassom foram feitos nessa mesma temperatura. As propriedades físicas das amostras são mostradas na tabela 3.2. 
Tabela 3.1: Propriedades físicas dos líquidos testados.

\begin{tabular}{|l|l|c|c|}
\hline Líquido & Descrição & $\rho\left(\mathrm{kg} / \mathrm{m}^{3}\right)$ & $\eta(T)(\mathrm{Pas})^{1}$ \\
\hline \hline Azeite de oliva & $\begin{array}{l}\text { Nome comercial: Rivoli } \\
\text { Extra virgem. Fornece- } \\
\text { dor: Agro Aceitunera } \\
\text { S.A., Argentina. }\end{array}$ & 882 & $1,706 \times 10^{-4} T^{2}-0,011 T+0,213$ \\
\hline Glicerina & $\begin{array}{l}\text { Glicerina U.S.P. } \\
\left(\mathrm{C}_{3} \mathrm{H}_{8} \mathrm{O}_{3}\right) . \text { Fabricante: } \\
\text { Essêncial. }\end{array}$ & 1183 & $0,0054 T^{2}-0,3460 T+6,1292$ \\
\hline Óleo mineral & $\begin{array}{l}\text { Óleo mineral técnico 75. } \\
\text { Fabricante: Fábrica de } \\
\text { vaselina da Bahia S.A. } \\
\text { (Favab) }\end{array}$ & 781 & $4,476 \times 10^{-5} T^{2}-0,0027 T+0,0612$ \\
\hline SAE40 & $\begin{array}{l}\text { Óleo para motor tipo } \\
\text { SAE40. Nome comer- } \\
\text { cial: Motex HD. Fabri- } \\
\text { cante: Texaco de Brasil } \\
\text { S.A. }\end{array}$ & & \\
\hline SAE90 & $\begin{array}{l}\text { Óleo para transmissão } \\
\text { hipóide. Nome comer- } \\
\text { cial: Lubrax TRM 5. } \\
\text { Fabricante: Petrobras. }\end{array}$ & 871 & $0,0026 T^{2}-0,1683 T+2,9258$ \\
\hline SAE140 & $\begin{array}{l}\text { Óleo para transmissão } \\
\text { hipóide. Nome comer- } \\
\text { cial: Lubrax TRM 5. } \\
\text { Fabricante: Petrobras. }\end{array}$ & 877 & $0,0056 T^{2}-0,3479 T+6,1980$ \\
\hline SAE250 & $\begin{array}{l}\text { Óleo para caixa de } \\
\text { engrenagem e redutor. } \\
\text { Nome comercial: } \\
\text { Transmichamp EP250. } \\
\text { Fabricante: Petrobras. }\end{array}$ & & \\
\hline
\end{tabular}

${ }^{1}$ Faixa válida de temperatura: $15-25^{\circ} \mathrm{C}$

Tabela 3.2: Propriedades físicas das amostras da mistura glicose de milho-água a $19,5 \pm 0,2^{\circ} \mathrm{C}$.

\begin{tabular}{|c|c|c|}
\hline$\xi$ & $\rho\left(\mathrm{kg} / \mathrm{m}^{3}\right)$ & $\eta(\mathrm{Pas})$ \\
\hline \hline 0,70 & 1348 & 0,048 \\
\hline 0,80 & 1398 & 0,15 \\
\hline 0,90 & 1448 & 1,12 \\
\hline 0,95 & 1473 & 4,93 \\
\hline 1,00 & 1498 & 24,9 \\
\hline
\end{tabular}

Densidade e viscosidade em função da fração de masa $(0,7 \leq \xi \leq 1,0)$ :

$$
\rho(\xi)=1498 \xi+998(1-\xi)
$$

$\log _{10} \eta(\xi)=8,76 \xi^{3}-1,25 \xi^{2}-7,99 \xi+1,88$ 
Tabela 3.3: Propriedades físicas do sólido usado na interface de medição.

\begin{tabular}{|c|c|c|}
\hline Material & $\rho\left(\mathrm{kg} / \mathrm{m}^{3}\right)$ & $c(T)(\mathrm{m} / \mathrm{s})$ \\
\hline \hline Acrílico & 1179 & $-2,4 T+1370$ \\
\hline
\end{tabular}

\subsection{Propriedades físicas do sólido usado na interface de medição}

O material sólido usado na interface de medição foi escolhido, principalmente, pela sua baixa impedância acústica que, como mostrado na seção 2.8, aumenta consideravelmente a sensibilidade na medição do coeficiente de reflexão. Foi usado acrílico. As propriedades físicas de interesse são mostradas na tabela 3.3. A densidade foi medida por pesagem de uma amostra de geometria conhecida. Para medir a velocidade de cisalhamento, foi usada a célula com transdutor de cisalhamento (CTC) para determinar o tempo de atraso de dois ecos sucessivos no material sólido da interface de medição. O algoritmo empregado foi o da transformada de Hilbert da correlação cruzada.

\subsection{Análise dos resultados experimentais}

A precisão da técnica de medição é afetada por muitos fatores: gradientes de temperatura nas linhas de retardo, atenuação das ondas, instabilidades na eletrônica, entre outros. Em vista disso, uma completa análise do efeito de cada fator sobre a medição final é necessária para uma implementação prática do método fora do âmbito do laboratório. Contudo, neste trabalho são estudadas as bases do método de uma maneira geral sem se aprofundar nos detalhes inerentes à aplicação prática do método. Portanto, os erros induzidos na medição são tratados de uma maneira global. Isso é feito, principalmente, comparando-se os valores medidos de viscosidade por ultrassom àqueles medidos com o viscosímetro rotacional à mesma temperatura. O desvio é calculado usando a seguinte equação:

$$
e=\frac{\left|\eta-\eta_{0}\right|}{\eta_{0}} \cdot 100 \%
$$

onde $\eta$ e $\eta_{0}$ são as viscosidades medidas por ultrassom e com o viscosímetro rotacional, respectivamente. No cálculo do desvio percentual $e$, a viscosidade medida com o viscosímetro rotacional serve como base para comparação dos resultados. Como dito na seção 3.3, os erros decorrentes da medição com o 
viscosímetro rotacional não são levados em conta. Os valores do desvio percentual são mostrados nos gráficos de resultados de viscosidade.

No caso de um líquido não Newtoniano, no qual a viscosidade é afetada pelo efeito elástico, é mais difícil a comparação dos resultados. No entanto, os resultados obtidos com os líquidos Newtonianos mostraram a precisão da técnica e permitem, até certa medida, extensão aos líquidos viscoelásticos. 


\section{Medição em regime newtoniano}

Na seção 3.2 foi apresentada a técnica que permite medir o coeficiente de reflexão, magnitude e fase, numa única frequência. Essa foi a técnica empregada em todos os trabalhos publicados até hoje na determinação da viscosidade dinâmica dos líquidos usando ondas de cisalhamento. Muitos trabalhos concluíram que o efeito viscoelástico devido à alta frequência do ensaio é a causa da discrepância entre as viscosidades medidas por ultrassom e usando o viscosímetro rotacional (COHENTENOUDJI et al., 1987). No entanto, alguns autores acreditam que mesmo para as medições realizadas nas frequências ultrassônicas, como as usadas neste trabalho $(1-3,5 \mathrm{MHz})$, muitos líquidos deveriam apresentar comportamento newtoniano (HARRISON; BARLOW, 1981; KULMYRZAEV; MCCLEMENTS, 2000).

Segundo Harrison e Barlow (HARRISON; BARLOW, 1981), pode-se estabelecer de uma maneira qualitativa se o líquido apresenta comportamento newtoniano a certa frequência usando o tempo de relaxação de Maxwell $\tau_{m}$. Para isso deve-se respeitar que $\tau_{m}<<\tau_{d}$, onde $\tau_{d}=1 / f$ é o tempo característico do processo de deformação e $f$ é a frequência do ensaio. Para estimar $\tau_{m}$ pode-se usar a seguinte relação empírica (KULMYRZAEV; MCCLEMENTS, 2000):

$$
\tau_{m}(\mathrm{em} \mathrm{ns})=\eta(\mathrm{em} \mathrm{Pas})
$$

Pode-se aplicar essa relação empírica somente a óleos de baixa viscosidade e líquidos com moléculas simples, tais como glicose ou glicerina. Nos óleos mais viscosos derivados do petróleo e resinas poliméricas, essa relação não é mais válida.

Como exemplo da aplicação da relação empírica (4.1), analisa-se o caso do óleo mineral. A partir das propriedade físicas mostradas na seção 3.3, a viscosidade dinâmica é $0,023 \mathrm{Pas}$ à temperatura do teste por ultrassom de $23,3^{\circ} \mathrm{C}$. Aplicando a equação (4.1), tem-se $\tau_{m}=0,023$ ns. Se a frequência do teste é $1 \mathrm{MHz}$, então 
(a)

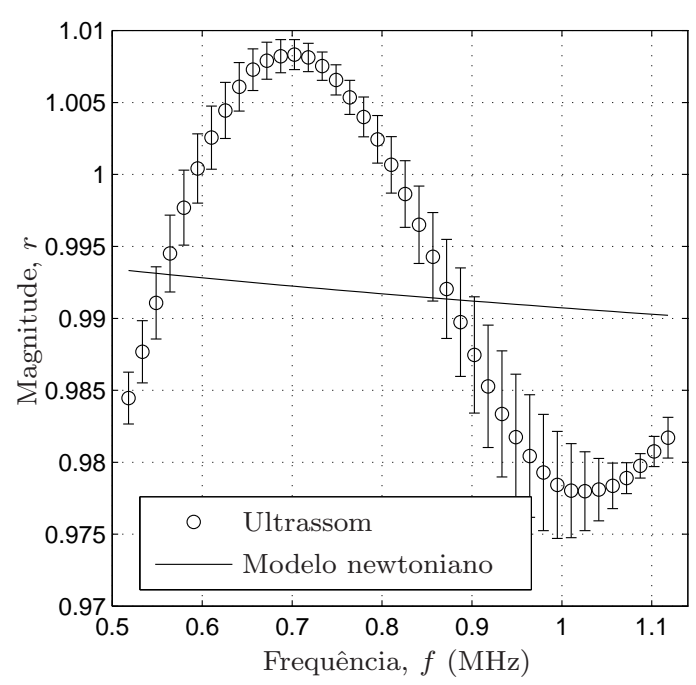

(b)

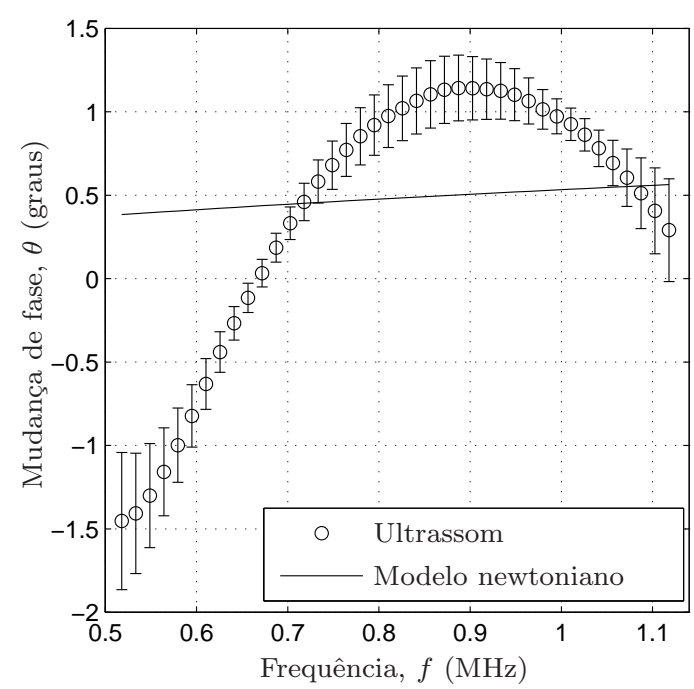

Figura 4.1: Magnitude (a) e mudança de fase (b) em função da frequência para óleo mineral a $23,3 \pm 0,3^{\circ} \mathrm{C}(\mathrm{CTC})$.

$\tau_{d} \approx 1 \mu \mathrm{s}$, ou seja, $\tau_{d}$ é aproximadamente quarenta mil vezes maior que $\tau_{m}$. Isso é suficiente para esperar comportamento newtoniano e, por conseguinte, a viscosidade medida por ultrassom deve ser a mesma viscosidade dinâmica.

Os resultados de magnitude e fase, para o óleo mineral, calculados usando a célula CTC a $1 \mathrm{MHz}$, e em uma banda de frequência de largura de $-3 \mathrm{~dB}$, são mostrados na figura 4.1. Os resultados são a média e o desvio padrão de quatro ensaios, os quais foram comparados aos valores esperados segundo o modelo de líquido newtoniano. Os valores de $r$ e $\theta$ obtidos por ultrassom são altamente dependentes da frequência, contrário aos valores fornecidos pelo modelo newtoniano que decrescem ligeiramente com a frequência e de uma maneira quase linear para um líquido dessa viscosidade. No entanto, os valores obtidos por ultrassom oscilam ao redor do valor esperado, sendo que, numa pequena variação de frequência, pode-se ter uma grande variação no coeficiente de reflexão e, por conseguinte, nas propriedades viscoelásticas. Assim, os valores obtidos numa única frequência são pouco úteis, mas a análise dos valores em conjunto numa banda de frequência apropriada pode levar a melhores resultados.

Kasolang e Dwyer-Joyce (KASOLANG; DWYER-JOYCE, 2008) também calcularam $r$ em função da frequência para um óleo de baixa viscosidade e usando um dispositivo similar à célula CTC. Os resultados obtidos foram similares aos 
mostrados na figura 4.1a, porem a variação na frequência foi menor que a obtida neste trabalho. No caso da fase, alguns autores tentaram medí-la usando excitação em banda larga com resultados modestos (SHAH; BALASUBRAMANIAM, 2000; KULMYRZAEV; MCCLEMENTS, 2000).

\subsection{Medição da magnitude}

Como mostrado na seção 2.6, a viscosidade em regime newtoniano pode ser obtida a partir somente da magnitude do coeficiente de reflexão. Isso é vantajoso pois a magnitude é uma grandeza relativamente estável e muito menos afetada pela temperatura que a fase. Contudo, os trabalhos apresentados por vários autores mostraram uma grande dificuldade na obtenção de resultados experimentais consistentes com a teoria (COHEN-TENOUDJI et al., 1987). A partir dos resultados mostrados no início do capítulo e visando melhorar a acurácia na medição da magnitude do coeficiente de reflexão, a técnica da banda de frequência apresentada na subseção 3.2.2 foi desenvolvida.

Para testar a técnica, medições com glicerina U.S.P em função da temperatura $\left(15-25^{\circ} \mathrm{C}\right)$ e a mistura de glicose de milho e água em função da concentração de glicose $(70-100 \%$ em peso) foram feitas a 1,0 MHz usando a célula CCM. As propriedades físicas dos líquidos testados foram apresentadas na seção 3.3. Os ensaios foram feitos de acordo ao procedimento apresentado na subseção 3.2.3.

Na figura 4.2 são mostrados os resultados da magnitude $r$ medidos por ultrassom em função da largura de banda, para valores de $\beta$ variando de 0 a 0,8 , para a glicerina a diferentes temperaturas. A temperatura de cada ensaio, assim como a precisão do banho termostático, é mostrada em cada gráfico. Os resultados são comparados aos valores de magnitude fornecidos pelo modelo newtoniano usando a viscosidade medida com o viscosímetro e as demais propriedades físicas conhecidas (ver seção 3.3).

Os valores de $r$ para $\beta=0$ ficam sempre muito acima dos valores esperados. À medida que $\beta$ aumenta, a magnitude diminui até um valor mínimo, que ocorre aproximadamente em $\beta=0,4$. Após esse valor mínimo, o desvio aumenta novamente. O comportamento é idêntico para todas as temperaturas, mas a localização do valor mínimo muda ligeiramente. Além disso, em alguns casos os desvios padrão ficam menores à medida que o desvio diminui. 

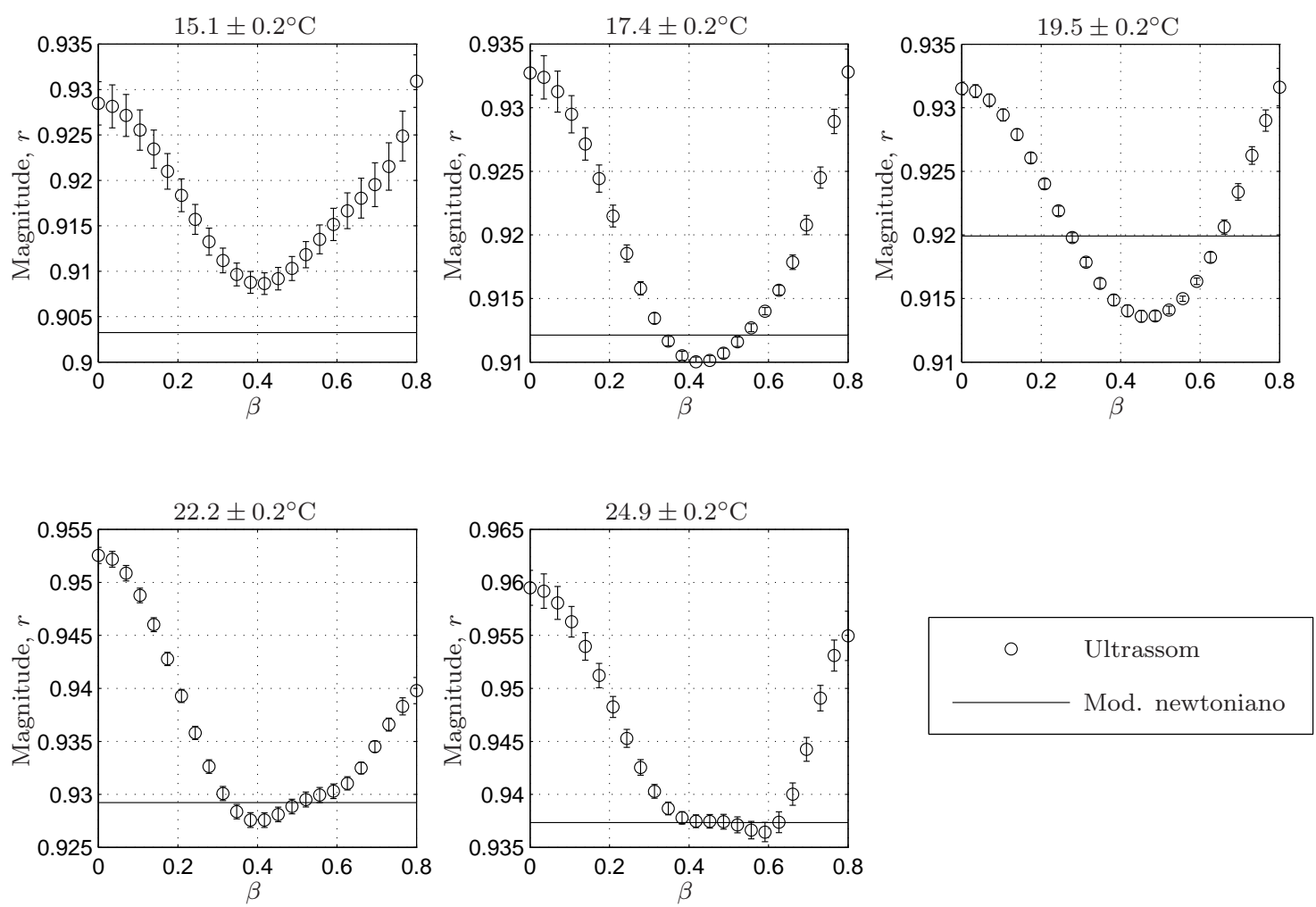

Figura 4.2: Magnitude do coeficiente de reflexão, em função da largura de banda (parâmetro $\beta$ ), para glicerina na faixa de temperatura entre 15 e $25^{\circ} \mathrm{C}$ (CCM)

Na figura 4.3 são mostrados os mesmos resultados da figura anterior para as amostras da mistura de glicose de milho e água. Os valores de $r$ para $\beta=0$ ficam também sempre muito acima dos valores esperados, inclusive é obtida uma magnitude maior que um na amostra de menor concentração (70\% em peso de glicose). O comportamento do desvio é igual ao mostrado na figura anterior.

Na figura 4.4 são plotados os resultados de viscosidade correspondentes às magnitudes, mostradas nas figuras 4.2 e 4.3, calculados na frequência central $(\beta=0)$ e na banda de frequência com menor desvio $(\beta=0,4)$, e comparados à viscosidade medida com o viscosímetro rotacional. O uso da banda de frequência resultou em valores mais precisos da viscosidade do que o da técnica da frequência central. O maior desvio porcentual passou de 96,8\%, no caso da frequência central, para $12,5 \%$, no caso da banda.

Os resultados da glicerina em função da temperatura, figura 4.4a, abrangem uma faixa de viscosidade entre 0,85 e 2,15 Pas e os resultados da mistura glicose- 

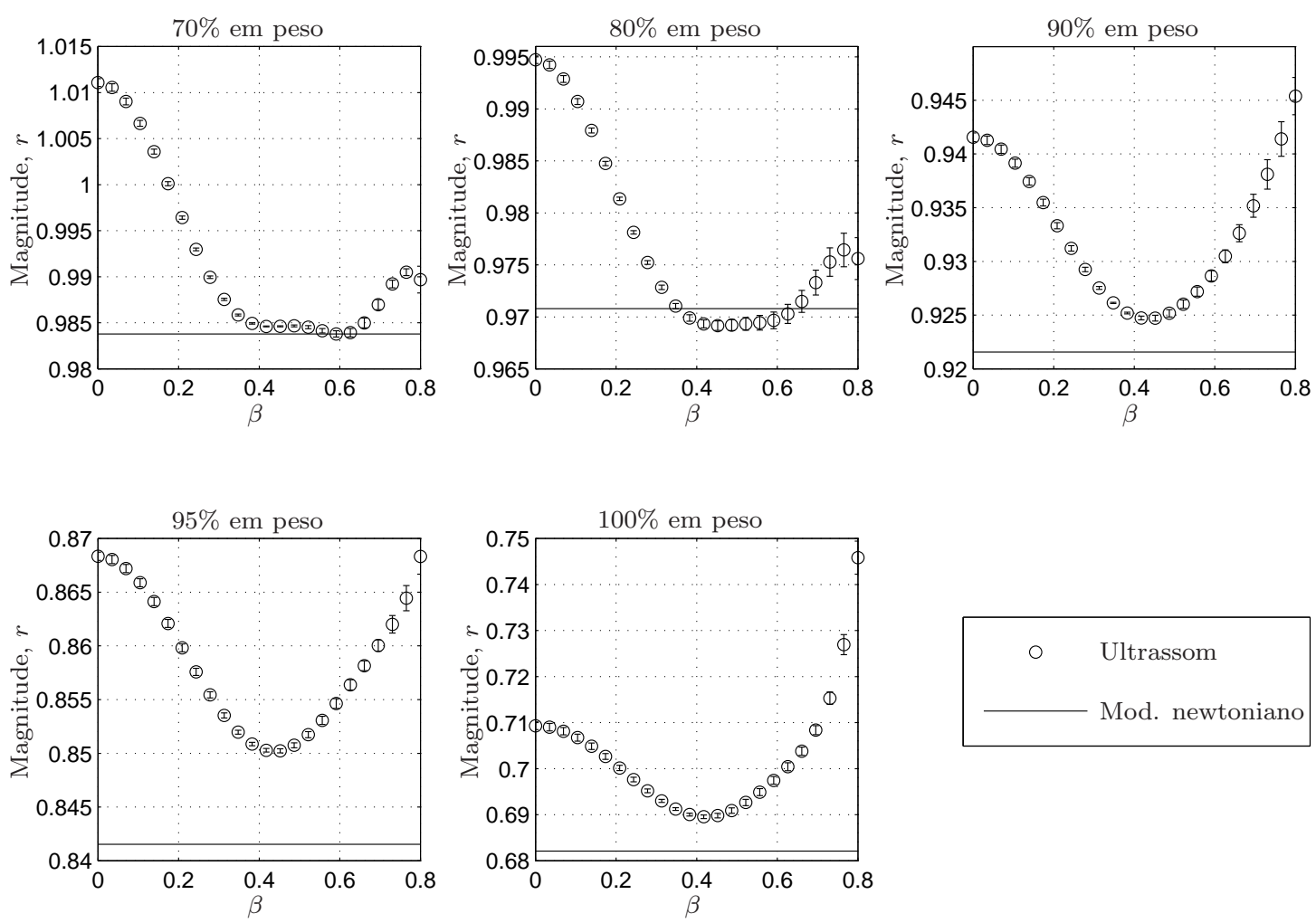

Figura 4.3: Magnitude do coeficiente de reflexão, em função da largura de banda (parâmetro $\beta$ ), para a mistura água-glicose de milho para diferentes concentrações de glicose (CCM).

água, figura 4.4b, abrangem uma faixa de viscosidade entre 0,048 e 24,9 Pa s. A medição da viscosidade com precisão menor do que 12,5\%, em todos os casos, mostra que a técnica da banda de frequência apresenta uma boa resolução e uma ampla faixa de medição.

Para mostrar melhor o efeito do cálculo na banda de frequência, a magnitude em função da frequência para todas as amostras da mistura de água-glicose de milho é mostrada na figura 4.5. Nota-se novamente como os valores medidos por ultrassom oscilam ao redor dos valores previstos pelo modelo newtoniano, inclusive a inclinação da curva aumenta nos casos das amostras mais viscosas. No gráfico também são mostrados os valores obtidos usando a técnica da banda de frequência para $\beta=0,4$. Esses valores são plotados na frequência central do pulso, sendo essa a frequência usada na equação (2.39) que calcula a viscosidade mostrada na figura $4.4 \mathrm{~b}$.

O comportamento físico dos valores de $r$ em função da frequência mostrado 
(a)

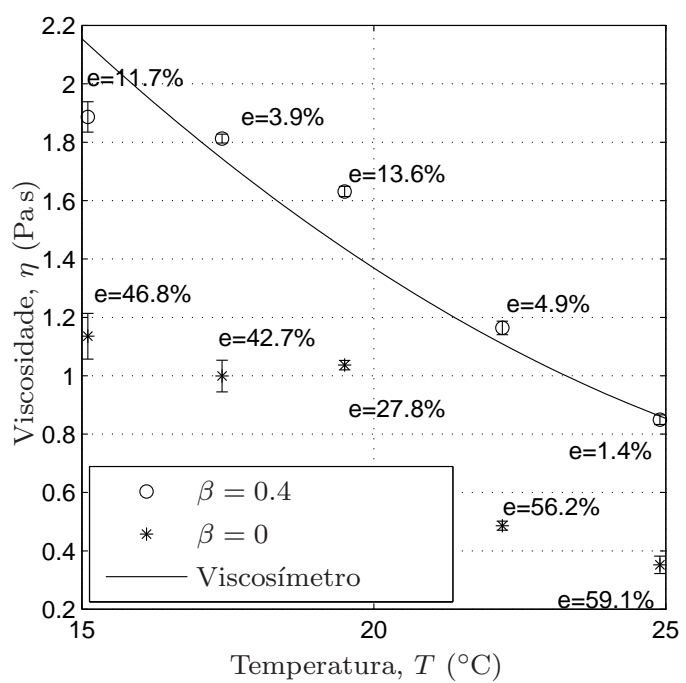

(b)

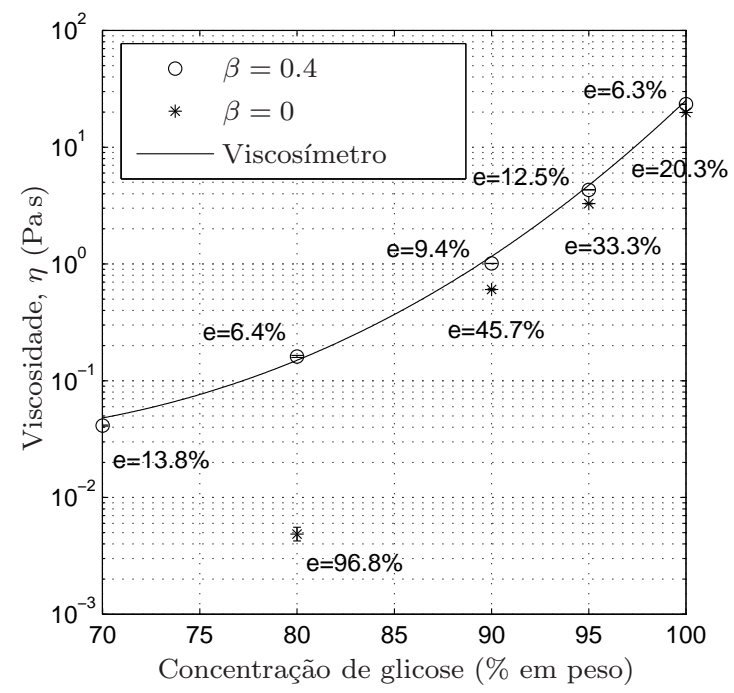

Figura 4.4: Viscosidade medida por ultrassom com glicerina (a) e a mistura água-glicose de milho (b) na frequência central do pulso $(\beta=0)$ e na banda de frequência com menor desvio $(\beta=0,4)$ comparada à viscosidade medida com o viscosímetro rotacional (CCM).

na figura 4.5, não é esperado. Na realidade, a teoria baseia-se na solução da equação de onda em regime harmônico, ou seja, supõe-se que a excitação seja feita numa única frequência. Entretanto, o teste experimental é realizado em modo pulso-eco, utilizando uma onda com espectro contínuo de frequências. Então, as características do ensaio estão longe de serem ideais. Por outro lado, no processo de reflexão na interface de medição sólido-líquido, as componentes dos sinais com frequências maiores transmitem mais energia ao líquido, causando distorção do pulso refletido.

Usando os resultados obtidos com a glicerina e a mistura água-glicose de milho, pode-se analisar a diferença nos valores fornecidos pelas equações (2.39) e (2.40). A figura 4.6 mostra os valores medidos de $r$ em função dos valores teóricos de $\left|Z_{L}\right| / Z_{S}$ calculados a partir das propriedades físicas conhecidas. Esses dados foram comparados aos valores teóricos fornecidos pelas equações (2.39) e (2.40). Para valores de $r$ maiores que 0,8 , os valores fornecidos por ambas as equações são praticamente o mesmo. Para valores de $r$ menores que 0,8 , a diferença é apreciável. O resultado para a amostra mais viscosa sugere que a equação (2.39) representa resultados experimentais de maneira mais fiel. 


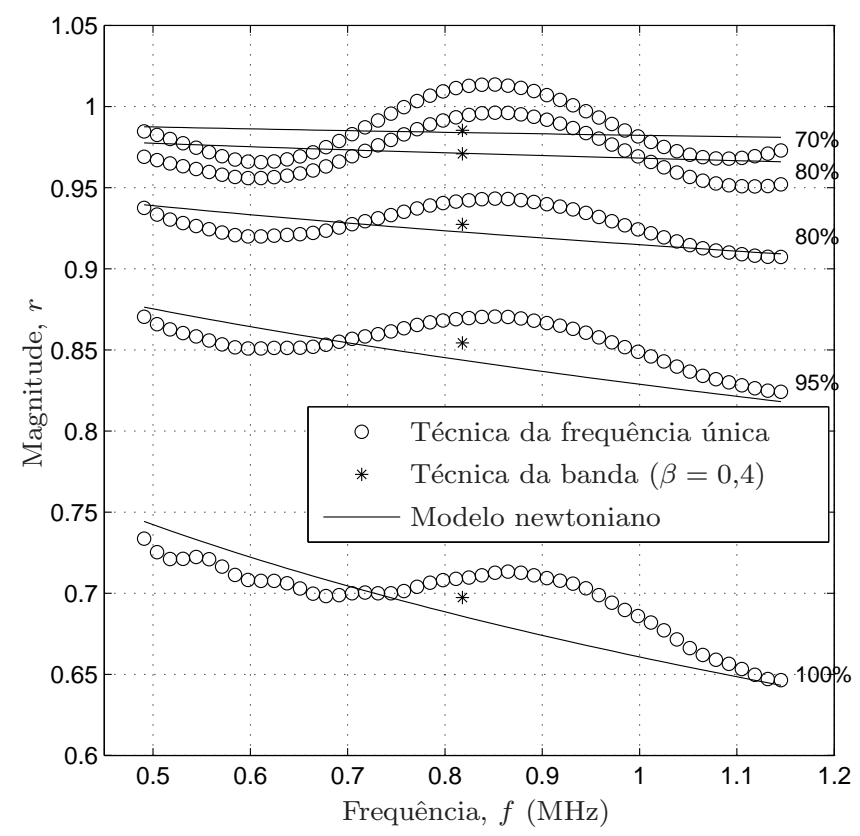

Figura 4.5: Magnitude do coeficiente de reflexão $r$ em função da frequência para as amostras da mistura água-glicose de milho e o efeito do cálculo na banda de frequência (CCM).

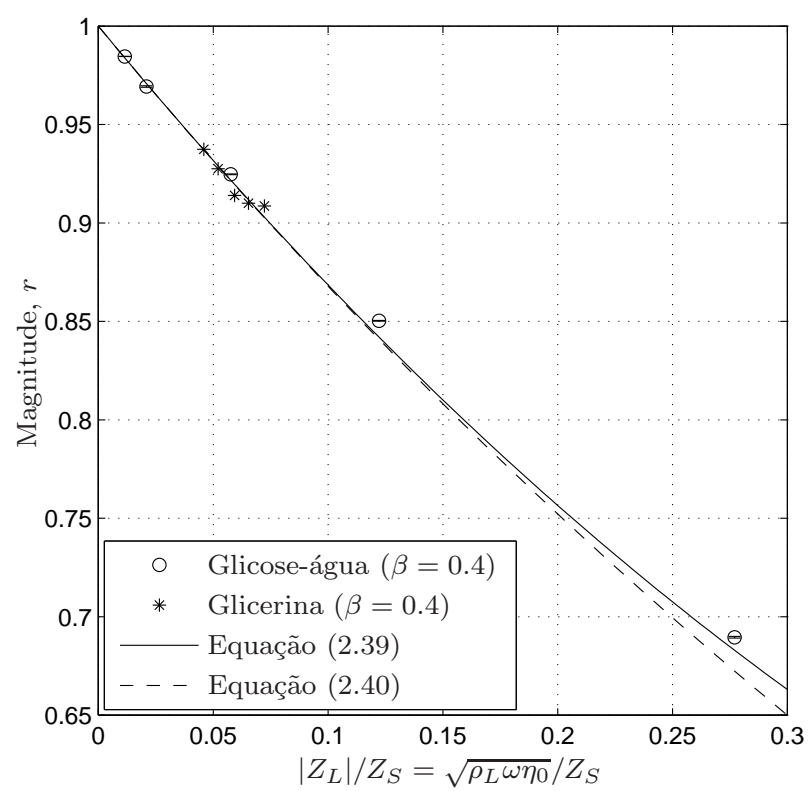

Figura 4.6: Valores medidos de $r$, para $\beta=0.4$, em função dos valores teóricos de $\left|Z_{L}\right| / Z_{S}$ dos resultados mostrados na figura 4.4 comparados com os valores teóricos fornecidos pelas equações (2.39) e (2.40). 
Os resultados das figuras 4.2, 4.3 e 4.4, obtidos com a técnica da banda de frequência, mostram o aumento na precisão da medição de $r$ e ,consequentemente, a redução no desvio porcentual entre as viscosidades medidas por ultrassom e as obtidas com o viscosímetro rotacional. Além disso, alguns resultados mostram que o desvio padrão também fica menor para os valores de $\beta$ que levam ao menor desvio porcentual.

Dando continuidade aos experimentos, quatro repetições do mesmo ensaio foram realizadas. Foram testados três líquidos com diferentes viscosidades e de diferentes naturezas: dois óleos derivados do petróleo, óleo mineral e óleo automotivo SAE40, e glicerina. As propriedades físicas desses líquidos são mostradas na seção 3.3. As viscosidades do óleo mineral, do óleo SAE40 e da glicerina, à temperatura na qual foram testados, são, respectivamente, 0,025, 0,36 e 1,37 Pas. Valores que abrangem três ordens de grandeza.

As figuras 4.7, 4.8 e 4.9 mostram os resultados obtidos no ensaio de repetibilidade com as amostras de óleo mineral, óleo automotivo SAE40 e glicerina, respectivamente. São mostrados os resultados da magnitude (a) e da viscosidade calculada pela equação (2.39) (b) em função da largura de banda $\beta$, sendo apresentados valores das médias e os desvios padrão das 4 repetições e suas comparações aos valores obtidos usando o viscosímetro rotacional. O desvio padrão é muito maior quando $r$ é calculado na frequência central $(\beta=0)$, que explica a grande incerteza na medição obtida por vários autores em trabalhos anteriores (COHEN-TENOUDJI et al., 1987)(FRANCO et al., 2008b). O óleo mineral, por exemplo, tem uma viscosidade de 0,025 Pas que é um valor muito baixo, quase no limite de precisão da técnica de medição na frequência de trabalho de $1 \mathrm{MHz}$. Além disso, apresenta-se, inclusive, um valor de $r$ maior que um, o que leva a uma viscosidade negativa sem significado físico.

Nas mesmas figuras, os desvios padrão de ambas as grandezas, $r$ e $\eta$, também têm um valor mínimo que coincide com o desvio porcentual mínimo para um $\beta$ de aproximadamente 0,4. A grande diferença na viscosidade dos líquidos usados contribui para uma comprovação experimental sistemática desses resultados. Alem disso, o fato de terem sido feitas quatro repetições com cada líquido mostra a repetibilidade dos resultados obtidos com a técnica da banda de frequência.

As medições anteriores foram feitas com a célula CCM, que utiliza a conversão de modo na interface água-alumínio, proporcionando ondas de cisalhamento mais 
(a)

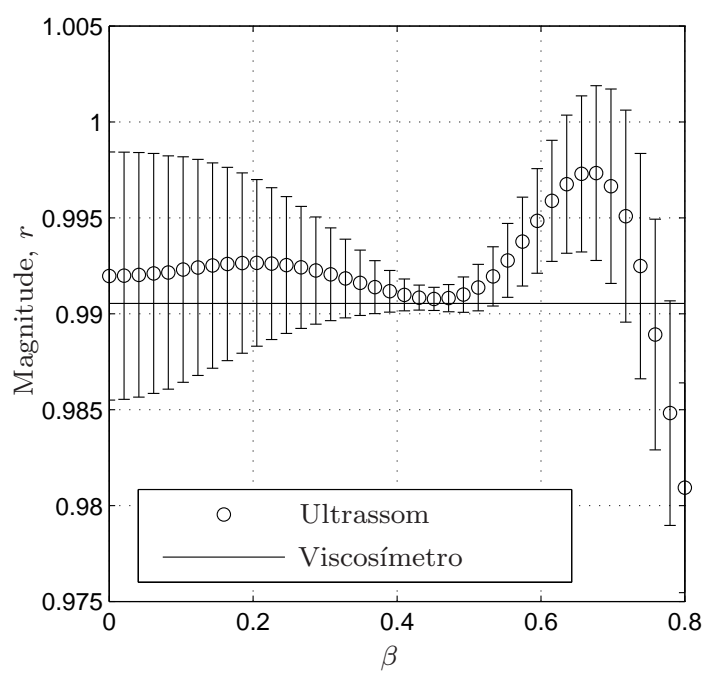

(b)

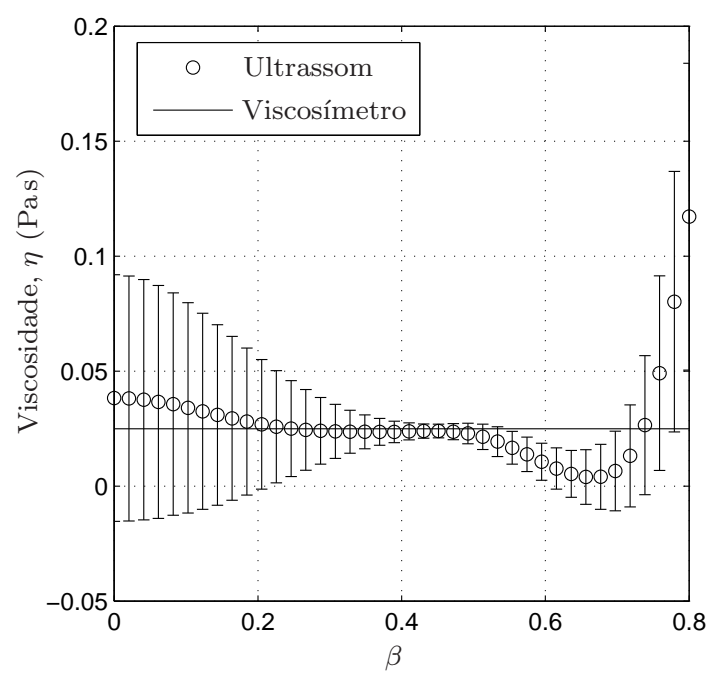

Figura 4.7: Magnitude do coeficiente de reflexão (a) e viscosidade (b) em função da largura de banda para óleo mineral a $18,2 \pm 0,2^{\circ} \mathrm{C}$. Resultado de quatro repetições a $1 \mathrm{MHz}$ usando a célula com conversão de modo (CCM).

(a)

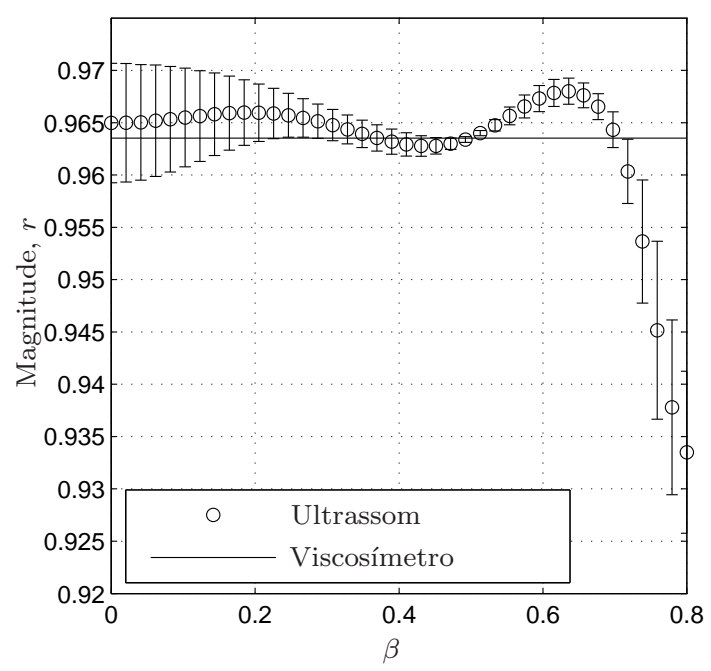

(b)

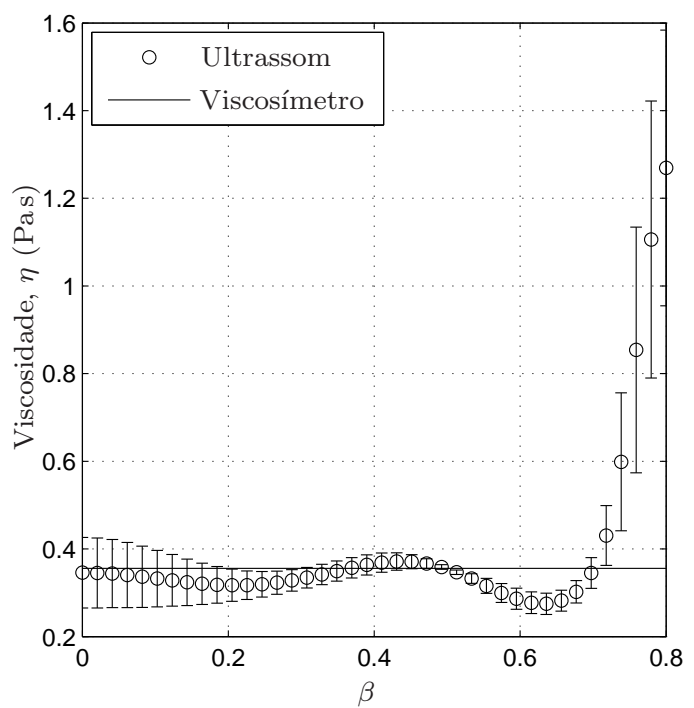

Figura 4.8: Magnitude do coeficiente de reflexão (a) e viscosidade (b) em função da largura de banda para óleo SAE40 a $20,1 \pm 0,2^{\circ} \mathrm{C}$, Resultado de quatro repetições a $1 \mathrm{MHz}$ usando a célula com conversão de modo (CCM). 
(a)

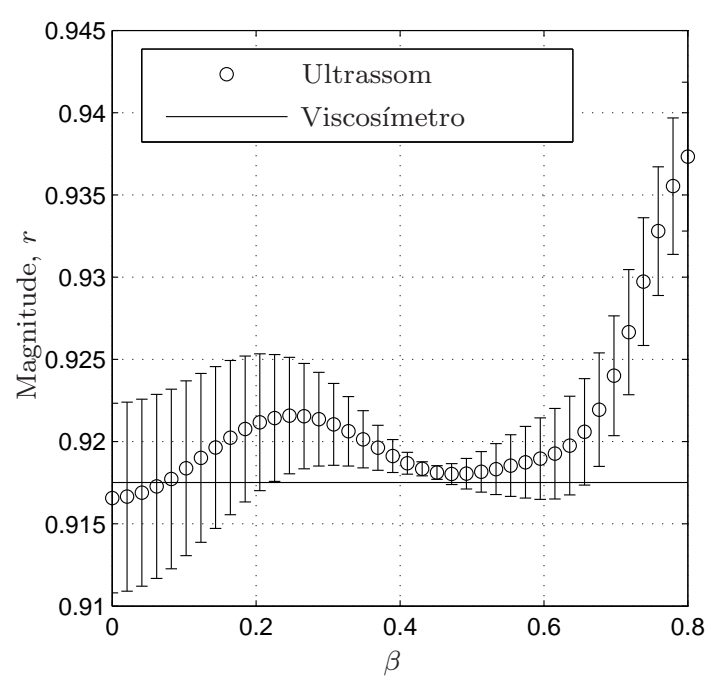

(b)

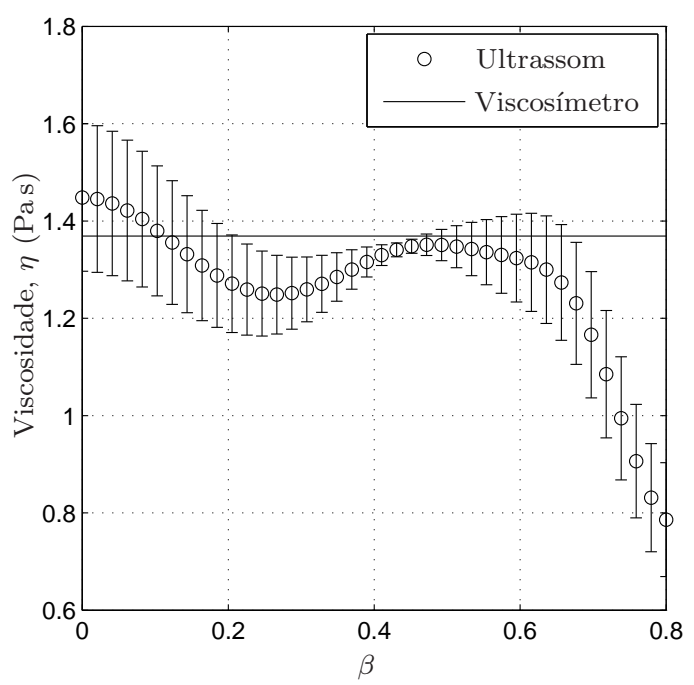

Figura 4.9: Magnitude do coeficiente de reflexão (a) e viscosidade (b) em função da largura de banda para glicerina U.S.P a $20,0 \pm 0,2^{\circ} \mathrm{C}$. Resultado de quatro repetições a $1 \mathrm{MHz}$ usando a célula com conversão de modo (CCM).

limpas. O projeto desse tipo de célula de medição é complicado, sendo o uso da linha de retardo de água pouco prático. É importante testar se a técnica da banda de frequência tem o mesmo efeito com outros tipos de célula de medição de mais fácil fabricação, especialmente o dispositivo que usa o transdutor de ondas de cisalhamento CTC. As vantagens e desvantagens das duas células de medição usadas foram listadas na seção 3.1.

Na figura 4.10 são mostrados os resultados da magnitude para óleo SAE40 e óleo mineral usando a célula com transdutor de cisalhamento a $1 \mathrm{MHz}$. O resultado é muito semelhante ao obtido com a célula com conversão de modo, o que permite concluir que a técnica da banda de frequência também funciona com a célula CTC.

\subsection{Medição da fase}

A medição da fase é muito difícil devido à sua grande dependência da temperatura, sendo que uma pequena mudança de temperatura, mesmo dentro da faixa de precisão da maioria dos banhos termostáticos disponíveis, pode gerar mudanças de fase da mesma ordem de grandeza da fase medida. No entanto, foi 
(a)

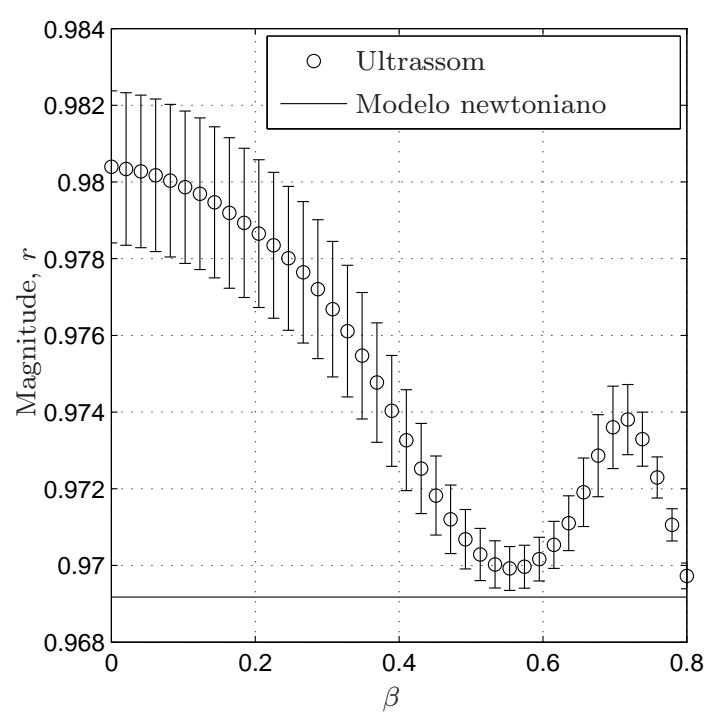

(b)

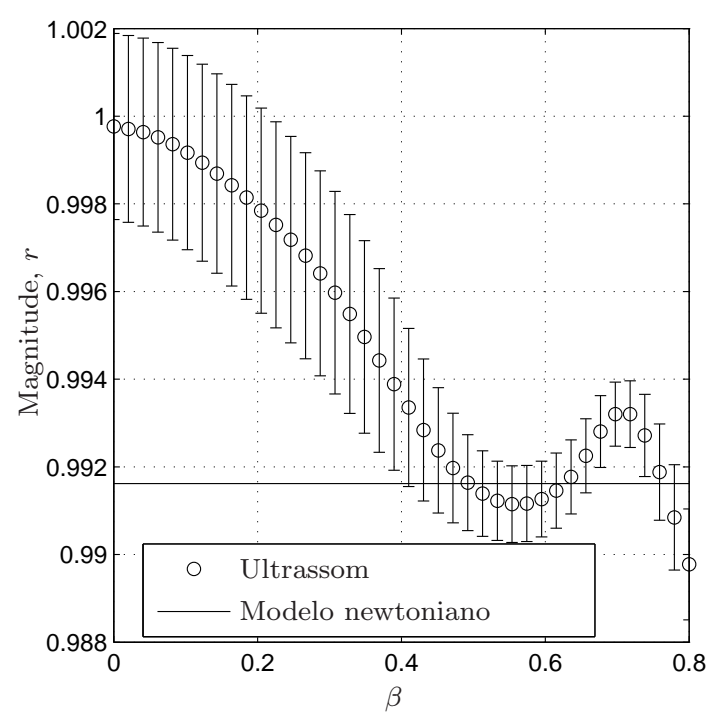

Figura 4.10: Magnitude do coeficiente de reflexão em função da largura de banda para (a) óleo automotivo SAE40 a $23,1 \pm 0,3^{\circ} \mathrm{C}$ e (b) óleo mineral a $23,3 \pm 0,3^{\circ} \mathrm{C}$. Resultado de quatro repetições a $1 \mathrm{MHz}$ usando a célula com transdutor de cisalhamento (CTC).

observado que essas pequenas mudanças de temperatura ocorrem num espaço de tempo relativamente longo, e esse fato pode ser reduzido se o teste for feito num tempo curto. Isso foi levado em conta ao se definir o procedimento do ensaio na seção 3.2.3. Contudo, a precisão na medição da fase sempre será muito menor que a precisão na medição da magnitude.

Na seção anterior foi mostrado que quando o líquido apresenta comportamento newtoniano, a medição somente da magnitude é suficiente para se determinar a viscosidade do líquido. No entanto, quando o efeito elástico é grande e o comportamento deixa de ser predominantemente newtoniano, a fase é necessária para se determinar a viscosidade e a elasticidade.

Na figura 4.1b, o valor da fase em função da frequência também oscila ao redor da curva esperada, segundo o modelo newtoniano. Isso sugere que, também no caso da fase, um esquema de cálculo numa banda apropriada pode levar a melhores resultados. Para testar essa ideia, foram usados óleo mineral e óleo SAE40 com a célula de medição com transdutor de cisalhamento (CTC) a 1 MHz, tendo sido realizados quatro repetições do ensaio.

Na tabela 4.1 são mostradas as fases medidas. Os resultados expostos na 
Tabela 4.1: Resultados obtidos nos testes de medição da mudança de fase usando a célula com transdutor de cisalhamento (CTC) a $1 \mathrm{MHz}$.

\begin{tabular}{|lc|c|c|}
\hline & & Óleo mineral & SAE40 \\
\hline \hline Temperatura do ensaio & $\left({ }^{\circ} \mathrm{C}\right)$ & $23,3 \pm 0,3$ & $23,1 \pm 0,3$ \\
\hline Fase esperada & $\left({ }^{\circ}\right)$ & 0,482 & 1,80 \\
\hline Fase medida $\left(f_{c}\right)$ & $\left(^{\circ}\right)$ & $1,0 \pm 0,19$ & $2,36 \pm 0,20$ \\
\hline Fase medida $(\beta=0,55)$ & $\left(^{\circ}\right)$ & $0,10 \pm 0,19$ & $1,18 \pm 0,1$ \\
\hline
\end{tabular}

seção 4.1 mostraram que esses líquidos apresentam comportamento newtoniano à frequência usada. As fases foram calculadas usando a técnica da frequência única, com a frequência central do pulso, e uma nova técnica que calcula a fase numa banda. A técnica simplesmente calcula a fase em função da frequência e o resultado final é o valor médio de todas as fases. A banda de frequência usada equivale ao valor de $\beta=0,55$ (figura 4.10). Pela natureza da fase, o cálculo na banda de frequência não pode ser feito para a fase da mesma maneira que para a magnitude.

A tabela 4.1 mostra que o cálculo na banda também não fornece melhores resultados. Os desvios entre os valores de fase esperados e medidos são muito grandes em ambos os casos. Consequentemente, a determinação experimental da fase continua sendo um problema sem solução com as técnicas usadas neste trabalho, pelo menos no caso dos líquidos newtonianos. No capítulo 5, a medição da fase vai ser abordada novamente no caso de líquidos não-newtonianos. 


\section{Medição em regime não-newtoniano e outras técnicas}

\subsection{Medição em regime não-newtoniano}

Nos resultados experimentais mostrados no capítulo 4 foi observado comportamento predominantemente newtoniano, como esperado para os líquidos testados de baixa viscosidade e com moléculas simples. Isso foi comprovado com os resultados obtidos usando a técnica da banda de frequência, visto que os desvios percentuais entre as viscosidades medidas por ultrassom e pelo viscosímetro rotacional foram pequenos. No caso dos óleos automotivos mais viscosos, o comportamento deve ser viscoelástico devido, principalmente, às grandes moléculas poliméricas que acrescentam os efeitos de relaxação. A consequência disso é, além do aumento da elasticidade, um decréscimo no valor da viscosidade medida, em função da viscosidade dinâmica do líquido e da frequência do ensaio.

\subsection{1 Óleos automotivos}

Os óleos automotivos SAE40, SAE90, SAE140 e SAE250, com propriedades físicas mostradas na seção 3.3, foram testados a $1 \mathrm{MHz}$ e temperatura ambiente usando o procedimento experimental da seção 3.2.3. As temperaturas dos ensaios foram $23,1 \pm 0,3,20,8 \pm 0,2,19,6 \pm 0,2$ e $21,8 \pm 0,2{ }^{\circ} \mathrm{C}$ para SAE40, SAE90, SAE140 e SAE250, respectivamente. Foram feitas quatro repetições com cada líquido. Entre esses óleos automotivos testados, o óleo SAE40 é o de menor viscosidade e foi testado no capítulo 4, mostrando comportamento newtoniano à frequência de $1 \mathrm{MHz}$. Já nos outros óleos a viscosidade aumenta progressivamente, sendo o SAE250 o mais viscoso com uma viscosidade 25 vezes maior, aproximadamente, do que a do SAE40. 
Na figura 5.1 são mostrados os resultados da magnitude $r$ e da mudança de fase $\theta$ em função da frequência para todos os óleos automotivos. A banda de frequência usada equivale ao valor de $\beta=0,55$, obtido a partir dos resultados mostrados na figura 4.10. Foram plotados a média e o desvio padrão dos quatro ensaios, assim como o valor obtido usando a técnica da banda de frequência e os valores esperados segundo o modelo de líquido newtoniano. No caso da fase, o resultado obtido por meio da técnica da banda de frequência é simplesmente o valor médio das variações de fase obtidas em todas as frequências.

Novamente os valores da magnitude em função da frequência oscilam ao redor da curva que representa o modelo newtoniano. No caso do óleo SAE40, o valor calculado pela técnica da banda de frequência coincide muito bem com o valor esperado pelo modelo newtoniano. Entretanto, à medida que a viscosidade dinâmica do líquido aumenta, o desvio entre esses valores aumenta. Isso significa que o comportamento vai se afastando do comportamento newtoniano. No caso da fase, também é mostrado o mesmo comportamento da oscilação observada para a magnitude. Os valores obtidos pela técnica da banda e a frequência central afastam-se dos valores esperados newtonianos, mas em maior proporção.

A figura 5.2 mostra a magnitude e a variação de fase obtidos com a técnica da banda de frequência em função do produto da densidade e da viscosidade dinâmica $\left(\rho \eta_{0}\right)$. A magnitude é mostrada na figura 5.2a, os valores medidos por ultrassom apresentam boa concordância com o modelo newtoniano para os óleos menos viscosos, SAE40 e SAE90, e o desvio aumenta progressivamente para os mais viscosos, SAE140 e SAE250. Os resultados da fase, apresentados na figura $5.2 \mathrm{~b}$, mostram que o desvio também aumenta progressivamente com a viscosidade dinâmica do líquido. No entanto, não foi obtida concordância numérica, mesmo no caso dos óleos menos viscosos.

Embora o desvio em relação ao modelo newtoniano aumenta progressivamente com a viscosidade, para ambas as grandezas, magnitude e fase, os comportamentos das curvas obtidas são similares ao modelo newtoniano. Os resultados mostram claramente que os efeitos de relaxação influenciam mais a fase do que a magnitude. Assim, a medição da magnitude é mais importante desde um ponto de vista tecnológico, dado que a determinação da fase apresenta muita incerteza. Além disso, a técnica da banda de frequência é a melhor opção disponível na estimativa da fase do coeficiente de reflexão. 

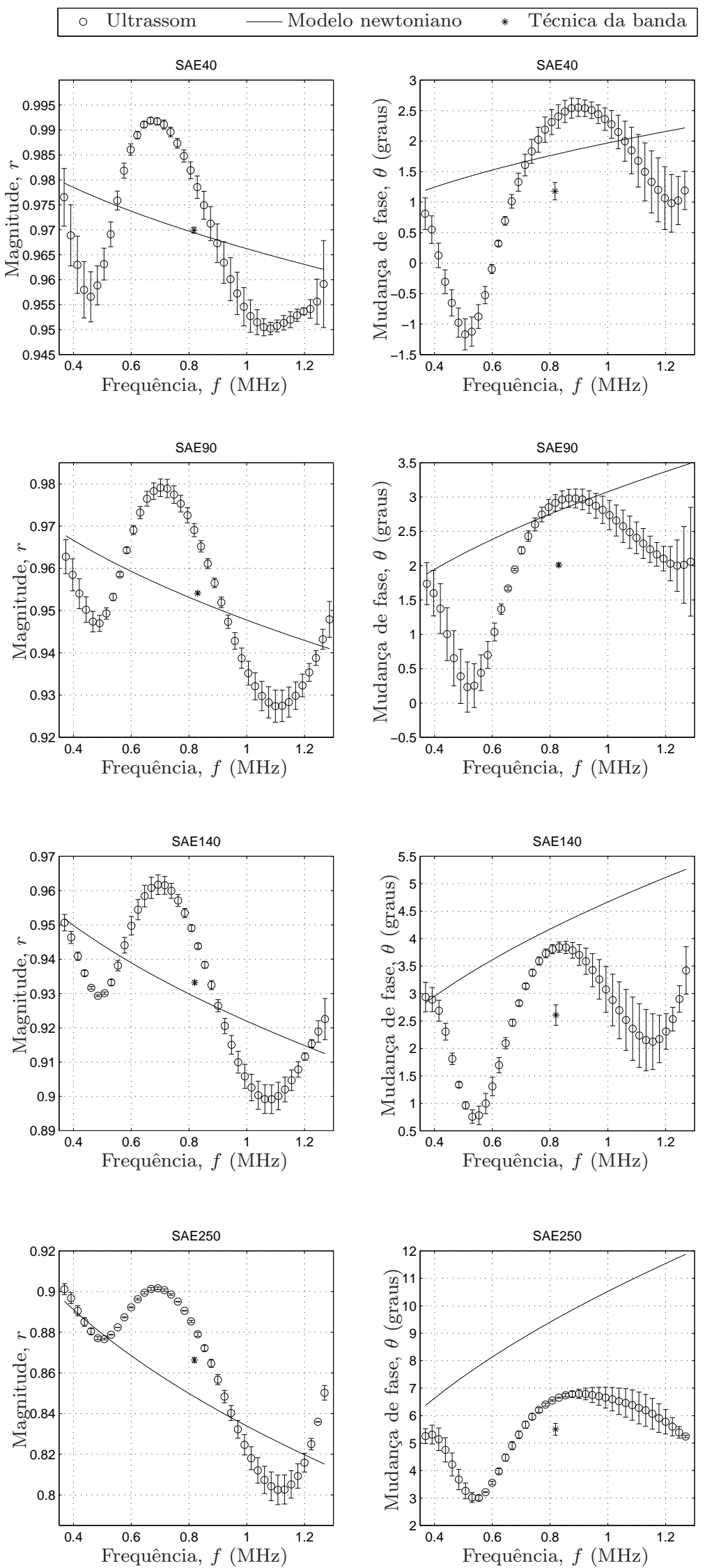

Figura 5.1: Magnitude e variação de fase do coeficiente de reflexão em função da frequência, para todos os óleo automotivos SAE40, SAE90, SAE140 e SAE250 na banda de frequência equivalente a $\beta=0,55$ (CTC). 
(a)

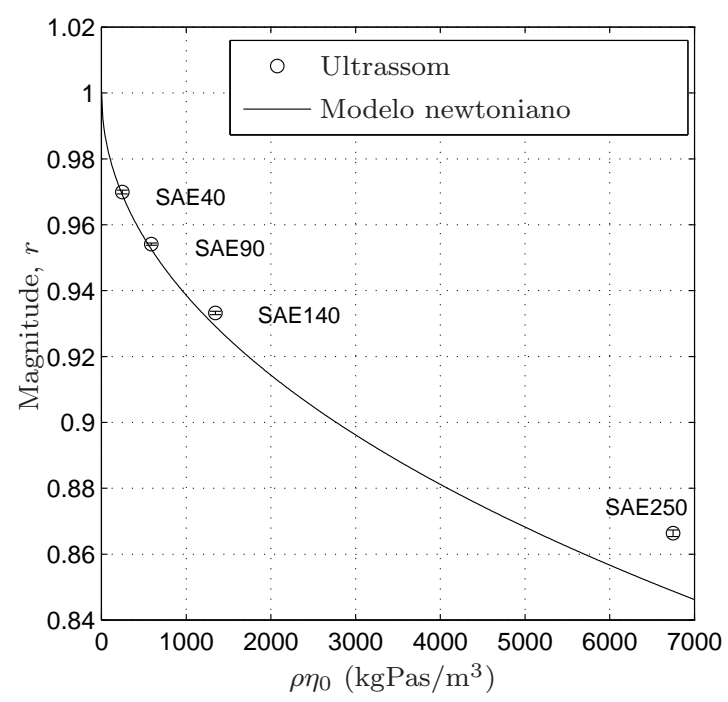

(b)

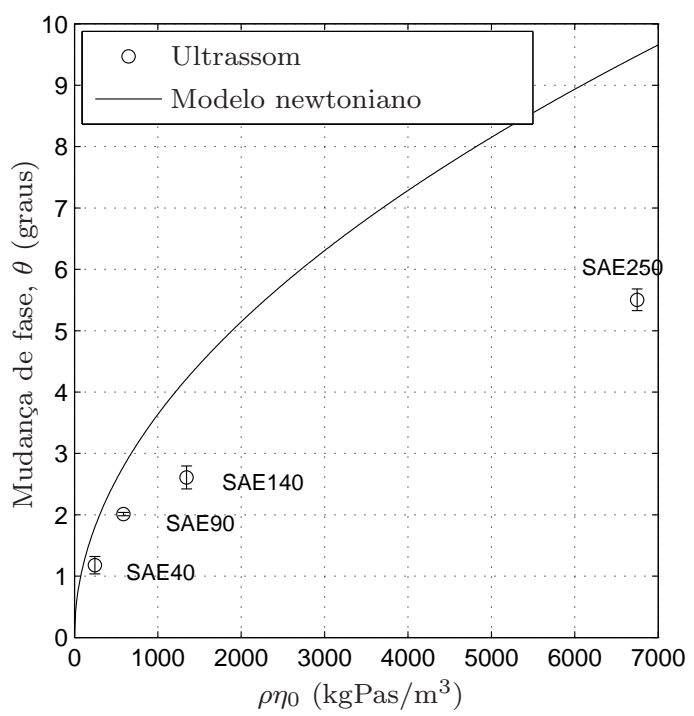

Figura 5.2: Magnitude (a) e variação de fase (b) em função do produto $\rho \eta_{0}$ para os óleos automotivos SAE40, SAE90, SAE140 e SAE250 (CTC).

Na figura 5.3a são mostrados os resultados da viscosidade $\eta$ obtidos por ultrassom em função da viscosidade dinâmica $\eta_{0}$ dos óleos automotivos. Os valores $\eta(r, \theta)$ calculados a partir da magnitude e fase empregando a equação (2.34) são indicados pelo símbolo "o", e os valores $\eta(r)$ calculados a partir somente da magnitude pela equação (2.39) são indicados por “*”. Os valores calculados somente com a magnitude apresentam menor desvio, porque a influência que o efeito viscoelástico tem sobre a fase não é levado em conta. Nessas condições, a viscosidade calculada usado ambas grandezas, magnitude e fase, é a viscosidade aparente do líquido na frequência do ensaio. Já a viscosidade obtida usando somente a magnitude é uma viscosidade com valor entre os valores da viscosidade aparente e da viscosidade dinâmica.

A elasticidade calculada a partir da magnitude e fase obtidos pela técnica da banda é plotada em função da viscosidade dinâmica, como mostra a figura 5.3b. A elasticidade cresce quase linearmente com a viscosidade dinâmica. Além disso, a reta ajustada passa muito perto da origem, como esperado. Resultados de elasticidade em líquidos a alta frequência são raros na literatura e todos os achados foram obtidos com técnicas similares às usadas neste trabalho. 
(a)

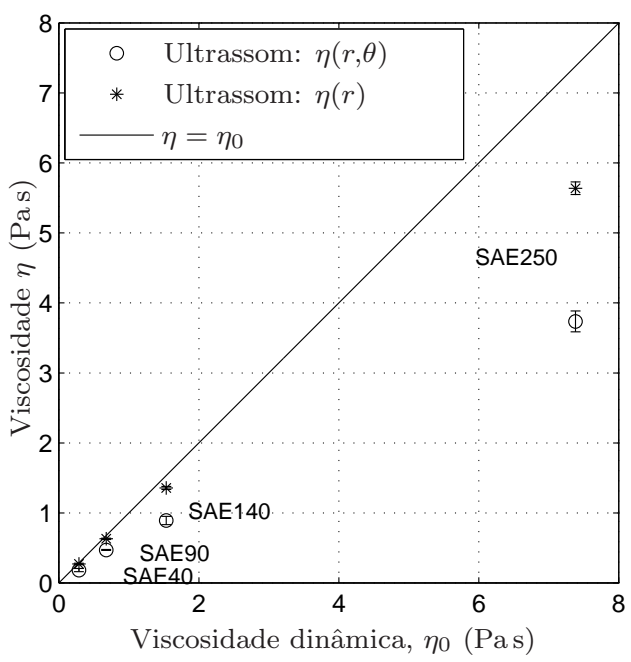

(b)

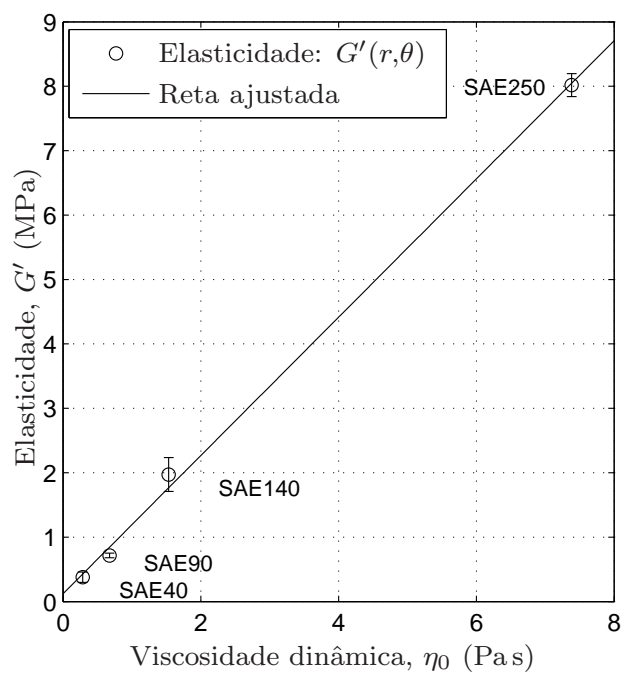

Figura 5.3: Viscosidade (a) e elasticidade (b) em função da viscosidade dinâmica do líquido para todos os óleos automotivos (CTC).

\subsection{Medição usando dispositivos calibrados}

Até agora, um modelo analítico que relaciona a viscosidade do líquido com o coeficiente de reflexão medido foi o método usado, ou seja, a medição foi realizada de maneira direta. No caso de regime newtoniano, os resultados obtidos apresentaram desvios pequenos em relação aos valores de viscosidade dinâmica, como mostrado nos capítulo 4. Quando o efeito elástico é grande o suficiente de modo a comprometer o modelo newtoniano, a medição direta leva a grandes desvios. Uma alternativa consiste na calibração de um dispositivo com dados conhecidos da viscosidade dinâmica, que pode ser aplicado para determinados líquidos ou grupo de líquidos.

Na figura 5.4 são mostradas as magnitudes medidas com os óleos automotivos e azeite de oliva usando a célula de medição com conversão de modo (CCM) com três transdutores de diferentes frequências: 1,0,2,25 e 3,5 $\mathrm{MHz}$. Os resultados foram plotados usando o complemento da magnitude medida $(1-r)$ no eixo $x$ e o produto da densidade pela viscosidade dinâmica $\left(\rho \eta_{0}\right)$ no eixo $y$. Os resultados experimentais foram ajustados usando o seguinte modelo:

$$
\rho \eta_{0}=\left[P_{1}(1-r)+P_{2}\right]^{1 / \epsilon},
$$

onde $P_{1}, P_{2}$ e $\epsilon$ são os parâmetros de ajuste do modelo. A equação (5.1) é 


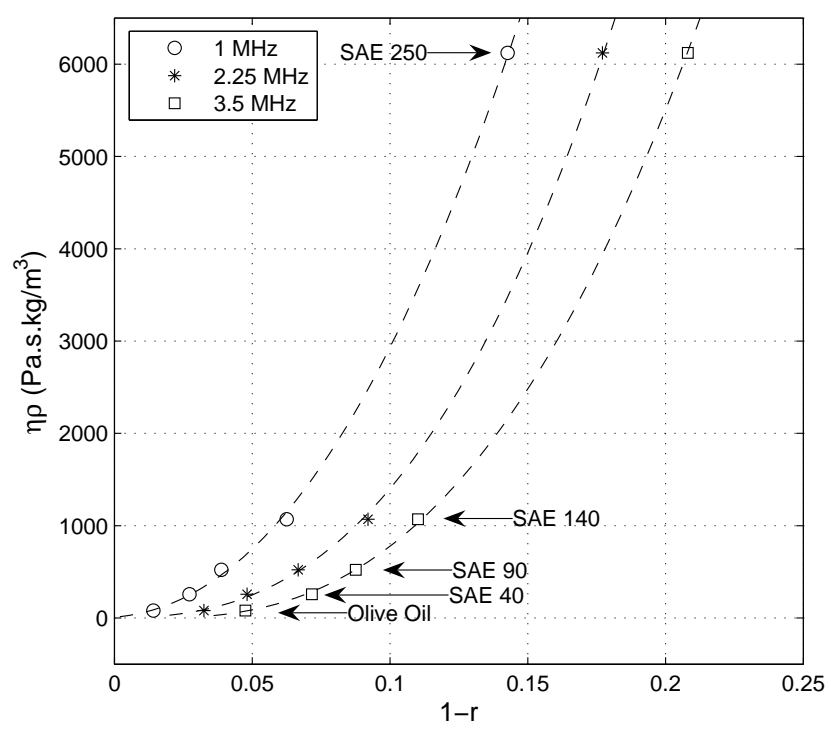

Figura 5.4: Valores esperados de $\rho \eta_{0}$ em função da magnitude medida para três frequências e curvas ajustadas (CCM).

basicamente a lei de potência. O parâmetro $P_{2}$ foi acrescentado visando melhorar o ajuste aos dados experimentais. As curvas ajustadas são mostradas com linhas tracejadas na figura e foram calculadas usando o algoritmo de regressão não linear de Matlab (NLINFIT). O ajuste inicial mostrou que o valor do parâmetro $\epsilon$ é aproximadamente 2,4 para as três frequências. Então, para obter as curvas mostradas na figura 5.4, o valor de $\epsilon=0,4$ foi fixado e novos ajustes foram feitos.

Os resultados mostram o aumento da sensibilidade com a frequência. Quando calculada a viscosidade desses líquidos a partir dos valores de $\rho \eta_{0}$ fornecidos pelas curvas ajustadas e da densidade conhecida, o desvio porcentual é menor que $11 \%$ para todos os casos. Os desvios maiores correspondem à frequência menor, sendo que a $3,5 \mathrm{MHz}$, os desvios porcentuais são menores que $3 \%$. Acredita-se que mudanças de temperatura fazem com que os resultados se movimentem ao longo da curva de calibração, no entanto, essa é uma questão importante que não foi comprovada neste trabalho.

Nesses resultados, a magnitude foi calculada usando o método da frequência central, devido à grande assimetria dos espectros de Fourier obtidos a 2,25 e 3,5 MHz. Nessas condições, um método diferente de análise dos sinais é necessário porque foi comprovado que o simples método da banda de frequência, apresentado na seção 3.2.2, não fornece bons resultados. 
Foi possível incluir o azeite de oliva nas curvas de ajuste dos óleos automotivos devido a sua baixa viscosidade. Nessas condições, o azeite de oliva apresenta comportamento newtoniano, tal como é o caso dos óleos automotivos menos viscosos. Um líquido newtoniano ligeiramente mais viscoso que o SAE40, não pode ser ajustado na mesma curva que os óleos automotivos, uma vez que o efeito viscoelástico causa discrepâncias na viscosidade medida por ultrassom, como mostrado na seção 5.1.1.

\subsection{Aplicações com emulsões água-óleo}

A detecção do conteúdo de água presente no óleo lubrificante é muito importante na manutenção de grandes máquinas rotativas, como turbinas de geração de eletricidade, bombas, motores de combustão interna, entre outros. O método da reflexão de ondas de cisalhamento já foi considerado para essa finalidade, mas nenhum sucesso foi obtido. Os resultados mostraram que devido à pequena penetração das ondas, elas não são afetadas pelas pequenas gotas de água na suspensão de óleo contaminado por água (JAKOBY; VELlEKOOP, 2004). No entanto, essa mesma característica da pequena penetração das ondas pode ser usada no caso contrário, ou seja, na monitoração de água contaminada por óleo. Ainda que tal monitoração seja de menor importância, aplicações em ciclos térmicos de potência e até na área ambiental podem ser de interesse. No caso dos ciclos térmicos, onde o fluido de trabalho é água, a eficiência geral é altamente dependente do bom desempenho dos trocadores de calor. Esse desempenho fica comprometido quando camadas de óleo ou sujeira depositam-se, reduzindo a transferência do calor.

No caso da emulsão de água contaminada com óleo, as gotas de óleo movimentam-se até atingir uma superfície ou ficar retidas em algum ponto de estagnação do fluido. Supondo que a interface sólido-líquido é a parede de um tanque ou canal de escoamento, praticamente uma reflexão completa é obtida à frequência de $1 \mathrm{MHz}$ quando água pura está em contato com a interface. Uma camada de óleo depositada na superfície, mesmo sendo sua espessura muito pequena, pode ser suficiente para provocar mudanças detectáveis na magnitude do coeficiente de reflexão.

Na figura 5.5 é mostrado o arranjo experimental usado. O sistema de excitação e recepção das ondas é igual ao usado anteriormente e mostrado na 


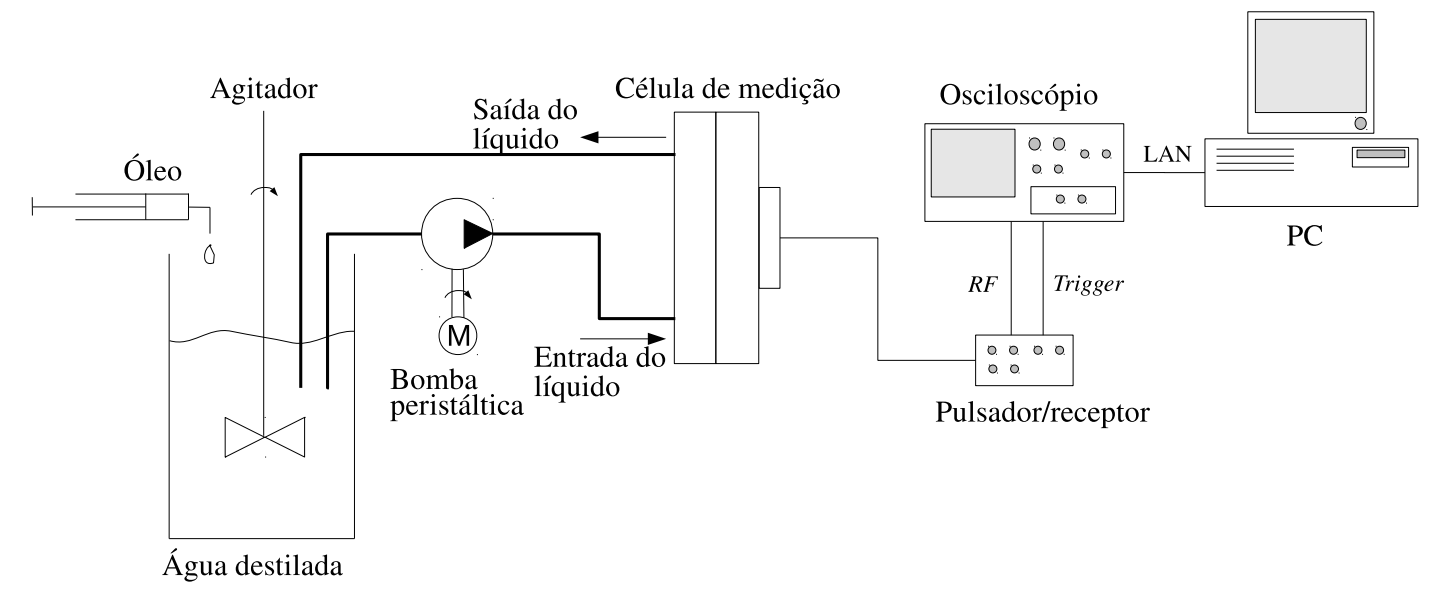

Figura 5.5: Arranjo experimental usado para testar o efeito das emulsões água-óleo na magnitude do coeficiente de reflexão (CTC).

figura 3.3. Há um sistema adicional usado para circular o líquido, constituído por uma bomba peristáltica, um béquer de $1000 \mathrm{ml}$, um agitador e mangueiras de silicone.

Dois testes preliminares para comprovar o efeito sobre a magnitude foram feitos. No primeiro, a um volume inicial de $1000 \mathrm{ml}$ de óleo SAE90 foram acrescentados $10 \mathrm{ml}(1 \%)$ de água destilada a cada 10 minutos. No segundo teste, foi feito o contrário: a um volume inicial de $1000 \mathrm{ml}$ de água destilada foram acrescentados $10 \mathrm{ml}$ de óleo SAE40 a cada 10 minutos. Em ambos os casos, no primeiro intervalo de tempo, as aquisições foram feitas sem acrescentar o contaminante, para se ter uma referência inicial. Na figura 5.6 são mostrados os resultados, obtidos usando a técnica da frequência central com a célula de medição com transdutor de cisalhamento (CTC). A mudança na magnitude é considerável no caso da água contaminada por óleo, e praticamente nula no caso contrário. Os teste foram feitos a temperatura ambiente, 20,0 e $20,3{ }^{\circ} \mathrm{C}$, respectivamente. Porém, no caso do óleo contaminado por água, um incremento de quase $5{ }^{\circ} \mathrm{C}$, devido ao atrito interno do óleo no processo de bombeamento, foi obtido no transcurso do ensaio. Esse incremento foi muito menor $\left({ }^{\circ} \mathrm{C}\right)$ no caso da água contaminada por óleo. O comportamento decrescente observado em ambos os casos pode ser explicado pelas mudanças de temperatura durante o ensaio e pelas instabilidades inerentes ao cálculo de $r$ usando o método da frequência central.

Os resultados obtidos no teste preliminar foram usados para projetar um novo ensaio em condições mais controladas. No novo ensaio foram acrescentados $5 \mathrm{ml}$ $(0,5 \%)$ de óleo SAE90 a cada meia hora. Além disso, a célula foi disposta com a 


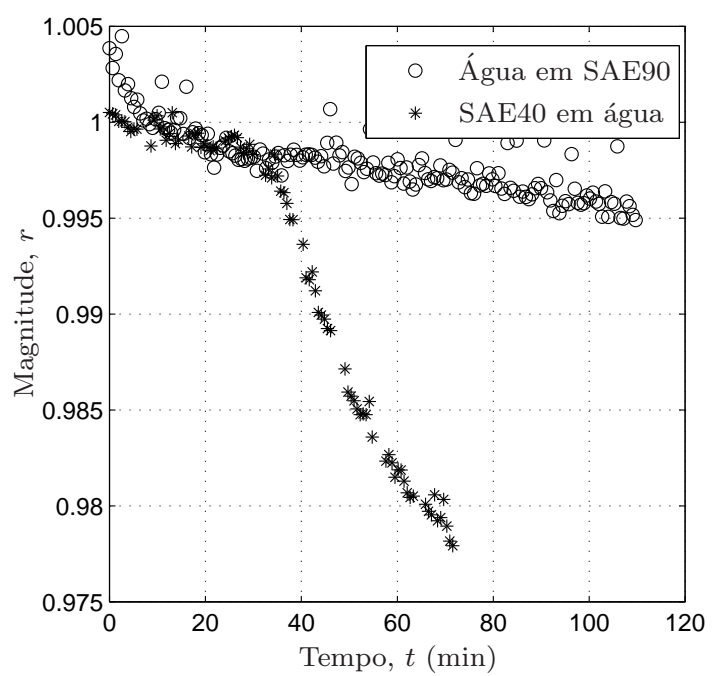

Figura 5.6: Magnitude medida em função do tempo e aquisição nos casos de óleo SAE90 contaminado por água e água contaminada por SAE40 (CTC).

interface de medição na posição horizontal, sendo que a entrada e saída do líquido ocorria na direção vertical. Isso foi feito para aumentar a sensibilidade, já que a menor densidade do óleo que faz com que ele flutue, facilitando sua aderência à interface. Como a magnitude varia de acordo com a quantidade de gotas de óleo que vão se acumulando na interface de medição, fatores como a posição da célula e as velocidades de circulação do fluido e do agitador têm grande influência no resultado. O cálculo da magnitude foi feito usando ambas as técnicas estudadas neste trabalho. A célula de medição (CTC) foi mantida num banho para reduzir gradientes de temperatura.

Na figura 5.7 são mostrados os resultados obtidos no segundo ensaio. A temperatura medida no inicio do teste foi $22,6^{\circ} \mathrm{C}$ e no final $23,5^{\circ} \mathrm{C}$. Os resultados usando as duas técnicas para calcular a magnitude foram comparadas ao valor de magnitude esperado para SAE90 puro à temperatura média do teste. Pode-se ver uma mudança quase instantânea na magnitude quando os primeiros $5 \mathrm{ml}$ de óleos foram adicionados.

Os resultados sugerem que o método é apropriado para determinar simplesmente se certo umbral de contaminação foi superado. A determinação da quantidade de óleo contaminante é muito difícil, sendo mais provável a estimativa da sua viscosidade. Os resultados obtidos com a técnica da banda apresentam menor variação no tempo, sendo que o valor final estabilizou-se em, 


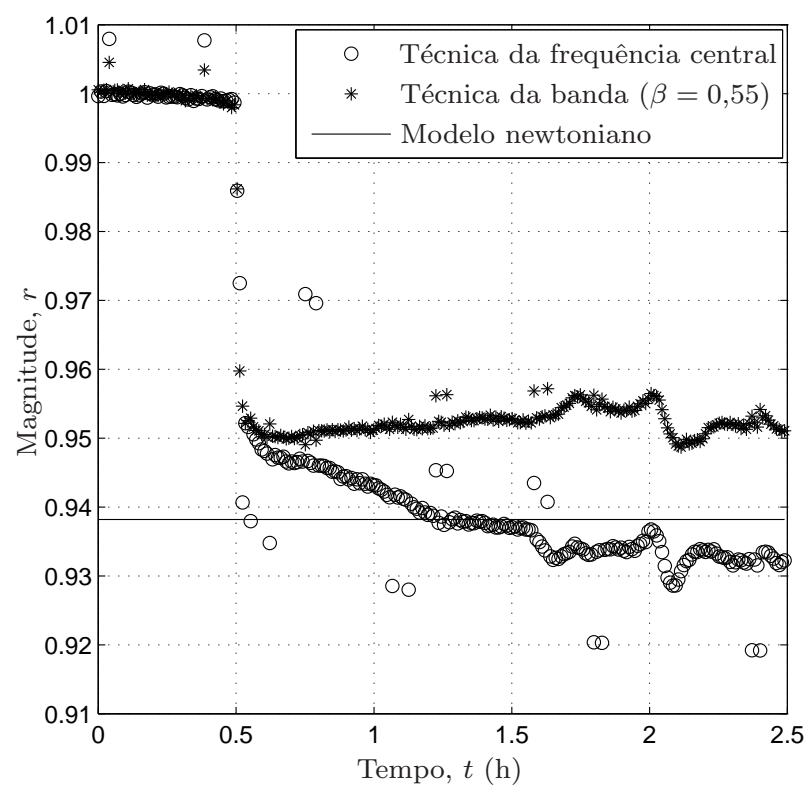

Figura 5.7: Magnitude do coeficiente de reflexão medida em função do tempo de aquisição no ensaio feito para detectar a contaminação da água por óleo (CTC).

aproximadamente, $r=0,95$. No caso da frequência central, o valor de magnitude continuou decrescendo até o final do ensaio.

Os ensaios realizados neste trabalho foram feitos à temperatura ambiente. Assim, a realização de testes a alta temperatura fica fora do alcance deste trabalho. A literatura relata que medições a alta temperatura do coeficiente de reflexão, para a monitoração da cura de polímeros (COHEN-TENOUDJI et al., 1987) e materiais fundidos até $1500^{\circ} \mathrm{C}$ (BALASUBRAMANIAM et al., 1999), foram feitas usando linhas de retardo longas fabricadas de materiais metálicos, como alumínio e cobre, e cerâmicos. Provavelmente, a técnica da banda de frequência possa ser usada nessa aplicação. 


\section{Conclusões e trabalhos futuros}

\subsection{Conclusões}

O tema da medição de viscosidade por ultrassom continua sendo de interesse na comunidade científica devido, principalmente, à possibilidade de realizar medições em tempo real, como requerido na indústria moderna altamente automatizada. Na literatura foram encontradas aplicações na indústria de alimentos, petroquímica e, mais recentemente, na engenharia civil, na monitoração da cura de concreto.

Neste trabalho, uma revisão bibliográfica completa do tema apresenta o estado da arte. Os trabalhos publicados mostram que apesar do método ser amplamente estudado, os resultados obtidos até agora foram pouco satisfatórios, discordando da teoria.

Embora a teoria envolvida no método de medição é relativamente simples, os resultados experimentais obtidos diferem consideravelmente. Entre as possíveis causas dessa discrepância estão a excitação em banda larga e a distorção do pulso refletido pela interface sólido-líquido. A excitação em banda larga é representada por um sinal com um espectro contínuo de frequências, enquanto a teoria considera, em condições ideais, excitação harmônica. Além disso, como a transferência de energia ao líquido no processo de reflexão na interface sólidolíquido é maior para frequências altas, o pulso fica distorcido, comprometendo sua comparação com a reflexão no caso sólido-ar.

A equação empregada por vários autores para calcular a viscosidade do líquido a partir da magnitude do coeficiente de reflexão é deduzida usando uma simplificação que supõe valores de fase pequenos. Neste trabalho foi mostrado que essa simplificação é desnecessária e uma nova equação mais apropriada foi 
apresentada. Além disso, foi mostrado que a nova equação (2.39) apresenta melhor concordância com os resultados experimentais.

As duas células de medição desenvolvidas neste trabalho (CCM e CTC) mostraram-se precisas e seus resultados repetitivos. Ambos os enfoques usados apresentam vantagens e desvantagens. A célula com conversão de modo permite realizar testes numa faixa de frequência maior, mas a célula com transdutor de cisalhamento é mais robusta e de projeto simples, sendo mais apropriada para aplicações fora do ambiente de laboratório. Contudo, testes com diferentes materiais e métodos de usinagem mais precisos serão necessários no futuro para otimizar o desempenho.

Os métodos experimentais usados neste trabalho mostraram ser apropriados na determinação do coeficiente de reflexão. A técnica da normalização com respeito ao sinal refletido pela interface alumínio-acrílico, de vital importância na aplicação do método, tinha sido usada pelo autor no seu trabalho de mestrado e foi aplicada aqui satisfatoriamente mostrando o sucesso desse enfoque.

Ao contrário do comportamento esperado, as magnitudes medidas apresentaram uma grande dependência da frequência. Foi observado como as curvas de magnitude em função da frequência oscilam ao redor dos valores esperados segundo o modelo newtoniano, levando a grandes erros no cálculo de $r$ numa frequência única. Ensaios com vários líquidos de diferentes tipos, como óleos automotivos e produtos alimentícios, foram realizados sempre à frequência de $1 \mathrm{MHz}$. Essa frequência foi escolhida a partir da experiência do autor no seu trabalho de mestrado.

Uma nova técnica que calcula a magnitude numa faixa de frequência foi desenvolvida neste trabalho. A técnica da banda de frequência mostrou-se bem sucedida na medição da viscosidade dinâmica de líquidos. Desvios porcentuais menores que $12,5 \%$, para vários líquidos testados numa faixa de viscosidade entre 0,023 e 24 Pas, mostram a precisão e a ampla faixa útil quando usada a técnica da banda. Esses resultados são inéditos na literatura.

A possibilidade do método ser aplicado para medições em tempo real o torna de grande interesse na área de automação industrial. O método da banda de frequência faz com que as medições de viscosidade fiquem mais perto da realidade, ou seja, da viscosidade dinâmica do líquido.

Embora a medição da fase seja de menor importância e maior dificuldade 
que a medição da magnitude, ela é necessária para medir a viscosidade e a elasticidade de líquidos quando o seu comportamento encontra-se longe de ser newtoniano. A aplicação de uma técnica de banda de frequência, similar à aplicada no caso da magnitude, permite estimar a fase. Contudo, a natureza da fase e sua grande dependência da temperatura fazem com que a exatidão dos resultados seja pequena.

Outra contribuição importante deste trabalho consiste na comprovação experimental da teoria. Outros autores que até agora usaram o método não conseguiram resultados experimentais satisfatórios. Os grandes desvios e pouca repetibilidade foram explicados por efeitos viscoelásticos, mesmo com líquidos que teoricamente deveriam ser newtonianos. A análise da medição do coeficiente de reflexão em função da frequência explica esses resultados e a técnica da banda de frequência leva a novos resultados coerentes com a teoria.

Os resultados mostram que a medição do coeficiente de reflexão e, por conseguinte, as propriedades viscoelásticas do líquido, simplesmente não pode ser medida em função da frequência usando o método de excitação em banda larga deste trabalho. No máximo, pode-se estimar um valor médio numa banda de frequência apropriada. Essa banda de frequência é determinada experimentalmente e depende principalmente da largura de banda do pulso gerado pelo transdutor.

Os óleos automotivos mostraram comportamento quase newtoniano no caso dos menos viscosos, e comportamento viscoelástico no caso dos mais viscosos. O comportamento viscoelástico é reconhecido pelo aumento do desvio porcentual com o aumento da viscosidade dinâmica do líquido ou da frequência do ensaio. A extensão da técnica da banda de frequência a líquidos em regime não-newtoniano perece melhorar os resultados obtidos. No entanto, a falta de uma base de comparação não permite testar a veracidade desses resultados.

A magnitude e a fase medidas com os óleos automotivos mostraram que os efeitos de relaxação influenciam em maior medida a fase. Esse resultado é promissor porque é a medição da magnitude que tem maior potencial para aplicações industriais.

A medição da viscosidade de líquidos usando curvas de calibração é um enfoque prático que pode ser de interesse na indústria. A vantagem principal consiste na inclusão dos efeitos de relaxação na curva de calibração, possibilitando 
o uso de frequências de trabalho maiores que melhoram consideravelmente a sensibilidade. Os resultados preliminares mostram que a magnitude medida, em função do produto da densidade pela viscosidade dinâmica, geram uma curva suave que pode ser facilmente ajustada com uma função simples do tipo exponencial. No entanto, ainda é necessário estudar o efeito da temperatura sobre a calibração e a aplicação do método da banda de frequência.

A monitoração da contaminação da água por substâncias oleosas é uma aplicação interessante do método de medição e que pode ser de utilidade na indústria. A monitoração pode ser feita em tanques ou tubulações, onde a superfície plana da interface de medição possa ser inserida como parte da parede, ou num caminho secundário, como foi o caso neste trabalho. Os resultados mostraram que determinar a quantidade do óleo contaminante é difícil, mas a detecção de um umbral de contaminação é muito eficiente.

Um fato importante nos ensaios realizados com a emulsão água-óleo é que as medições foram feitas com líquido em movimento.

\subsection{Trabalhos futuros}

Como expressado por alguns pesquisadores, o método ainda encontra-se limitado ao ambiente de laboratório e a implementação de aplicações práticas parece distante. Essas aplicações práticas dependem muito do desenvolvimento de novos dispositivos de medição, de materiais com melhores características e de técnicas experimentais que permitam compensar os erros induzidos pelo fatores mencionados ao longo do texto. Em vista disso, o autor propõe as seguintes atividades futuras:

- Testar novos materiais sólidos que substituam o acrílico na interface sólidolíquido, de modo a cumprir os requisitos de baixa impedância acústica e, ao mesmo tempo, baixa atenuação. Uma opção a considerar é o Rexolite.

- Estudar melhor a técnica de calibração proposta na seção 5.2. Essa técnica tem a vantagem de permitir o uso de uma frequência de trabalho maior, o que se traduz em maior sensibilidade e dispositivos de medição menores.

- Aplicar as técnicas experimentais desenvolvidas às células de medição com incidência oblíqua. 
- Testar a viabilidade de usar conversão de modo dentro do mesmo sólido (onda de cisalhamento refletida pela interface sólido-ar) em conjunto com as técnicas desenvolvidas neste trabalho. 


\section{Referências}

AKKAYA, Y.; VOIGT, T.; SUBRAMANIAM, K. V.; SHAH, S. P. Nondestructive measurement of concrete strength gain by an ultrasonic wave reflection method. Materials and Structures, v. 36, n. 8, p. 507-514, 2003.

ALIG, I.; LELLINGER, D.; SULIMMA, J.; TADJBAKHSCH, S. Ultrasonic shear wave reflection method for measurements of the viscoelastic properties of polymer films. Review of Scientific Instruments, v. 68, n. 3, p. 1536-1542, 1997.

ALIG, I.; TADJBAKHSCH, S.; HADJICHRISTIDIS, N.; FLOUDAS, G. Order-to-disorder transition in a diblock copolymer studied at ultrasonic frequencies with a shear wave reflection technique. Europhysics Letters, v. 52, n. 3, p. 291-296, 2000.

ALIG, I.; TADJBAKHSCH, S.; ZOSEL, A. Comparison of ultrasonic shear wave and dynamic-mechanical measurements in acrylic-type copolymers. Journa of Polymer Science: Part B: Polymer Physics, v. 36, p. 1703-1711, 1998.

BADMAEV, B. B.; BUDAEV, O. R.; DEMBELOVA, T. S.; DAMINOV, B. B. Shear elasticity of fluids at low-frequent shear influence. Ultrasonics, v. 44, p. e1491-e1494, 2006.

BALASUBRAMANIAM, K.; SANKARAN, S.; RAJWADE, A. V. Ultrasonic nde rheological measurement tools for industrial process control. In: NDT.ORG. 16th WCNDT-World Conference on NDT. Montreal, Canada, 2004.

BALASUBRAMANIAM, K.; SHAH, V.; COSTLEY, R. D.; BOURDREAUX, G.; SINGH, J. P. High temperature ultrasonic sensor for the simultaneous measurement of viscosity and temperature of melts. Review of Scientific Instruments, v. 70, n. 12, p. 4618-4623, 1999.

BARLOW, A. J. Electrical measurement of the viscous and shear properties of liquids in the frequency range from $10^{4} \mathrm{c} / \mathrm{s}$ to $10^{8}$. Tese (Doutorado) University of London, 1959.

BARLOW, A. J.; HARRISON, G.; LAMB, J. Viscoelastic relaxation of polydimethylsiloxane liquids. Proceedings of the Royal Society of London. Series A, Mathematical and Physical Sciences, v. 282, n. 1389, p. 228-251, November 1964 .

BARLOW, A. J.; LAMB, J. The visco-elastic behaviour of lubricating oils under cyclic shearing stress. Proceedings of the Royal Society of London. Series A, Mathematical and Physical Sciences, v. 253, n. 1272, p. 52-69, November 1959. 
BARLOW, A. J.; SUBRAMANIAM, S. Experimental technique for the determination of the viscoelastic properties of liquids in the frequency range 5-75 mc/s. Brit. J. Appl. Phys., v. 17, p. 1201-1214, 1966.

BARNES, H. A.; HUTTON, J. F.; WALTERS, K. An Introduction to Rheology. Amsterdam: Elsevier Science B.V, 1989.

BEHRENDS, R.; KAATZE, U. A hihg frequency shear wave impedance spectrometer for low viscosity liquids. Measurement Science and Technology, v. 12 , p. 519-524, 2001.

BUCKIN, V.; KUDRYASHOV, E. Ultrasonic shear wave rheology of weak particle gels. Advances in Colloid and Interface Science, v. 89-90, p. 401-422, 2001.

BUIOCHI, F. Medição de viscosidade de líquidos por ultra-som. Tese (Doutorado) - Escola Politécnica da Universidade de São Paulo, 2000.

BUIOCHI., F.; ADAMOWSKI, J. C.; FURUKAWA, C. M. Measurement of viscosity using wave mode conversion. In: IEEE-UFFC. 1998 IEEE Ultrasonics Symposium. Sendai, Miyagi, Japan, 1998. v. 2, p. 1193-1196.

BUIOCHI, F.; FRANCO, E. E.; HIGUTI, R. T.; ADAMOWSKI, J. C. Viscosity measuring cell using ultrasonic wave mode conversion. Ferroelectrics, v. 333, p. 139-149, 2006.

BUIOCHI, F.; HIGUTI, R. T.; FURUKAWA, C. M.; SILVA, E. C. N. Medição de viscosidade de líquidos pelo método de múltiplas reflexções acústicas com conversão de modo. Revista Controle \& Automação, v. 14, n. 3, p. 330-337, 2003.

CHANDRASEKHAR, S. Propagation of elastic waves in liquid crystals. Proceedings of the Royal Society of London. Series A, Mathematical and Physical Sciences, v. 281, n. 1384, p. 92-98, August 1964.

COHEN-TEnOUdJ, F.; PARDEE, W. J.; TITTMAnN, B. R.; AHLBERG, L.; ELSLEY, R. K. A shear wave rheology sensor. IEEE Trans. Ultrason. Ferroelectr. Freq. Control, UFFC-34, n. 2, p. 263-269, 1987.

DIXON, S.; LANYON, B. Phase change measurement of ultrasonic shear waves on reflection from a curing epoxy system. J. Phys. D: Appl. Phys., v. 38, p. 4115-4125, 2005.

FRANCO, E. E. Análise do método de medição de viscosidade por ultra-som usando a reflexão de ondas de cisalhamento. Dissertação (Mestrado) - Escola Politécnica da Universidade de São Paulo, 2006.

FRANCO, E. E.; ADAMOWSKI, J. C.; BUIOCHI, F. Ultrasonic viscosity measurement using the shear-wave reflection coefficient with a novel signal processing technique. IEEE Transaction on Ultrasonics, Ferroelectrics and Frequency Control, v. 57, n. 5, p. 1133-1139, 2010. 
FRANCO, E. E.; ADAMOWSKI, J. C.; HIGUTI, R. T.; BUIOCHI, F. Viscosity measurement os newtonian liquids using the complex reflectiong coefficient. In: IEEE-UFFC. Proceedings of the 2006 IEEE Ultrasonic Symposium. Vancouver, Canada, 2006.

FRANCO, E. E.; ADAMOWSKI, J. C.; HIGUTI, R. T.; BUIOCHI, F. Analysis of an ultrasonic viscosity measurement cell with mode conversion. In: ICA - INTERNATIONAL COMMISSION FOR ACOUSTICS. Proceedings of the International Congresses on Ultrasonics - ICU 200\%. Viena, Austria, 2007.

FRANCO, E. E.; ADAMOWSKI, J. C.; HigUTI, R. T.; BUIOCHI, F. A simple maxwell based model in order to represent the frequency-dependent viscosity measured by ultrasound. In: IEEE-UFFC. Proceedings of the 2008 IEEE Ultrasonic Symposium. Beijing, 2008. p. 1905-1907.

FRANCO, E. E.; ADAMOWSKI, J. C.; HIGUTI, R. T.; BUIOCHI, F. Viscosity measurement of newtonian liquids using the complex reflection coefficient. IEEE Transaction on Ultrasonics, Ferroelectrics and Frequency Control, v. 55, n. 10, p. 2247-2253, 2008.

FRANCO, E. E.; ANDRADE, M. A. B.; HIGUTI, R. T.; ADAMOWSKI, J. C.; BUIOCHI, F. Acoustic transmission with mode conversion phenomenon. In: ABCM. Proceedings of COBEM 2005 - 18th International Congress of Mechanical Engineering. Ouro Preto, MG, Brasil, 2005.

FRANCO, E. E.; BUIOCHI, F. Análise do método de medição de viscosidade por ultra-som usando a reflexão de ondas de cisalhamento. Boletim Técnico da Escola Politécnica da USP, BT/PMR/0631, p. 15p, 2006.

FRENKEL, J. Kinetic Theory of Liquids. London: Oxford University Press, 1946.

GREENWOOD, M. S.; BAMBERGER, J. A. Measurement of viscosity and shear wave velocity of liquid or slurry for on-line process control. Ultrasonics, v. 39, p. 623-630, 2002.

HARRISON, G.; BARLOW, A. J. Dynamic viscosity measurement. Methods of Experimental Physics, v. 19, p. 137-178, 1981.

HIGUTI, R. T.; ADAMOWSKI, J. C. Ultrasonic densitometer using a multiple reflection technique. IEEE Transaction on Ultrasonics, Ferroelectrics and Frequency Control, v. 49, n. 9, p. 1260-1268, 2002.

HU, G.; XU, J.; AUNER, G. W.; SMOLINSKI, J.; YING, H. Digital phase detection approach and its application for aln dual-mode differential surface acoustic wave sensing. Sensors and Actuators B, v. 132, p. 272-279, 2008.

JAKOBY, B.; VELLEKOOP, M. J. Physical sensors for water-in-oil emulsions. Sensors and Actuators A, v. 110, n. 1-3, p. 28-32, 2004.

KASOLANG, S.; DWYER-JOYCE, R. S. Viscosity measurement in thin lubricant films using shear ultrasonic reflection. Proc. IMechE, v. 222, n. Part J, p. 423-429, 2008. 
KIEŁICZYŃSKI, P.; PAJEWSKI, W.; SZLAWESKI, M. Determination of the shear impedance of viscoelastic liquids using cylindrical piezoceramic resonators. IEEE Transactions on Ultrasonics, Ferroelectrics and Frequency Control, v. 50, n. 3, p. 230-236, March 2003.

KIEŁlCZYŃSKI, P.; PLOWIEC, R. Determination of the shear impedance of viscoelastic liquids using love and bleustein-gulyaev surface waves. The Journal of the Acoustical Society of America, v. 82, n. 2, p. 818-827, August 1989.

KINO, G. S. Acoustic waves: devices, imaging and analog signal processing. New Jersey: Prentice-Hall, 1987.

KIRK, F.; MARTINOTY, P. Ultrasonic investigation of anisotropic viscosities in a nematic liquid-crystal. Le Journal de Physique, v. 38, p. 3-9, 1976.

KULMYRZAEV, A.; MCCLEMENTS, D. J. High frequency dynamic shear rheology of honey. Journal of Food Engineering, v. 45, p. 219-224, 2000.

LONGIN, P. Y.; VERDIER, C.; PIAU, M. Dynamic shear rheology of high molecular weight polydimethylsiloxanes: comparison of rheometry and ultrasound. J. Non-Newtonian Fluid Mech., v. 76, p. 213-232, 1998.

MARTINOTY, P. Flexible polymers in a nematic medium: ultrasonic measurements. Le Journal de Physique, v. 44, p. L935-L945, December 1983.

MARTINOTY, P.; KIRK, F.; NAGAI, S.; CANDAU, S. Viscosity coefficients in the isotropic phase of a nematic liquid crystal. Le Journal de Physique, v. 38, p. 159-162, February 1977.

MASON, W. P. Measurement of viscosity and shear elasticity of liquids by means of a torsionally vibrating crystal. Proc. A.S.M.E., may 1947.

MASON, W. P.; BAKER, W. O.; MCSKIMIN, J. M.; HEISS, J. H. Measurement of shear elasticity and viscosity of liquids at ultrasonic frequencies. Physical Review, v. 75, n. 6, p. 936-946, 1949.

MCSKIMIN, H. J.; ANDREATCH, P. Measurement of dynamic shear impedance of low viscosity liquids at ultrasonic frequencies. The Journal of the Acoustical Society of America, v. 42, n. 1, p. 248-252, 1967.

MOORE, R. S.; MCSKIMIN, H. J.; GIENIEWSKI, C.; ANDREATCH, P. J. Dynamic mechanical properties of concentrated polystyrene solutions at $40 \mathrm{mhz}$. Journal of Chemical Physics, v. 47, n. 1, p. 3-9, july 1967.

MUKAI, K.; MAKINO, N.; USUI, H.; AMARI, T. Measurement of rheological properties for smectic-a liquid crystal by using ultrasonic rheometer and rotational viscometer. Progress in Organic Coating, v. 31, p. 179-184, 1997.

PRUGNE, C.; van Est, J.; CROS, B.; LÉVÊQUE, G.; ATTAL, J. Measurement of the viscosity of liquids by near-field acoustics. Measurement Science Technology, v. 9, p. 1894-1898, 1998. 
ROSEnBAUM, J. F. Bulk Acoustic Wave Theory and Devices. Norwood, MA: Artech House Inc., 1988.

SAGGIN, R.; COUPLAND, J. N. Oil viscosity measurement by ultrasonic reflectance. Journal of the American Oil Chemists' Society, v. 78, n. 5, p. 509-511, 2001.

SAGGIN, R.; COUPLAND, J. N. Rheology of xanthan/sucrose mixtures at ultrasonic frequencies. Journal of Food Engineering, v. 65, p. 49-53, 2004.

SAGGIN, R.; COUPLAND, J. N. Shear and longitudinal ultrasonic measurements of solid fat dispersions. Journal of the American Oil Chemists' Society, v. 18, n. 1, p. 27-31, 2004.

SHAH, V.; BALASUBRAMANIAM, K. Effect of viscosity on ultrasound wave reflection from a solid/liquid interface. Ultrasonics, v. 34, p. 817-824, 1996.

SHAH, V. V.; BALASUBRAMANIAM, K. Measuring newtonian viscosity from the phase of reflected ultrasonic shear wave. Ultrasonics, v. 38, p. 921-927, 2000.

SHEEN, S. H.; CHIEN, H. T.; RAPTIS, A. C. An in-line ultrasonic viscometer. Review of Progress in Quantitative Nondestructive Evaluation, v. 14, p. 1151-1158, 1995.

SHEPARD, C. L.; BURGHARD, B. J.; FRIESEL, M. A.; HILDEBRAND, B. P.; MOUA, X.; DIAZ, A. A.; ENDERLIN, C. W. Measurements of density and viscosity of one- and two-phase fluids with torsional waveguides. IEEE Transaction on Ultrasonics, Ferroelectrics and Frequency Control, v. 43, n. 3, p. 536-548, 1999.

SIMONETTI, F.; CAWLEY, P. Rapid low frequency measurement of the acoustic properties of solid viscoelastic materials. Review of Quantitative Nondestructive Evaluation, v. 23, p. 1107-1113, 2004.

SUN, Z.; VOIGT, T.; SHAH, S. P. Rheometric and ultrasonic investigations of viscoelastic properties of fresh portland cement pastes. Cement and Concrete Research, v. 36, n. 2, p. 278-287, 2006.

VALTORTA, D.; MAZZA, E. Measurement of rheological properties of soft biological tissue with a novel torsional resonator device. Rheological Acta, v. 45, p. 677-692, 2006.

VOGT, T.; LOWE, M.; CAWLEY, P. Cure monitoring using ultrasonic guided waves in wires. Revista Controle $\mathscr{E}$ Automação, v. 114, n. 3, p. 1303-1313, 2003.

WHORLOW, R. W. Rheological Techniques. New York: Ellis Horwood, 1992.

YONEDA, A.; ICHIHARA, M. Shear viscoelasticity of ultrasonic couplers by broadband reflectivity measurements. Journal Of Applied Physics, v. 97, p. 054901, 2005.

ZHANG, C.; CARON, J. J.; VETELINO, J. F. The bleustein-gulyaev wave for liquid sensing applications. Sensors and Actuators B, v. 76, p. 64-68, 2001. 